\title{
Valorising the Samad Late Iron Age
}

The Late Iron Age (LIA) in Central Oman is known from the eponymous site of Samad al-Shān as well as al-Moyassar (formerly al-Maysar), which teams from Bochum and Heidelberg investigated from 1977 to 1996 in twelve campaigns. The chronology of this little known period has evoked much controversy but although this contribution contains critical comments, these regard mostly smaller issues or details and there is a general unspoken agreement about the basic chronological issues. The present study adds both new and old unpublished documentation to the discussion. What follows includes a re-examination of the original documentation of M42 and M43 sites which confirms the excavators' chronology. New LIA sites are added. M. Mouton's attempted deconstruction of the existing chronology and his new combined definition of the PIR and Samad LIA assemblages rest on slight inconsistencies in the original al-Moyassar site report of 1981. Despite the spotty nature of our sources, Oman's latest prehistoric facies shows a distinctive character separate from that known principally in the United Arab Emirates (UAE).

Keywords: Samad, Late Iron Age, Central Oman, chronology, PIR, Samad LIA

\section{Paul Alan Yule}

Languages and Cultures of the

Near East, Semitic Studies,

Heidelberg University, Schulgasse 2, 69117 Heidelberg, Germany

e-mail: paul.yule@t-online.de

\section{Introduction}

An updating of recent literature with new information enables the historical value and importance of the Samad assemblage to emerge. Al-Moyassar North is the best-known place to study the beginning of the Samad Late Iron Age (LIA), but we hardly have a guarantee of a perfect and full reflection of the archaeological record. Over the years the discussion surrounding the LIA chronology and its attributes has evolved considerably. In what follows, old unpublished and new data both confirm some and redate certain other key contexts and artefact types. The content focuses on the original documentation of 1981 complemented by means of newly identified settlements - hitherto a weak point in our knowledge. A discussion of important aspects such as burial customs or gender studies lies outside our topic; and basic documentation, catalogues and site lists (esp. Yule \& Weisgerber 1999; Yule 2001a) or the present writer's obsolete absolute chronology published in 2001 do not need to be repeated.

\section{Nomenclature}

To prevent ambiguity in the chronological nomenclature, the present writer specifies the term 'Samad LIA' (Fig. 1). One reason is that $\mathrm{C}$. Phillips recently designated another different 'Late Iron Age' for south-east Arabia in the early first millennium $\mathrm{BCE}$, characterised by late Early Iron Age (EIA) pottery (2010: 72). As we shall see, the Samad LIA is not the sole archaeological facies of this age in this same region.

The mountainous point which spikes into the Strait of Hormuz and consists today of the UAE and Musandam, the northernmost part of the Sultanate of Oman, is designated as the 'Oman peninsula' (e.g. Mouton 2008: figs. 34). This term has established itself among our colleagues working in the UAE, but less so in Oman, where some officials consider it inappropriate. In authoritative sources published in Oman, such as the Encyclopedia of Oman, however, it is common usage. This designation overlaps spatially with 'Central Oman' (Potts 1992, I: 355, fig. 37). In its southernmost reaches, considering its basic shape 
PAUL A. YULE

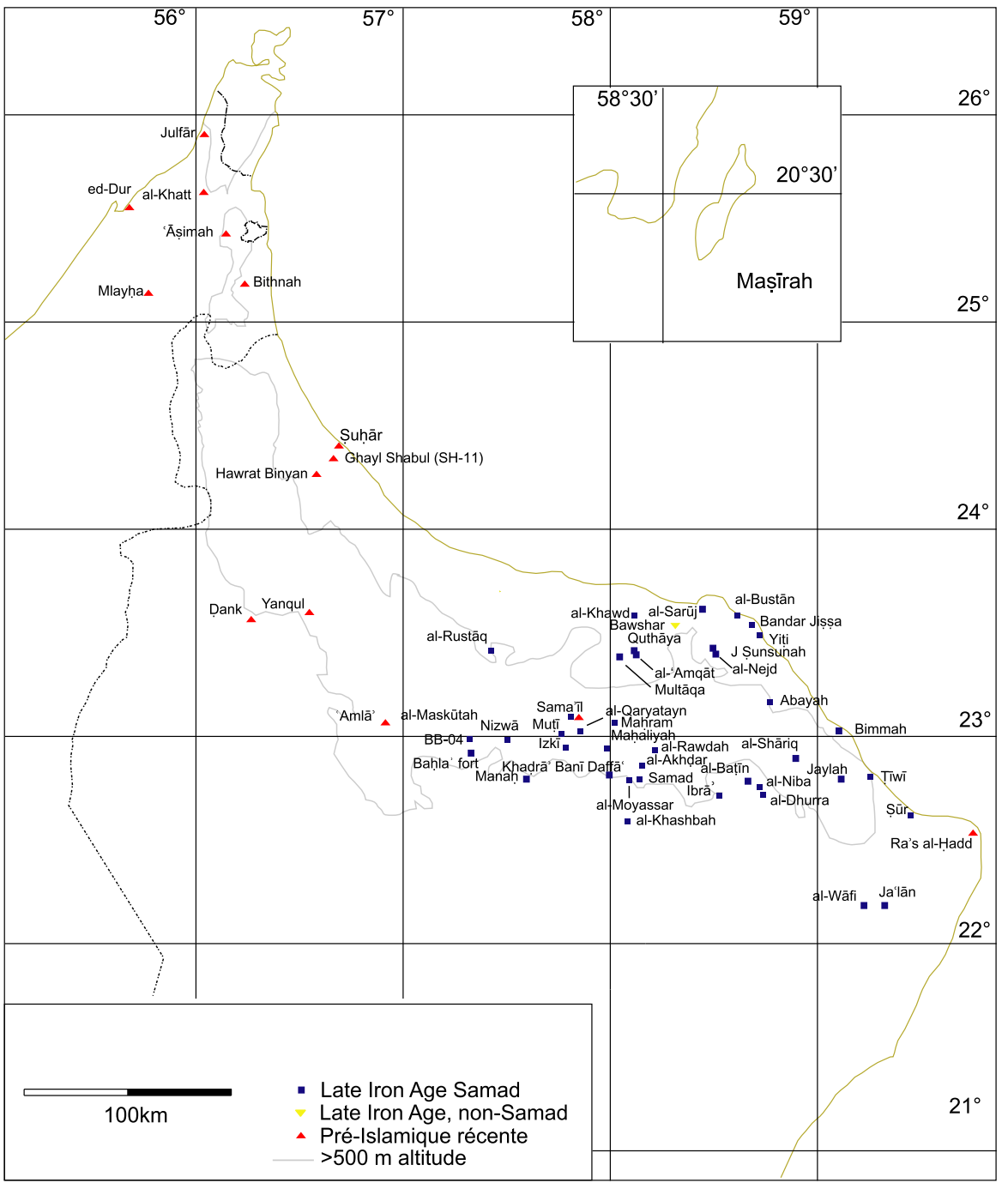

Fig. 1 .

Late Iron Age (LIA) sites in south-east Arabia. Seventy-five Samad LIA sites are known as opposed to eighteen of the PIR. Two rare LIA sites cannot be attributed to either.

south-eastern Arabia is strictly speaking not peninsular (Yule 2014: 14).

The jargon for archaeological materials also deserves a mention. For a variety of soft stones used to manufacture vessels, the term 'chlorite' has established itself generically in our literature, especially for vessels. At least six different groups of minerals have been identified in southeast Arabia deriving from the same altered ophiolitic rock (David 1991: 175-178). All can be collected in a single outcrop of only a few square metres. Thus, instead of giving the false impression (as if by means of instrumental analysis) of knowing exactly which mineral is meant, we refer here to the materials simply as 'soft stone'.
In 2014, for the sake of clarity and simplicity, the present writer adopted M. Mouton's nomenclature période préislamique récente or 'PIR' (replacing 'NLPC'), which he originated for UAE sites. Even though it has some script signs, especially on coins, for reasons of a broader understanding, the PIR is subsumed under the prehistoric LIA (Yule 2014: 16). Aramaic inscriptions found in eastern Arabia point to a limited literacy there. ${ }^{1}$ Since cultural anthropologists may feel uncomfortable with the term

1 See Healey \& Seray 1999: 2-3 for a discussion and a catalogue of texts; for the distribution of ancient Aramaic, see Macdonald 2010: 408. 
'Samad culture', the writer prefers the more neutral 'Samad assemblage'. Arabic place names are cited as they appear in the archaeological literature and we do not intend to Romanise them.

\section{State of research regarding the LIA}

From 1979 to 1982, the study group of the German Mining Museum led by Gerd Weisgerber, investigated thirdmillennium BCE copper-producing Magan/Makkan of Central Oman-a pioneering situation at that time in the archaeology of Oman. The team had no choice but to attempt to define the different periods ad hoc so as to date the mining and smelting relicts that they encountered. These included the LIA first identified at al-Akhdar, al-Bațīn, Khaḍrā' Ban̄̄ Daffā', al-Moyassar ${ }^{2}$ and Samad al-Shān, all in Oman's Sharqiyah province. A minor error in Weisgerber (1981: 236-238), which was corrected twenty years later (Yule 2001a, I: 389-391) but remained unnoticed, set off a chain reaction of misunderstandings regarding the dating of contexts in al-Moyassar (see below).

The number of studies which treat the Samad LIA is small (e.g. Weisgerber 1981; 1982; Yule 2001a; Kennet 2007; Schreiber 2007; Yule 2014: 47-76; Mouton \& Schiettecatte 2014: 78-99), the number of specialists is smaller still and smallest are the number of intact archaeological stratified contexts - the basis for chronology. Nonetheless, over the years authors have upheld the existence of the Samad LIA (Yule 2009: 75) despite attempts to marginalise it in Central Oman in favour of 'Hellenistic', 'Parthian' and 'Sasanian' nomenclature (Schreiber 2007: 64, 279; Yule 2014: 12; Kennet 2007: 86). Such appellatives from the middle and upper Gulf for archaeological periods in Central Oman still occur in the literature, although there is no real evidence for either historic group there, as opposed to the north where they are tried and true (Weisgerber 1982: 82). While there can be no question in a general way of Sasanian presence in centres, it is often

2 This place name was changed in $c .1995$ by royal decree as a result of its similarity to the word for gambling (maysir, root: $y s r)$. Little is known about the old Arabic maysir game. One version is played with arrows without points and feathers for the parts of the slaughtered camel. Its forbiddance in the Qur' an had little resonance in South Arabia (Arnold \& Sima 2011: 421). In Arabic 'gambling' is maysir, but the local population call the old place name 'al-Maysar' with the accent on the first syllable. The new euphemistic active participial place name 'al-Moyassar' (from 'yasār') means 'ease, comfort, prosperity or surplus'. difficult to bring substantiating archaeological evidence to bear. For example, at Izk̄̄ J. Wilkinson (1983: 182-183) established Iranian personal names ${ }^{3}$ in early Islamic fiqh documents and historic sources ('smoking gun' evidence), although no trace of this ethnos is attested archaeologically. Moreover, from 2002-2006 Schreiber searched systematically and found almost no evidence of their artefacts at the numerous sites he surveyed (2007: 65-66). In the UAE Mouton's archaeological 'PIR' displaced what was previously designated as historical 'Parthian-Sasanian Periods' for the region, with exceptions. Although they no doubt dwelled in number in the centres, the Sasanians are archaeologically almost transparent (contra Kennet 2007).

In south-east Arabia far more research is devoted especially to the EIA and still earlier periods than to the LIA. Moreover, the discussion culture regarding the Samad assemblage, and others in Oman as well, remains simple. It amounts to little more than firing off rival articles and lectures instead of less formal and more flexible means of true collegial interchange, such as forums or discussion. This combines with a certain spontaneity with regard to chronological notions and nomenclature, to judge, for example, from A. Avanzini's citing of P. Costa about the dating of old Izkī that it '....contains no significant EIA sites', and the reality of J. Schreiber having documented there 1041 archaeological find spots of all periods and 2000 EIA sherds (Schreiber 2007: 197; Yule, in press) in the core area (not the entire larger modern communal entity).

In the 1980s, at the beginning of the present author's own work on the LIA, it was essential to distinguish the attributes of what authors lumped together simply as the little-defined 'Iron Age', since a finer resolution was not always possible. Others use this term self-evidently to refer exclusively to the EIA, myopically ignoring the existence of a still later somehow 'decadent' prehistoric period, too late to be interesting for Near Eastern-trained archaeologists (but see the numerous writings of D.T. Potts). To contextualise, one can first parse the main attributes of the Wadi Suq, EIA and Samad LIA as a table (Yule \& Weisgerber 2001: 6-7, table 1; Yule 2001a, I: 14, table 2/1). Broad chronologically stylistic-typological rules hold for pottery, but equally for soft-stone vessels, beads and other find categories. There is a fair correspondence between a few EIA graves and their finds on the

3 It is a shame that Wilkinson did not say more about this population; in particular, their personal names would be a boon to onomastic studies. The sources that he cites are inaccessible to me. 
Table 1. Evolution of opinions regarding the Samad LIA chronology.

\begin{tabular}{|ll|}
\hline Samad LIA chronology & Source \\
\hline$c .300$ BCE & Weisgerber 1980: 98 \\
$3^{\text {rd }}-1^{\text {st }}$ cent. BCE & (Vogt) Weisgerber 1981: 243 \\
$>250$ BCE & Weisgerber 1982: 82 \\
$4^{\text {th }}-1^{\text {st }}$ cent. BCE & Vogt 1984: 277 \\
$>300$ BCE -1000 CE & Yule 2001, I: 164 \\
$1^{\text {st }}$ cent. BCE $-4^{\text {th }}$ cent. CE & Haerinck 2003: 302 \\
$3^{\text {rd }}$ cent. BCE $-4^{\text {th }} / 5^{\text {th }}$ cent. CE & Yule 2009: 79, 87 \\
$1^{\text {st }-3^{\text {rd }} \text { cent. CE at latest }}$ & Kennet 2007: 100 \\
mostly late BCE- $3^{\text {rd }}-4^{\text {th }}$ cent. & Schreiber 2007: 110, 301-302 \\
late BCE-300 CE? & present paper \\
\hline
\end{tabular}

Table 2. The LIA consists of two main assemblages, the PIR and Samad LIA.

\begin{tabular}{|ll|}
\hline Samad LIA late & PIR.D $c .225$ 1st quarter of 4th cent. CE \\
\hline 150-300 CE & PIR.C 1st-2nd cent. CE \\
Samad LIA early & PIR.B 2nd half of the 2nd cent. BCE 1st cent. CE \\
post 300 BCE & PIR.A 3rd cent. 1 st half of the 2nd cent. BCE \\
other LIA & late 1st mill. BCE/early 1st mill. CE \\
Early Iron Age & \\
$1300-300$ BCE & \\
\hline
\end{tabular}

one hand and those of the succeeding period at the Samad S10 cemetery on the other. Several single-period EIA sites provide a basis, especially for the pottery (see below). Briefly, excavated Samad LIA pottery contrasts with that of the preceding facies in terms of vessel shape, decoration and ware characteristics. Seldom painted, it shows pre-firing incised indented lines and puncture patterns, is softer than EIA wares and has a different temper. Significantly, glass beads become common at this time (see below). Most of our extant Samad LIA contexts are graves which also contain numerous iron, rarely copper-alloy arrowheads, daggers, long daggers, short swords and swordsor are thoroughly robbed.

Given the patchy nature of our sources, it is easy to doubt the chronological integrity of the rare archaeological facies, the Samad LIA: tomb robbing, the world's second oldest profession, skews our image of their original find inventories. Artefacts in precious metals rarely survive. These have been looted, as have the diagnostic roofs of many graves as building material, and thus cannot be used as evidence. Intact grave inventories (e.g. gr. Am3, Am5, $\mathrm{Bu} 8$ ) also contain a range of artefacts different than most, for example vitreous materials or leather, which oxidise and otherwise disappear once the grave roof is breached.

'Heirlooms' ('holdovers') found in Samad LIA contexts blur the differences between this period and those preceding it and have to be attributed to their respective periods of origin. The complexity of a burgeoning number of contexts and find-classes necessitates computer sorting in order to make a systematic chronology. Arrowheads, beads, razors, stone vessels and their lids, etc. originating ultimately from the third and second millennia occur in several LIA contexts (Yule 2001a, I: 100 n. 942; 207). It is necessary to model dated artefact assemblages linked to contexts and not simply to date intuitively according to 'development' without defining the artefactual types and classes from closed find inventories in single-period contexts.

Within the framework of the Oasis Project of Tübingen University, from 2000 to 2006 Schreiber conducted intensive survey in Central Oman, especially in Ibrā', Izkī, Nizwa, Țiwi and other find zones (esp. Schreiber 2007). This geographically broad survey was a logical counterpart to Yule's concentration on cemetery excavation, which focused on the Samad LIA. Schreiber's survey encompassed the metals periods. His thirteen (Samad, not PIR) LIA pottery wares (2007: 111-113) differ from the five that Yule described (Samad LIA ware classification: Yule 2014: 58, table 3). ${ }^{4}$ Yule's are based on the excavated grave pottery, Schreiber's on the settlement pottery from surveys. Although the present writer has not attempted a thoroughgoing comparison of the two, at least balsamarium and pilgrim bottle ware from the graves seem to be missing in Schreiber's ware catalogue. Moreover, the pottery in the al-Adbī LIA cemetery, which Schreiber identified as EIA, the present writer nonetheless classifies as Samad LIA (Yule, in press). Factors that connect the two classifications are pottery ware, shape, decoration and surface treatment. Schreiber names the following Samad LIA contexts: al-Khod, al-Dhurra near Ibrā', HD21, M34,

Table 3. The orientation of the long axes of the al-Fuwaydah graves $(\mathrm{n}=25)$.

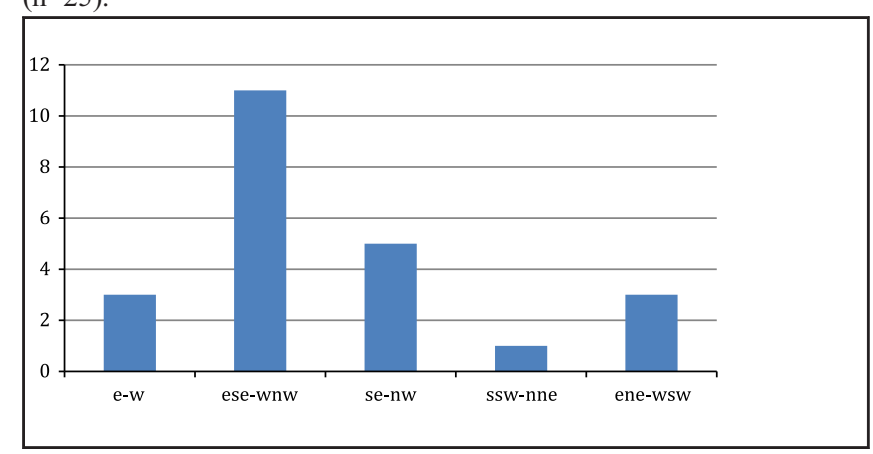

4 Contra Schreiber 2007: 112; 'We could not distinguish a typical Late Iron Age ware, rather, the Early Iron Age clay sources seem to have continued in use.' (translation P. Yule). 
M43, S1, S7 and LIA forts at al- 'Amqāt, Maḥram and Șūr (see below; Schreiber 2007: 64, 109, 110 n. 391). He interprets unstratified surface pottery to show fewer differences between the EIA and Samad LIA pottery shapes and decoration than Yule (2001) had determined.

Eight years had elapsed following the present author's last discussion of the Samad LIA chronology (held in 2006 as a talk, printed in 2009; see Kennet 2007: 100102) and an update followed. Main revisions included standing down from a radiocarbon-based chronology (already in Yule 2009: 74; 2014: 62), which dramatically shortens the time span for the Samad LIA from that suggested in 2001. Another is a summary of the development in the dating arguments, one of a series (see Table 1). In recent years a consensus has been established regarding the Samad LIA chronology. A catalogue of EIA and LIA sites reveals significant quantitative and chorological differences between the two, which require explanation (see below). The English language used in subsequent publications enhances reader comprehension. The sustained growth of the number of sites vindicates the honour of the sometimes battered Samad LIA (see Fig. 1; Yule 2014: 89-92). Although in recent years the Samad LIA absolute chronology has changed, there was no compelling reason to change its relative one. ${ }^{5}$

The present work suggests a time span for the Samad LIA from the late first millennium BCE to $300 \mathrm{CE}$. The updated Figure 32 sketches the few dated finds linked to the assemblage. The absolute dating of the Samad LIA dangles precariously on a single thermoluminescence dating of 130 $\pm 150 \mathrm{CE}$ for the fort al-Moyassar M34 (Yule 2014: 64; Wagner \& Yule, in press). Fortunately, chorological evidence and several artefactual dating correspondences also play a significant part. There is a dating gap between the available evidence to fix terminal EIA III contexts and that for the beginning of the Samad LIA. Despite a lack of evidence, colleagues unthinkingly raise the beginning date of the Samad LIA to bridge the gap with the find terminus of the better-dated EIA.

In 2009 a 'pool' in the image databank HeidICON was begun in order to complement the excavation documentation and argumentation of the Bochum and Heidelberg teams, which is dedicated to the archaeology of all periods in Oman (see http://heidicon.ub.uni-heidel-

5 The published excavations at al-Buhais and elsewhere, however, show classes that did not exist when the present author made his 2001 dating classification for the Wadi Suq and EIA finds (Yule \& Weisgerber, in press, a). berg.de/pool/oman). More than half of these c. 1200 images are unpublished or were originally published as drawings. Images from this archive complement the present text.

Another reinterpretation of the Samad LIA coincided in 2014 , in the same year as the present writer's, as a section of a book on the settlement archaeology of Arabia written by M. Mouton and J. Schiettecatte. Our colleague, Mouton, authored the section on south-east Arabia which is clear from an acquaintance with his publications on our period in the UAE of over twenty years. His study cites older English-language literature (Yule 1999a, 1999b, 2009 ) in our rapidly changing subject area and lags behind the present state of research (e.g. Yule 2013, 2014). Aside from Mouton requesting images for his study, unfortunately there was no other opportunity for interaction prior to publication. The selection of images in this part of the book results from the choices which the present author made without ever having seen Mouton's text or knowing his agenda.

Mouton attempts in principle and in details to deconstruct the Samad LIA relative and absolute chronologies first posed in 1981, 1982 and 2001 and revised in 2009. Most importantly he sees 'no need to retain this cultural distinction...', that is, between the Samad LIA and the PIR assemblages (Mouton \& Schiettecatte 2014: 80). Mouton never articulated the differences between the two and refers wrongly to the PIR finds from al-Fuwaydah cemetery as belonging to the 'Samad culture' (e.g. 2014: 79, fig. 63). ${ }^{6}$ Arguably, his new study could and should disambiguate the two assemblages.

Was LIA south-east Arabia culturally monolithic or homogeneous? Historical sources such as Tabari (Yule 2001b: 263 n. 34; 2014: 72) show that its early historic population was anything but ethnically and linguistically homogeneous. A good example is the twin towns that make up old Izkī, the once mutually hostile populations which derive from different parts of Arabia (Yule 2014: 29). Our main challenge is to articulate historical strands as accurately as possible, not forcibly to join them together.

\footnotetext{
6 Mouton writes that the present author has misunderstood this part of his text and he differentiates between the PIR and Samad LIA (correspondence 20/12/2014). Mouton 2008: 4 n. 3 vaguely mentions the distant Samad LIA, which is culturally different. But at that time the Samad LIA pottery was known only from some eight published plates (e.g. Vogt 1984: 280-281, figs. 12) and sparse ware descriptions.
} 
Mouton's views regarding the Samad LIA are made possible, on the one hand - as shall be contested - by his distance from its specialist literature, on the other by an arbitrary emphasis on certain sources but an exclusion of others. The German language in which the writer wrote is a barrier. Naturally, all can 'read' German, but few take the time. Just how distant is he from the relevant literature? Mouton never mentions the German Mining Museum and writes instead that his colleagues of many years are actually from Bochum (not Heidelberg) University (Mouton \& Schiettecatte 2014: 82). Moreover, the partly excavated al-Akhdiar cemetery is demoted to a 'single sherd from the Samad culture' (2014: 86; cf. Yule 2001a, I: 364; II: Taf. 465; 2014: 86; Yule \& Weisgerber, in press, b), and the salvage excavation at Khadrā' Ban̄ Daffa' 'as 'pottery...found on the surface of a cemetery' (Mouton \& Schiettecatte 2014: 87; cf. Yule 2001a, I: 383 384, II: Taf. 509-510; 2014: 87, 90). More disturbing is Mouton's opinion that after nine seasons of excavation mostly at Samad, the Bochum/Heidelberg teams recovered a total of only '37 skeletons for anthropological study' (Mouton \& Schiettecatte 2014: 82) although M. Kunter analysed 191, which form the basis for a gender and age analysis of Samad period individuals (Yule 2001a, I: 165 170, 209, 477-480; 2014: 66-67, 73). These skeletons also appear in the published grave drawings. ${ }^{7}$ Mouton ignores intact EIA single-period contexts such as the Lizq fort L1 and intact LIA contexts such as the graves at al'Amqāt, al-Bustān (Yule 2001a, I: 364-367, 371-377; II: Taf. 467-476, 482-500) and those from Samad cemetery S10. These suggest no gradual temporal transition, but on the contrary, mutually exclusive sequential EIA and LIA cultural assemblages (see below). An acquaintance with the present author's 2001 main excavation report and analysis evinces an argumentation for the relative chronology of the LIA which Mouton neither addresses, attempts to refute or evidently is aware of.

Numerous mechanical errors in Mouton's new study hinder comprehension and include erratic references for the phases and contexts (e.g. Mouton \& Schiettecatte 2014: p. 82: 'M7211' instead of M2711; p. 84: 'Șamad 10 cemetery' instead of Samad cemetery S10; 'grave 669' instead of grave S10669; p. 85: 'grave 11225' instead of grave S101125; 'STamad 30' instead of Samad cemetery S30; p. 86: 'Maysar 46' instead of al-Maysar M46; p. 89:

7 E.g. well-preserved and drawn for gr. Am1, Am3, Am5, Bu4Bu6, S1018, S1037, S101125, S101128, S101130, S101186, etc.- - four times his '37 skeletons'. 'grave 10' instead of grave Fu10, etc.). He rarely, if ever, mentions the Samad LIA codes: each site, grave and artefact class is referred to clearly and simply without lengthy descriptions, a standard operating archaeological procedure in most countries. Thus 'A1' designates class 1 axes and 'S2140' means grave 40 in Samad cemetery S21. The number of such errors causes one to ponder how serious Mouton is about his topic.

\section{Grave architecture}

Standing hut tombs in Central Oman are a classic feature in EIA, as opposed to northern Oman with its subterranean individual and collective tombs (Jasim 2012; Yule 2014: 35, fig. 13/3). Mouton writes about the continuity of funerary tradition in the form of burial cists (Mouton \& Schiettecatte 2014: 95) from the Bronze Age to the Samad LIA, unaware that the main EIA grave type temporally inbetween in Central Oman is the standing hut tomb (see below). These rarely survive because they were exposed to stone robbing. Considering the denser EIA population, far more EIA hut graves must once have existed in Central Oman than Samad LIA ones.

Different attributes characterise the latter graves. The long axis is usually south-east-north-west oriented. The graves of high-status owners are more exactly oriented in this direction. A sensitive indicator of grave date is a heavy roof and small retaining bar wall on top at the entrance (Fig. 2/1), but the Samad LIA shows at least four different known grave types, the appearance of which is conditioned by the local topography (Fig. 2/14): where there was no soil to excavate and it was not possible to dig into the bedrock, as at al-Jișșa, Izki and Tịwî̀, then the grave could only be built on the surface. Graves of the PIR facies are heterogeneous in form, size and their manner of construction and fall into ten types (Fig. 2/5 6; Haerinck 2001: 9 15). Those at 'Amlā'/al-Fuwaydah are more rustic in appearance than those at the main PIR sites - ed-Dur and Mlayha - and at first give the impression of being dissimilar and culturally separate from them. All of the Samad graves are rustic in appearance and are built of broken and wadi stones. Yet the al-Fuwaydah graves contrast with those of the Samad assemblage (and of other PIR sites). Lacking is the above-mentioned characteristic bar wall on the grave roof, and only five have the typical south-east-north-west orientation of the long grave axis. Since the roof constructions of the graves at alFuwaydah have rarely survived, it is difficult to determine a primary direction for the grave entrance, if there was one 


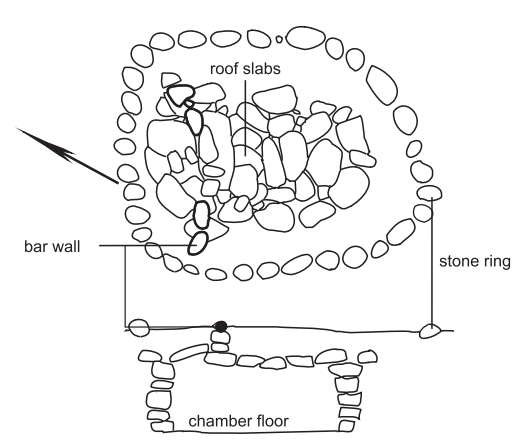

uppermost stones

1
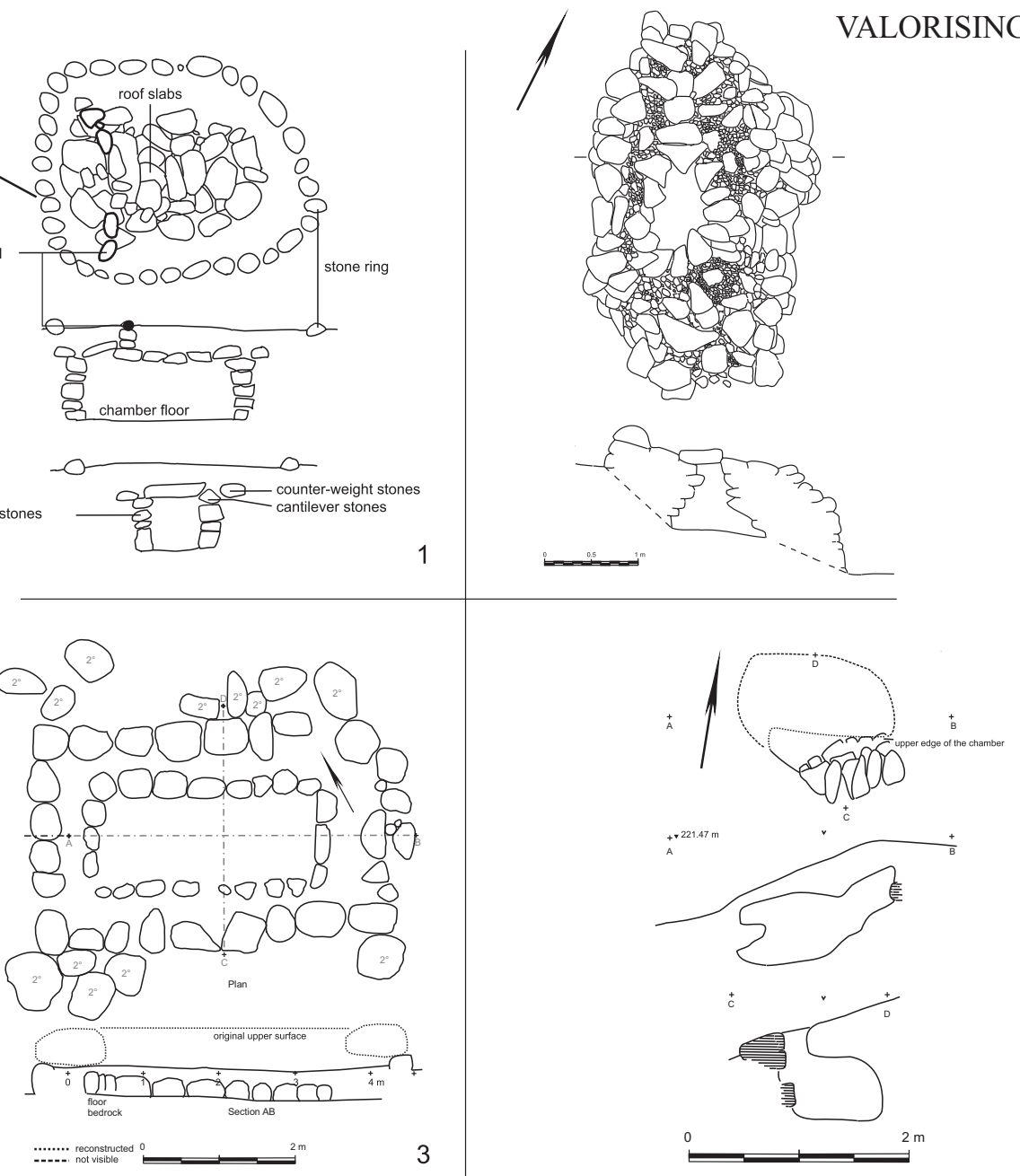

ran

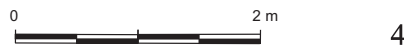

4
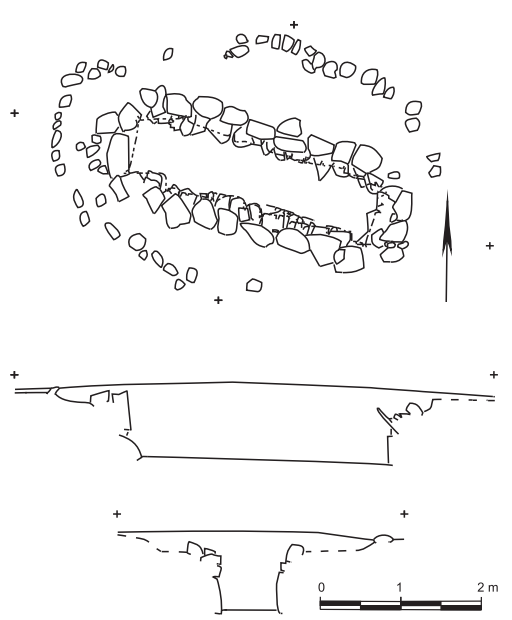

5
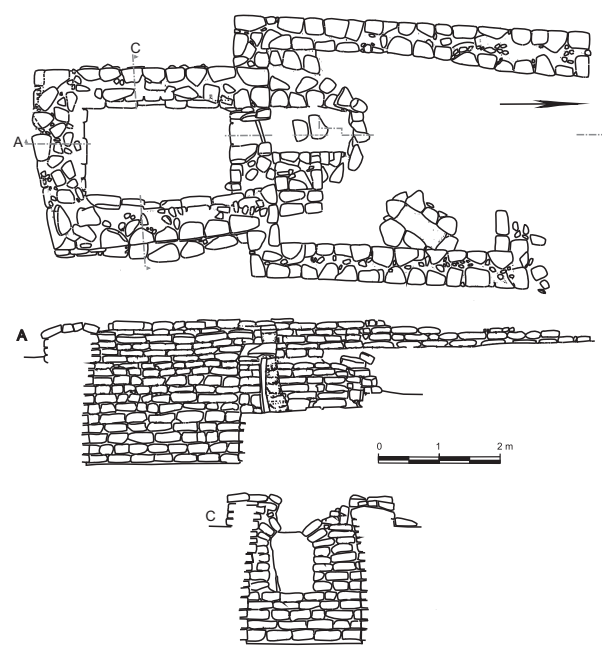

6

Fig. 2.

LIA graves: 1. Samad; 2. Tị̂̄ī TW406; 3. Izkīi; 4. al- 'Amqāt; 5. 'Amla'/al-Fuwaydah; 6. ed-Dur; most characteristic of the Samad LIA is a grave with a retaining wall on the grave roof. 
(Table 3). If not badly damaged, Samad graves can readily be distinguished from those of other periods, even prior to excavation.

\section{Pottery}

On nearly every single page of his 22-page reinterpretation of the Samad LIA, Mouton recapitulates that this period shows a gradual transition from the EIA in terms of pottery and stratigraphy (Mouton \& Schiettecatte 2014: 78$82,86,95,96)$; pottery decoration and shape are preserved from the EIA into the next period which rely on Schreiber's survey studies (e.g. 2010). Such generalisations skew the dating argument (see below) and stratigraphically are at best debatable, if not unsubstantiated.

Indeed, perhaps only two vessels known to the present author share the features of both periods (contra Schreiber 2007: 278). One is from EIA Bawshar grave B6 (= Yule 2009: 77 , fig. $2 / 4=2014: 38$, fig. $15 / 13$ ). It has a characteristically constricted EIA rim, but is fashioned from a finely levigated LIA balsamarium fabric and, like such vessels, is wheel-turned. A second bowl from an early LIA grave, S3004 made of Samad LIA 'standard ware' (Fig. 32/5; Yule 2001a, II: Taf. 426.1 = 2009: 77, fig. 2/3) has an EIA-looking constricted rim. A third probably early LIA grave context (S101116) contained an atypical (early?) jar in Samad ware and an EIA globular vase as well (Yule 2009: 77, fig. 2/1,2). These three cases are scant evidence for Mouton's hypothetical reconstruction; exceptions should not prove the rule. In fact, the main resemblance between the ceramics of the EIA and Samad LIA cited by our colleague comes down to the bare fact that most are handmade. ${ }^{8}$ Otherwise, decoration, shape and fabric contrast between the two periods, as a casual perusal of the pottery reveals (cf. Figs. 11 and 13 [EIA] with Fig. 15 [mostly LIA]). On the other hand, especially in the coarse ware, the chevron pattern and certain wavy lines in the settlement pottery present us with similarities between the two periods.

In his pottery discussion Mouton is aware of only a part of the published EIA and LIA material (see below). Notably missing in his argumentation is most of the material from the settlements M34, M42 and M43 (Yule 2001a, II: Taf. 519-525) as well as the Lizq fort, L1. The pottery of

8 It might prove useful to recheck the pottery from the Lizq L1 fort and confirm the method of manufacture, as Kroll himself suggests (2013: 175). Nowhere is more EIA pottery identified as wheel-turned than here. the latter EIA site was published in 1998 as a CD edited by himself and Carrez, but appeared more recently revised and updated into a more reader-friendly article form (Kroll 1998, 2013). EIA and Samad LIA pottery are also easily accessible in the image bank HeidICON/Oman (see above) and can be viewed by context or retrieved readily by means of the search words M34, M42, M43, M4302, M4304 or simply the word 'pottery'. These and below are a representative selection of the pottery from the EIA and LIA sites in the al-Moyassar plain, which complement and confirm the dates of that already published and shore up the dating system which Weisgerber advanced in 1981 and 1982 and who never changed his chorological dating for the falaj M46 (e.g. Weisgerber 2003). Subsequently, Yule added new excavated finds, unpublished thermoluminescence assays and refined the datings in al-Moyassar North (see below; 2001a, I: 390). ${ }^{9}$

Returning to the relation of PIR and Samad LIA assemblages, it must be pointed out here that LIA sites in the UAE in key cases are better preserved and better stratified than in neighbouring Central Oman. Owing to its stratified contexts the PIR chronological structure is more robust than the Samad LIA (Yule 2014: 66). The thought comes to mind: if the PIR and Samad LIA are as similar as Mouton suggests, why can one not simply date the fractious Samad LIA pottery by means of parallels with the betterknown PIR? He himself occasionally (e.g. Mouton \& Schiettecatte 2014: 80) refers to 'Samad Culture pottery' as an explanation, which indicates that he also sees a difference. There are two examples of Samad standard ware in his book (2014: 80, fig. 64), which could never be confused with PIR pottery (cf. Mouton 2008: figs. 10-20). Contrasting between the two assemblages are shape, decoration, technique (many PIR vessels are wheel-turned), surface treatment and the pottery fabric. The rarity of clear find-correspondences (see below) between the two LIA facies remains a basic fact for students of chronology, notwithstanding Mouton's explanation (Mouton \& Schiettecatte 2014: 80). Schreiber found few comparisons between the Samad LIA and PIR pottery (2007: 110, 170171).

Mouton describes the shared forms of wheel-turning of pilgrim bottles and balsamaria (the latter in céramique grise in the PIR nomenclature) found in the PIR and Samad LIA to be confusing (Mouton \& Schiettecatte 2014: 80),

\footnotetext{
9 In 1996 the present author turned over the original pottery ware slips and drawings from al-Moyassar M42 and M4302 to J. Schreiber for his dissertation.
} 
although they have been studied, assigned to classes and published in a straightforward manner (Yule 2001a, I: 62, 66, Abb. 5.4.3). Both consist of particular shapes that regularly occur in a characteristic ware although most balsamaria are identical between the two facies. Balsamaria need not be imports from northern to Central Oman, as Mouton states (Mouton \& Schiettecatte 2014: 85). The G7.6 balsamarium with its elaborate rim excavated from ed-Dur chantier $\mathrm{F}$ is a special case. Mouton considers a similar one from gr. S3015 (Fig. 32/16) to be an import from northern Oman (2014: 85; cf. Yule 2009: 78, fig. 3/ $8-9)$. A probable third example derives from grave BHS37 at al-Buhais from an LIA secondary burial (Jasim 2012: 119, fig. 147/6). All three are more likely imports from South Asia, although two are made of fine light red ware as well as one from ed-Dur in céramique grise, that is, balsamarium ware (Mouton 2008: 131, fig. 113/8), evidently a heterogeneous ware for large and small vessels. They are atypical of the pottery inventory of south-east Arabia. The other balsamaria from ed-Dur and Mlayha (and Samad) are in a fine and levigated céramique grise. Aside from these, there are few datable points of contact between the two archaeological assemblages (Yule 2001a, I: 62). In addition, Mouton described the writer's Samad LIA attributions as follows: '. . not based on exact comparisons' (Mouton \& Schiettecatte 2014: 81); one does not always have whole vessels for these, and certain contexts (e.g. Samad type graves) are attributed to the Samad LIA assemblage by virtue of the shapes known from large sherds and diagnostic fabrics found in situ, a standard archaeological practice. Oddly, grave forms appear not to be a means of dating for Mouton.

Mouton (2014: 81 n. 119) discards the dating comparison of pattern burnishing in early Samad LIA pottery by means of comparison with that from PIR.A Mlayha (citing Yule 2009: 79 [actually 78], fig. 3/1). One might preliminarily give him the benefit of the doubt since Mouton is an expert on PIR, but his hesitancy would be more clearly understandable to readers if more of the PIR settlement pottery were published in usable photographs and with descriptions (cf. Rutten 2009).

Neither Samad LIA finds nor such sites are in evidence in the UAE (D. Kennet, personal communication), but two PIR sites exist in Central Oman: the 'Amlä'/al-Fuwaydah cemetery and the Sama'îl/al-Bārūn̄ grave inventory, Bar1 (Yule 2001a, I: 401-402; II: Taf. 534-535). In 1997 the systematic excavation of twenty-five PIR graves in al-Fuwaydah caused a major event in our research since it yielded a find inventory in Oman, which had little to do typologically with the Samad assemblage but shared close relations to the PIR known in classical form from sites in the UAE (Yule 1999a: 119-196). During the excavation of al-Fuwaydah the best and only means of dating its finds resulted from comparisons from grave inventories at Mlayha and ed-Dur (1999a: 142). Stone vessels and pottery link them to the PIR.A and PIR.B phases with which Mouton concurs (Mouton \& Schiettecatte 2014: 90). Although the difference between the PIR and Samad LIA is simple, no colleagues explicitly and publicly confirmed this bipartite classification. It is difficult to compare the two assemblages because of the many and various dissimilarities in the different publications.

The pottery, stone bowl and arrowheads - sixteen finds in all-from the Sama'il Barl inventory all find comparisons with those at late PIR sites (Yule 2001a, I: $156 \mathrm{nn}$. 1474 and 1475; 2014: 57, fig. 30; 65, fig. 34) but not with those of the Samad LIA: G8var storage vessels in 'sandy ware' are most numerous in the third and fourth centuries in terms of the PIR. Mouton's type D arrowheads (cf. the P11 class) occur from the first to fourth century (Mouton 1990: 101, table 9; Yule 2001a, I: 156). His dating criteria (horse spout, stone bowl, arrowheads) are hardly explained, and neither are they really stylistic or typological. The argumentation is superficial: the mere presence of a drinking service in two contexts (Mouton \& Schiettecatte 2014: 91) hardly suffices to prove contemporaneity without at least rudimentary articulation. The arrowheads in the Bar1 inventory certainly do not belong to Mouton's type C, as stated (2014: 91), but nicely fit his type D (cf. Fig. 5/C and class P11). Even if some of his comparisons vaguely match some of the Samad LIA finds, all of his types span more than one phase and none are limited to a single one. He dates this grave inventory to the first or second century CE (=PIR.C; 2014: 91-92). All of the finds, however, seem later and better fit the rare PIR.D (Table 2; see below; Yule 2001a, I: 156 n. 1473).

\section{Soft-stone vessels}

With the end of the EIA a new series of undecorated stone vessels replaces the EIA shapes and decorative systems. Soft stone is used, that is, pale calcite, grey chlorite, serpentine and steatite (see above for the nomenclature). The Samad and PIR assemblages correlate respectively with different shape preferences. Mouton has typologised these for his PIR.A to PIR.C sites (PIR.A: Mouton 2008: 56-57, figs. 25, 26; B: 77-78, figs. 44-45; C: 113-115, figs. 9395; D: 156-160). Chronologically relevant 'beehive'- 
PAUL A. YULE
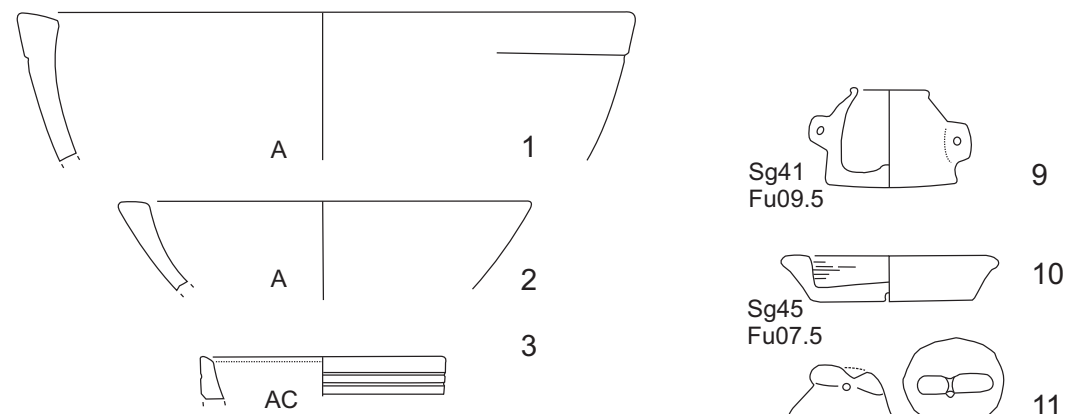

$$
\text { Fu07.5 }
$$

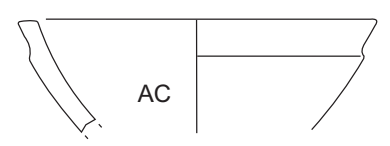

4
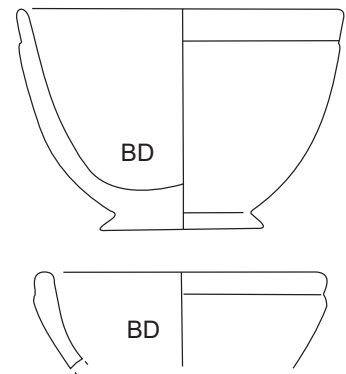

5
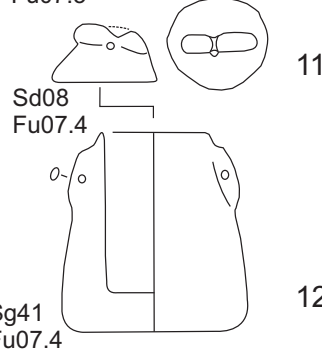

12

Fu07.

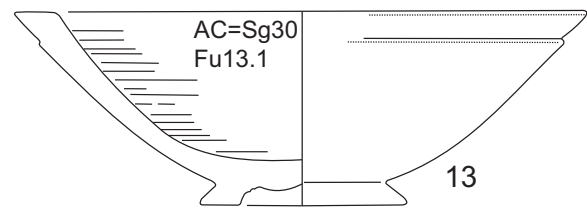

6
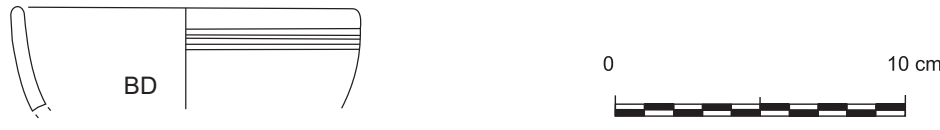

7

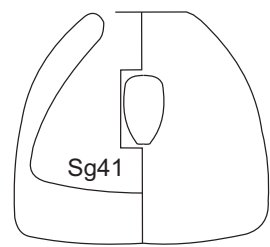

8

Fig. 3 .

Soft-stone vessels and a lid from Mlayha (left) and 'Amla'/al-Fuwaydah (right). Apart from one exception, the forms are identical. The letters next to the vessels give Mouton's types (e.g. 'A'). Those that begin with Sg belong to Yule's classifications. The Fu abbreviation gives the grave followed by the find number at al-Fuywaydah.

shaped vessels range from the late first millennium BCE up to c.400 CE (Hassel 1997: 245). These stone vessels from South Arabia and northern Oman contrast with those of the Samad LIA artefactual assemblage, first in terms of shape. At PIR sites such 'chlorite' vessels are numerous, and Mlayḥa yielded 272 fragments of which 105 have recognisable profiles (Mouton 2008: 156). Mouton describes the majority of these to be 'finis au tour'. Corroborating contemporary examples from Central Oman have clear lathe-turning traces inside, as indicated (e.g. Fig. 4/ $1,8)$ on others they have been polished away. It is not possi- ble to know exactly which vessels Mouton counted, but they are more numerous than the twenty of LIA date which teams in Oman have registered over the years (Fig. 4).

There are enough vessels with a constricted rim typical of the EIA in PIR.A to venture that these later examples are possibly not all EIA holdovers (Altstücke) (Fig. 3/1 6) and perhaps continue in production into the earliest LIA. The key to this problem lies in the integrity of the early PIR levels in Mlayha and ed-Dur where they occur stratified in some numbers (see below). Stone vessels in EIA shape and decoration occur in Samad LIA graves (e.g. 

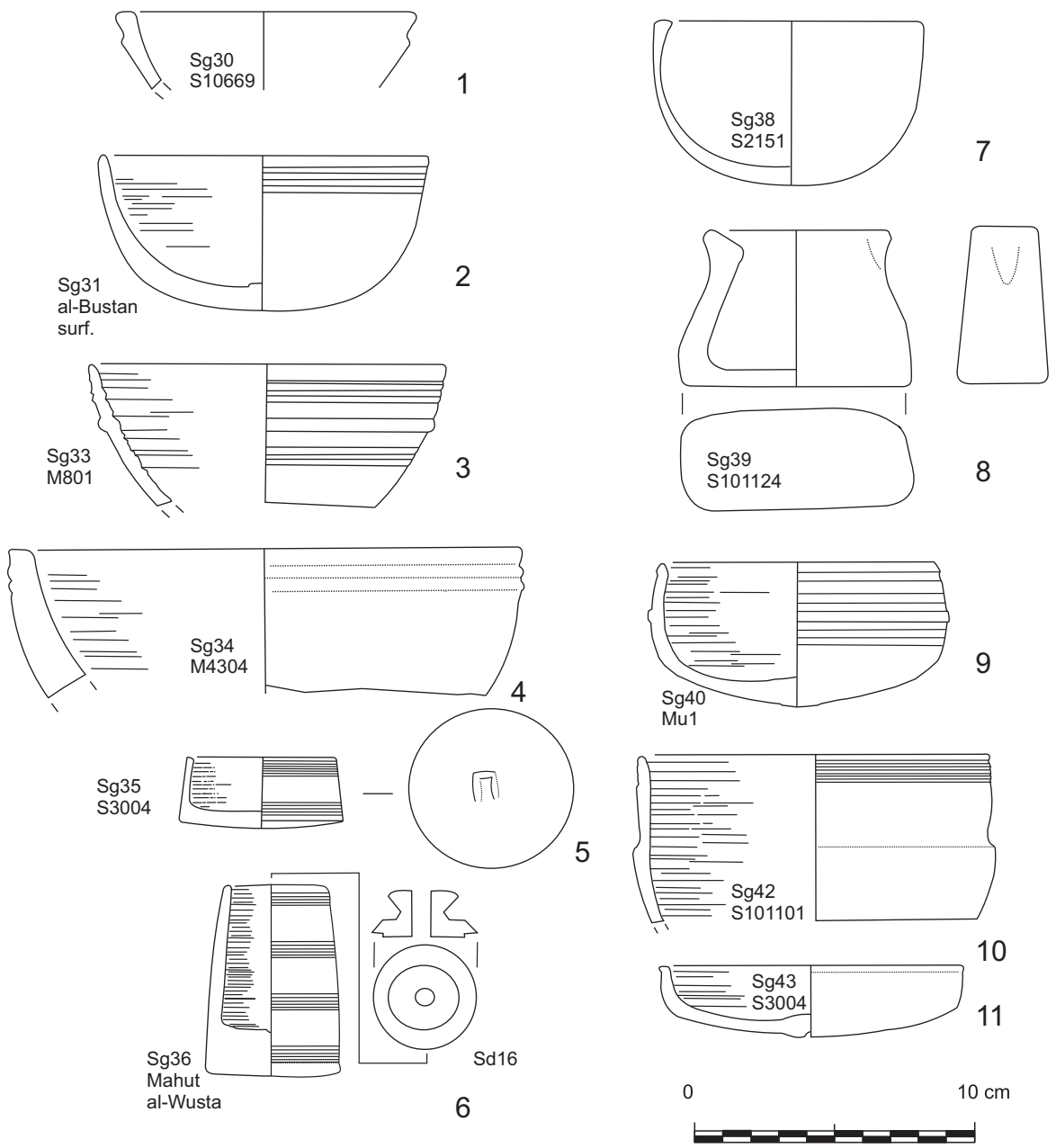

Fig. 4.

Soft-stone vessel classes from Samad LIA contexts. No. 1 derives from an EIA grave. Sg is short for 'stone vessel'. Sg39 (calcite) is foreign to the Samad LIA.

M2717/2, M2720/1, S101130, etc.). The Samad LIA graves Bu5, S10815, S10823, S101101 and S101110 also contain Umm an-Nar and Wadi Suq stone vessels (holdovers), among the diagnostic LIA finds, which should not confuse us.

Holdovers from one period to another can occur for different reasons anywhere in the archaeological world and the transmission of the artefactual record to posterity is imperfect, as all post-processualists would agree. With regard to his redating (e.g. the pottery of M34, see below) Mouton should not overestimate the range of our dating method. It is as if Mālik bin Fahm had once said apodictically to his potters, 'I am tired of EIA pottery, from today on you will not make EIA pottery, but only LIA shapes and fabrics. Be careful on which hill you discard them'. Analogously, in Europe occasional finds (e.g. of Neolithic and
Bronze Age) in early medieval contexts happen routinely without provoking attempts to redate the medieval period.

A lathe-turned stone bowl (class Sg34, Fig. 4/4) from the M4304 excavation in al-Moyassar also belongs to the Samad LIA assemblage (cf. Yule 2014: 40, fig. 16/17 etc. for comparanda) which Mouton (Mouton \& Schiettecatte 2014: 86) assigns to PIR.A (late third-mid-second century CE) but without giving his source, which turns out to be his type AD (Mouton 2008: 156, fig. 25/7). In his dissertation, however, Mouton dated this type earlier, to the second half of the first millennium BCE. Unfortunately, no context in Mlayha is mentioned for the two examples that he cites. This vessel class belongs to the earliest known finds found in a Samad LIA context and offers only a weak reason to raise the terminus of the Samad LIA in absolute years. 
PAUL A. YULE
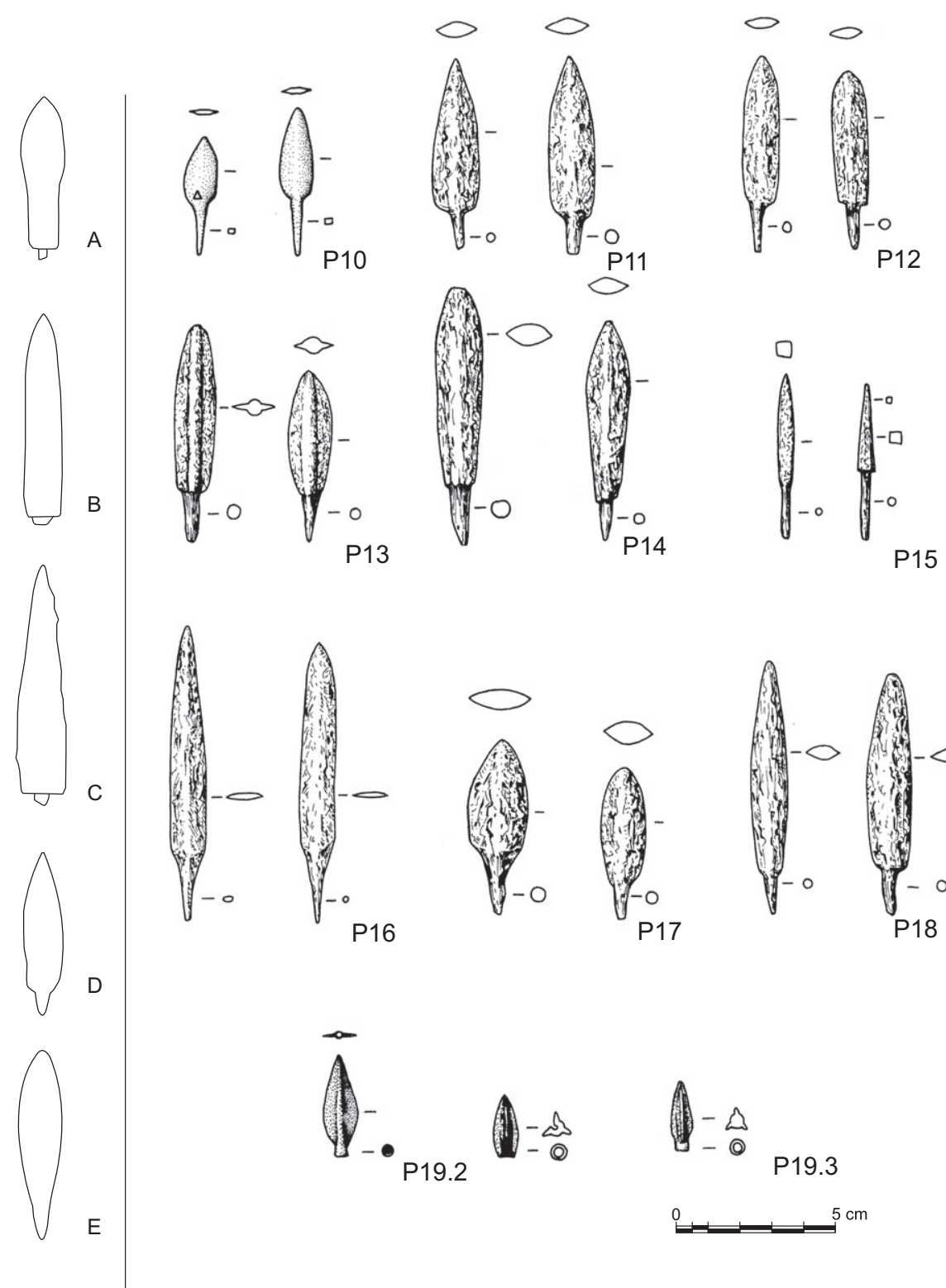

Fig. 5 .

LIA arrowheads, left (A-D): ed-Dur and Mlayha; right: Samad LIA except P19.2 and P19.3. Class P10 occurs in both EIA II and Samad LIA contexts.

'Beehive' vessels have not been reported in Central Oman. If we compare the stone vessels from northern (Fig. 3) and Central Oman (Fig. 4), the differences far outweigh the similarities.

\section{Metalwork}

The graves from Central Oman yielded significantly different metal finds than those from northern Oman. In the first, Samad men's graves contain more and different weapons, especially arrowheads, presumably a reflection of the political situation there. The PIR cemetery at al-Fuwaydah is the only exception: although culturally linked with the north, it lies in Central Oman. Gr. Fu12 there contained at least three swords and some forty-five whole or fragmentary arrowheads. The large number is, however, more than a single person would require. It probably contained two burials not represented in the skeletal remains (Yule 1999a: 142-143).

Arrowheads have been a hope for chronologists since they became available for study. B. Vogt's comparison, made years ago, between those of the Samad LIA and 


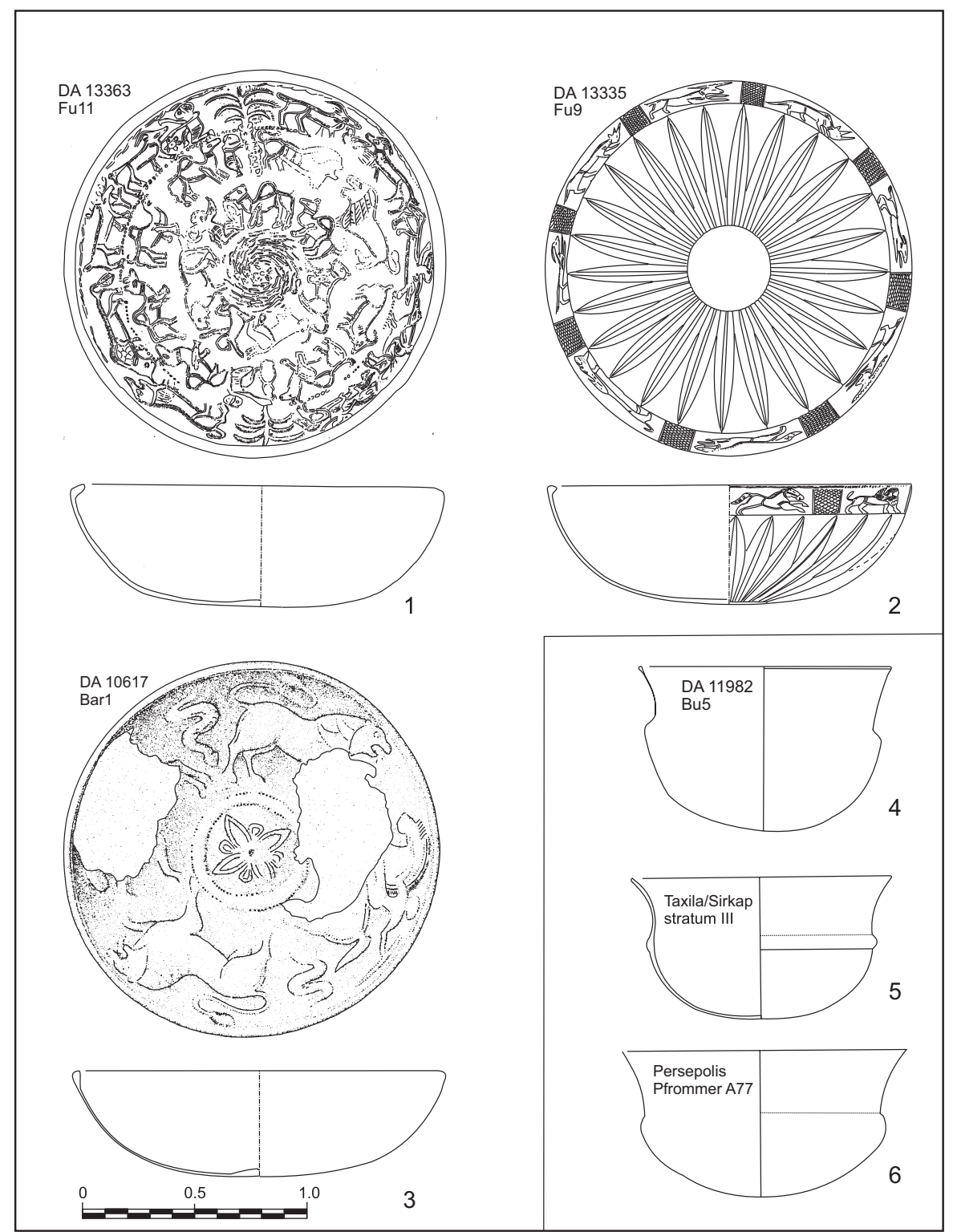

Fig. 6 .

Metal bowls: 1. al-Fuwaydah gr. Fu11; 2. gr. Fu9; 3. Sama'1̄l grave inventory Bar1; 4. al-Bustan gr. Bu5; 5. Taxila Sirkap strat. III; 6. Persepolis; nos. 4-6, of the MeOB11 class, have been compared with those of the Achaemenid period, but most examples post-date this period.

those from the 'garrison headquarters' and 'Treasury' of Achaemenid Persepolis (e.g. 1984: 284, fig. $5=$ Schmidt 1957: pl. 76/4 6) is understandable but suggests the limits of such artefactual comparisons for the chronology: despite a perceived similarity, his two groups are not contemporary with each other. Achaemenid ones predate the Samad LIA arrowheads; aside from the fact that the dating of the 'garrison headquarters' is uncertain, this context need not exactly date the arrowheads which it contained. First, the vast majority there are bronze (Schmidt 1957: 97) and a small minority thereof are iron. Second, they are booty collected from outside Persepolis, which makes the provenance and its dating unpredictable. Third, Persepolis contains numerous early Achaemenid objects, for example, coins. The final word is that no finds there post-date Alexander's vandalism of $331 \mathrm{BCE}-100$ to 300 years prior to the beginning of the Samad LIA. This comparison is unsuited for the Samad LIA.

Arrowheads from the PIR sites (621) and the Samad LIA (795 mostly excavated from Samad and al-Moyassar graves) are in large part intuitively contemporary but differ significantly from each other in their form. Mouton's 
simple sketched types without sections present a hurdle for those inclined to compare for themselves. ${ }^{10}$ The tangs are implausibly short compared to other published arrowheads (Fig. 5). On the other hand, few of the arrowheads drawn from Central Oman have been restored and the exactness of the sections varies with the degree of their swelling as a result of oxidation. Moreover, the act of drawing corroded iron arrowheads is an interpretation. The upshot is that with few exceptions, the arrowheads from Central Oman poorly and rarely match those from ed-Dur and Mlayha. Figure 5 juxtaposes the PIR typology and Samad LIA classification. Systematic comparison (Yule 2001a, I: 103-104) reveals that some P14 arrowheads can be assigned to Mouton types A1 and E, some P12 arrowheads to type B, some P11 to type D and some P13 to his type E. The greatest difference lies between arrowhead types $\mathrm{A}$ and $\mathrm{C}$, which have no correspondences in Central Oman as suggested in Figure 5. The closest shape matches are with the (rare) class P11 and type D arrowheads. Since most of Mouton's examples are unpublished we have to trust his typology that we can neither doubt nor confirm. Three-bladed arrowheads occur in northern, not Central Oman.

Some fourteen LIA bowls, mostly fashioned from copper alloy, have been published mostly from PIR sites, which are interesting owing to their ornate decoration (Yule 2001b: 281, table 2). A few cannot be firmly attributed by means of iconographic type or stylistic parallels to either assemblage (e.g. Yule 2001a, I: 382, Abb. $13.2=$ 2001b: 261, fig. 3). Similarly, another decorated bowl from the PIR gr. Fu9 finds no parallels except its body form (Fig. 6/2). Independently from each other, Yule and Mouton identified one group, the examples of which share stylistic and typological features (e.g. Fig. 6/1). Commonly held attributes are the circular zonal composition, the choice of motives and the vessel shape, a phiale form with a thickened or tipped-in rim. Most show lathe finishing of the vessel form itself. Mouton assigns 'the decorated bronze bowls in the graves' from al-Fuwaydah to his PIR.B (Mouton \& Schiettecatte 2014: 90), which agrees with the present writer's proposed dating for Figure 6/1 (Yule 1999a: 142), but only for one and not all from the al-Fuwaydah graves. A third attractive PIR phiale from Sama' '11/al-Bārūn̄̄/ grave inventory Bar1 (Fig. 6/3) seems later in date to judge from its accompanying pottery, for want of a better method of dating (Yule 2001b: 281). Its

10 Mouton (1990: 94, fig. 4) shows better drawings and more types: A1 and A2 arrowheads. decorative system also brings to mind Sasanian hunting bowls without compositional concentric zones. The thick stylisation of the horse heads and brush manes bring to mind those of Sasanian rider reliefs at Naqsh-i Rustam. Clearly it is not possible to date this phiale by means of stylistic comparison with other extant decorated examples from PIR contexts. ${ }^{11}$

In contrast, one vessel shape from the Samad LIA, which inevitably brings to mind innumerable dated EIA shapes from Iran (St John Simpson, personal communication), never occurs in PIR context: the MeOB11 class of open bowls with a concave rim and carinated shoulder (Fig. 6/4). Nor is it lathe-turned like those just discussed. It might be locally produced. Several examples deriving from Samad LIA contexts have come to light. M. Pfrommer (1987: 55, Taf. 62) points out with numerous examples that such vessels post-date the Achaemenid period. ${ }^{12}$ In Egypt some continue to c.325 BCE. Later examples exist in Samad LIA contexts and at Taxila/Sirkap of the fourth century BCE (Fig. 6/5,6; Marshall 1951, I: 103, 157 , no. 6 [not mentioned in the text]). Examples of this class outside Oman occurring in situ admittedly pre-date my suggested dating bracket for the Samad LIA, a compromise which the present author can tolerate for now.

Years of concentrated searching failed to turn up evidence for a LIA copper production in Central Oman (Yule 2001a, I: 193; 2014: 68). For a time we believed we could find LIA copper production in al-Rākī, but this context instead yielded EIA II pottery (Benoist 2000: 291-292; Magee 2003: 5-6). Mouton picks up the observation (Mouton \& Schiettecatte 2014: 97) that there is still no evidence for ore exploitation and little for metal working at the Samad LIA sites. He cites an article by Ploquin, Orzachowsky and Briand (1999: [179, 186 pl. 3] without page numbers and omitting the co-authors) to explain a vessel with a horizontal hole in the base excavated from Mlayha as a possible portable forge used by an itinerant smith. In fact, the French archaeometallurgists advanced only a guess regarding the identification of this large vessel, and an unconvincing one at that, based on the drain, which they mistook for a tuyère. First, there was no trace of metal in the vessel (1999: 179) and second, the burning

11 Other iconographically related decorated bowls (DA 27062DA 27070) recently came to light far to the south, in al-Juba near al-Mahut, al-Wūsta Governorate, reportedly looted from a single grave context. These are currently being restored and are under study.

12 The drawing technique of all three of these vessels is heterogeneous and therefore must be checked against the originals. 
traces hardly correspond to what one would expect from a forge. Moreover, Mouton states their carefully advanced hypothesis as proven. He then cites similar vessels in gr. S10825 and S3001 and suggests that all are in the same 'pale ware with abundant mineral temper'. Among the difficulties here is that, in fact, the two Samad vats are 'dusky red' (7.5YR 3/4) and 'red' (2.5YR 5/6) —not 'pale red'in surface hue. Nor do they show traces of burning or metal. Except for the balsamaria, no one has systematically compared the Samad and PIR wares; ware similarities still form an exotic topic. Rare similar wares are proven only from PIR vessels from the Sama'il grave inventory, Barl and Mlayha (Yule 2001a, I: 156 n. 1474). Six unpublished drain-hole vats from Samad have no burning traces whatever and thus cannot explain the obscure history of iron production in LIA south-east Arabia.

\section{Beads}

Of the pre-Islamic beads that have been studied (Yule 2001a, I: 100, 102), 4290 derive from graves of the Samad LIA. Despite robbing, most contain beads but few contain entire necklaces in situ (e.g. gr. Am3, S21104, S3004). Several Samad LIA graves show beads that differ in all aspects from those of other periods. On the other hand, holdovers are difficult to identify with certainty, especially those fashioned from hard stones such as carnelian. Biconical and spherical beads have been in production from the third millennium to the present day. Certain beads, such as discs in soft stone and shell, remained in production from the Hafit period to the LIA.

Glass beads in EIA contexts are extremely rare but comprise the most common bead material in the following period (Yule 2001a, I: 97, 100). Beads in artificial materials such as frit are already numerous in EIA III contexts, for example from Rumaylah (2001a, I: 97). Typical Samad LIA catalogued beads are made of opaque glass in a depressed spherical form. They range considerably in size with a large number of miniatures, so small that they cannot be consistently formed into the same shape. Among the glass beads olive green, greyish brown, red, orangeochre and dark green dominate and find few outside comparisons.

De Waele's discussion of the beads excavated from edDur and their foreign relations (2007) omits any mention of LIA beads from Central Oman-a sure sign of dissimilarity between the two assemblages, which counters Mouton's proposed mutual similarity. The only bead classes shared between the two facies are non-diagnostic, for example - once more-biconical and spherical beads in semi-precious stone. The main advantage in studying the Samad LIA beads is that 111 were examined by means of physical methods to determine their composition and structure (cf. Tables 4 and 5). Rarely is there a problem with the gemmological identification of hard stones such as agate; artificial materials are far more challenging. A comparison of preliminary field identifications and

Table 4. The materials of the Samad LIA beads $(\mathrm{n}=4290)$.

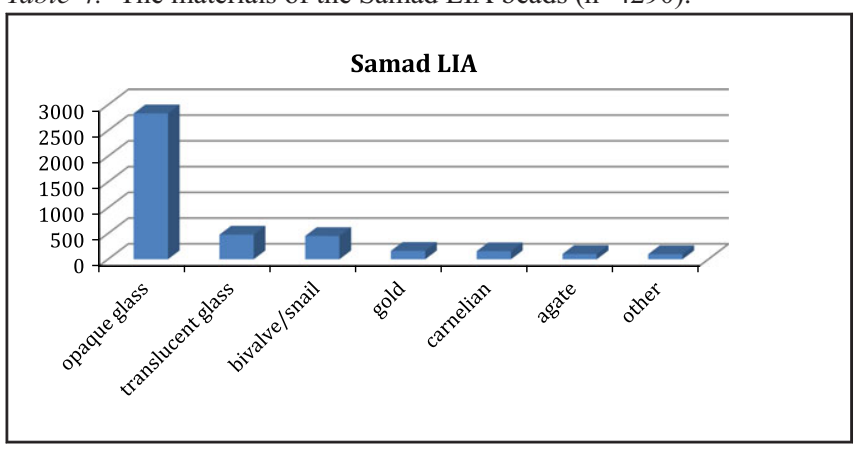

Table 5. The materials of the PIR beads from ed-Dur ( $\mathrm{n}=1228)$.

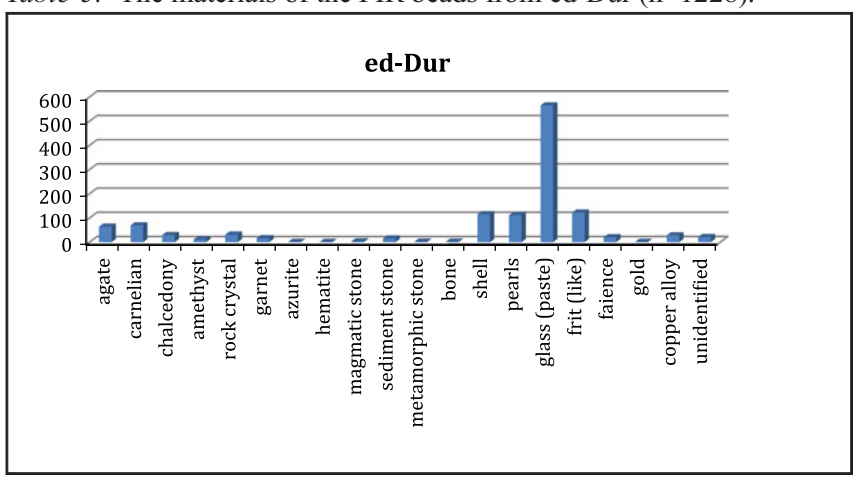

Table 6. Selected field identifications (left) compared to laboratory analyses of beads from Samad LIA sites (right).

\begin{tabular}{|ll|}
\hline Field & Lab \\
\hline soapstone & chlorite \\
frit & glazed frit \\
calcite? & clay \\
glass & glazed frit \\
basalt? & amphibolite chlorite \\
glass & natrium calcium glass \\
glass & lead glass \\
frit & smectite \\
shell? & calcite \\
glass & glass/frit \\
marble? & serpentine \\
obsidian & garnet \\
\hline
\end{tabular}


PAUL A. YULE

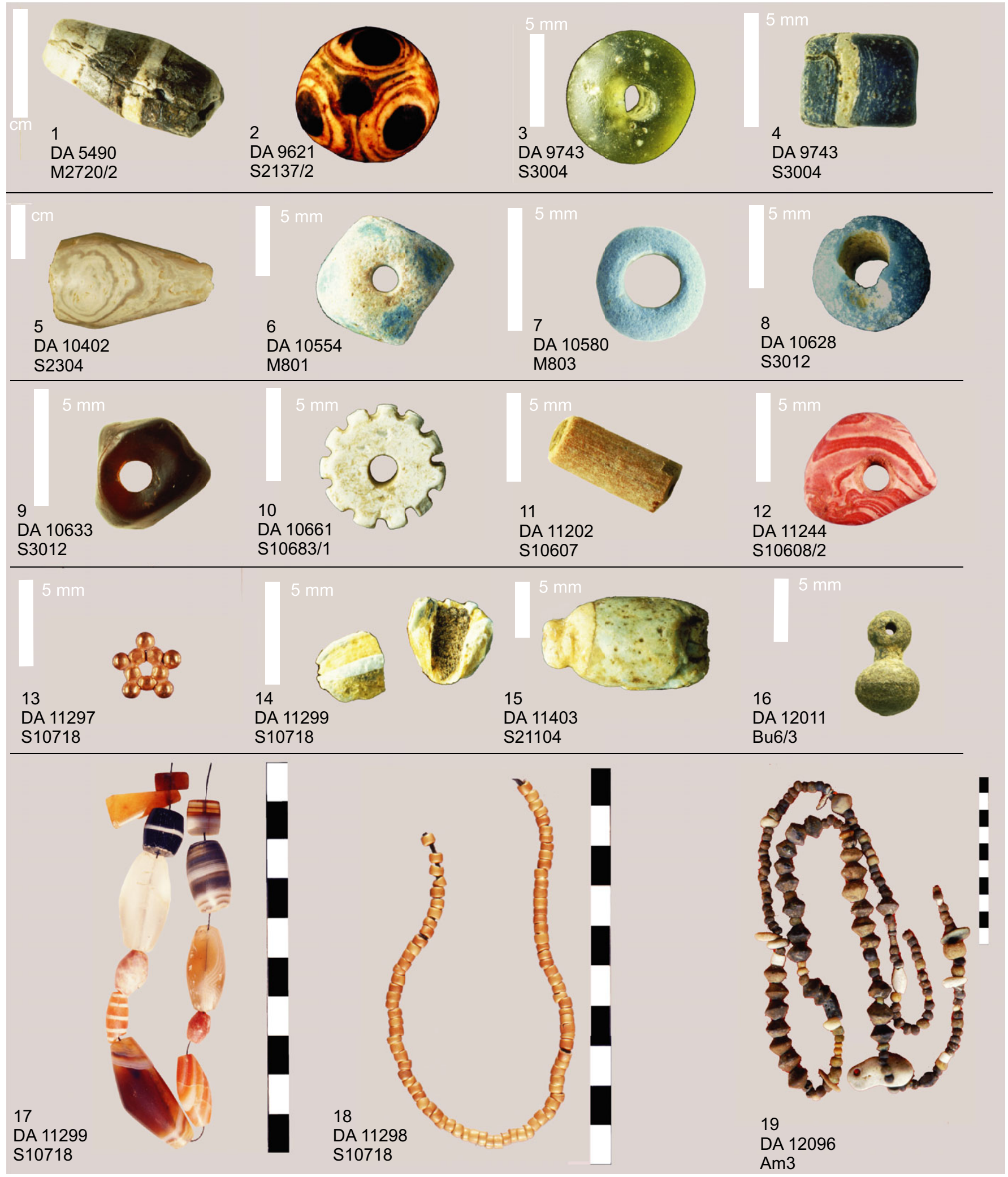

Fig. 7.

Selected beads and necklaces from Samad LIA contexts. 
archaeometric measurement showed numerous discrepancies (Table 6; Rösch 1994; Rösch et al. 1997).

The selection strategy for the laboratory analyses of the beads from Central Oman was simple: the present writer selected both the most typical and difficult bead materials, usually artificial materials. A casual perusal of those from ed-Dur and the Samad LIA sites reveals some contrasts resulting from the identification techniques used: Samad LIA beads are produced from natrium lime glass (Fig. 7/3,4), natrium lime magnesium glass (Fig. 7/ 8) and lead silicate glass (Fig. 7/11; Rösch 1994: ii). For the production, kiln temperatures reached between $900^{\circ}$ and $1100^{\circ} \mathrm{C}$. Certain beads are obvious holdovers looted from third-millennium contexts such as a smectite bead with a gold band. Sandwich glass (Fig. 7/1,4) and microbeads with fine contrasting lines are probably South Asian products, to judge from sub-recent and recent comparisons. The best correspondences with South Asian beads are the material glass and certain shapes, such as beads with collared ends (Fig. 7/15). Beads made of precious metals could as easily derive from Iran, the West or South Asia (Fig. 7/13,16,18), but close outside comparisons are rare. The beads in a given grave and from a given necklace are often heterogeneous in the shape, material and size combinations (Fig. 7/19). Exotic examples include cornerless cubes (Fig. 7/6), Egyptian blue (Fig. 7/7) and garnet from Sri Lanka (Fig. 7/9). Even badly corroded glass beads reveal the glassmakers' virtuosity (Fig. 7/14), better viewed in a few restored examples (Fig. 7/2).

\section{Stratigraphy}

The EIA and LIA stratigraphic continuity that Mouton emphasises (Mouton \& Schiettecatte 2014: 95 n. 212) rests implicitly on the assumption that survey finds somehow tend to come from single-period occupations. In addition, Schreiber mentioned one unexcavated site at Ibrä (2007: 277), which Mouton believes shows this continuity. His chronological belief might be admissible, but there is neither a cross-sectional view nor were the observations made with the help of excavation. Numerous spatially mixed EIA and Samad LIA burials at Mahaliya could be taken as evidence for an intimate connection between the two populations, but excavation is required to make the point stick chorologically or stratigraphically. Obviously, LIA populations succeeded earlier ones within a given archaeological zone, as at Izkī for example. Recent research there, however, shows that the position of the
Samad LIA settlement and its cemetery differs from those of their EIA predecessors. This suggests not just a simple transition from EIA to LIA but rather a reoccupation at spatially slightly different sites. Despite recent disturbances there in 2004-2011 as a result of construction, the main Samad LIA settlement appears to lie mostly beneath the Ya'āriba period fort, Huṣn Izkī (Schreiber 2007: 169; Yule, in press). The present writer excavated debris from this settlement just outside the northern wall of al-Yemen town. LIA pottery finds and the LIA graves in al-Adbi strengthen this dating. The close proximity of the settlement to this cemetery, on the other side of the wadi, supports this idea.

\section{Imported materials and products}

Origin of the 'imported' finds

Mouton writes that during the LIA as a result of communication between northern and Central Oman, '... material from the Mleiha assemblage [are] found in deposits of the Samad culture, such as iron weaponry, ([p. 79] fig. 63), wheel-turned chlorite vessels and a few ceramic vessels' (Mouton \& Schiettecatte 2014: 78). The present writer would parry these three points and instead pose the question, why must the finds in Samad graves be from Mlayha and not vice versa? Arguments are lacking for both positions. Up to now only a single unequivocally PIR find in a Samad LIA context has come to light (see Fig. 19). The production might also have taken place in both areas by means of itinerant craftsmen, as Mouton suggests for metalworking (2014: 97). We may focus here more pointedly on the different find manifestations, beginning with grave architecture.

During the LIA, northern Oman had far more imports from the Mediterranean region than did Central Oman (Haerinck 2001; Yule 2014: 67-69). For reasons still little understood, in the LIA Central Oman remained a trade backwater compared with the towns in northern Oman, Mlayha and ed-Dur. One reason is its low population spread over a vast area, where one would expect the greatest LIA population density, the Bātinah, which Kennet is currently surveying, one of several archaeologists to do so since 1972. Since the beginning of research this large area has remained an archaeological terra incognita.

Another reason for a lack of LIA imports in Central Oman is a lack of trade exports, especially copper (see below). The probable main imports have not survived and were so ordinary they were never mentioned in the 


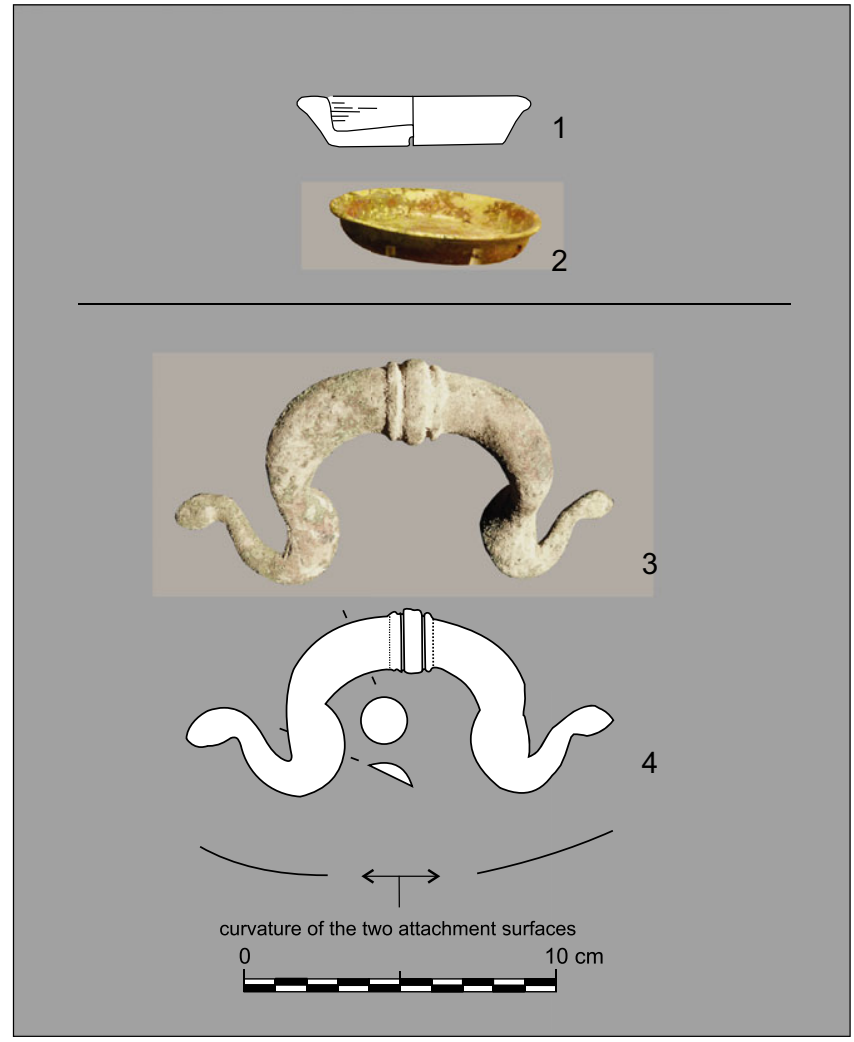

Fig. 8 .

Imports to Central Oman are rare and difficult to identify. The only two possible ones from the mare nostrum are a lathe-turned stone dish (1) with a close match from Pompeii (2) and a brace of Roman bronze handles $(3,4)$. Only one such handle is shown.

succeeding literate period-livestock, agricultural produce and wool textiles. Other main imports appear to be implements of copper alloy and iron, as well as the raw materials, including raw glass (Yule 2014: 67-69). Even if South Asia undisputedly was always a major exporter for iron and beads, during the LIA exact parallels are rare between the two regions. We have to consider the possibility of other less tangible trade partners.

Two imports to Central Oman have escaped notice, the first excavated from al-Fuwaydah gr. Fu7 (Fig. 8/1). The Sg45 class lathe-turned stone dish (DA 13346, diameter: $8.5 \mathrm{~cm}$ ) finds its closest parallel from Pompeii, destroyed in $79 \mathrm{CE}$ (Fig. 8/2). The similarity lies in the shape, the lathe-turning method of manufacture and the size.

A more obvious import is a pair of solid ornate handles with snake-head terminals from a squat open bowl-part of a collection that locals gleaned from tombs (Fig. 8/3 4) reportedly around Mahut, al-Wūsta Governorate. Such ornate handles often terminate in animal-head finials, and protomes such as snakes or sea horses are of Hellenistic origin, which came again into fashion in Augustan times. In his typology of Roman bronze vessels Eggers somewhat arbitrarily distributed these basins within his type numbers 98, 99 and 100 (1951: 168-169; also 1949-50: 90-91, Taf. 1a. 4b Tabelle I-II; cf. in summary Wielowiejski 1985: 199-200, 282-284, Taf. 13/1-2; 14). Examples have come to light in Germany, but in Pompeii thirtyfive have been reported (Kenner 1961: 132-133, Abb. 72/ 5; Deimel 1982: 163, Taf. 20/1). The early dating mainly to the first century $\mathrm{CE}$ is also confirmed by finds in rich Germanic graves ${ }^{13}$ that are dated to the later first to early second century. The initially popular snakes lose their attractiveness. When resumed in the later imperial period, other animal heads are portrayed. Thus, the handles in question are to be dated in all probability to the first century CE.

\section{Settlements and triliths}

Unfortunately, the archaeology of the Samad LIA is still basically funerary. Few dwellings have been publishedor ones such as M43, Mahaliya, S1 and S3017b only minimally — but others are known (see below). The settlements Samad S1 and Tịwi TW0002 were unique until 2014 when better preserved ones at al-Nejd and J. Șunsunah (see below) revealed the presence of a different survival strategy than living in the oasis and retreating into the strongholds during Bedouin razias. The LIA hadher settlers, however, must have actually dwelled in the bigger settlements. Curiously, in contrast to the others, M43 was not walled. The mainly fortified settlements that lay out-

Table 7. The pottery from different site M43 mounds. The earliest, M4302, dates to the EIA; the others contain pottery of the Samad LIA.

\begin{tabular}{|c|c|c|}
\hline Site & $\begin{array}{l}\text { References in } \\
\text { Weisgerber 1981; Yule \& } \\
\text { Weisgerber 1999; Yule 2001a, II }\end{array}$ & Period \\
\hline M4302 & 1999: 110, fig 11 & EIA \\
\hline M4304 & $\begin{array}{l}\text { 1981: 236, Abb. } \\
\text { 78/1-7; 79/10-19; 2001, II: } \\
\text { Taf 524/1, 4, 7, 10, }\end{array}$ & LIA \\
\hline M4323 & 2001: Taf. $524 / 2$ & LIA \\
\hline M4325 & 1981: 237, Abb. 79.12, 14, 15. & LIA \\
\hline M4329 & 2001: Taf. 524/13? & LIA \\
\hline M4330 & 2001: Taf. 524/9 & LIA \\
\hline M4332 & 2001: Taf. $524 / 2,3,5,6,11,13$ & LIA \\
\hline
\end{tabular}

13 From the so-called prince graves of the Lübsow stage; see tables I-II in Eggers 1949-50: 108-110. 
side continually reoccupied oases, which over the centuries were repeatedly re-excavated (Table 7), have survived for posterity. Such defensive settlements were essential during the LIA in Central Oman and, because of raiders, indicate a hostile survival environment, but they need not be purely local to this part of Oman. These settlements contrast sharply in size, organisation and building techniques with those in northern Oman. An ideal natural defence is a steep-walled plateau, higher on one side and concave, where water can collect.

Despite the depredations of recent building operations and ubiquitous stone robbing, the best preserved such fortified settlements are Wadi Mahram/Qariyat al-Saih, Ibrā' I0052, TTiwi site TW0002 and that on the J. Șunsunah. All four give an idea of the settlement and its dwellings (size, shape, etc.). Casemate construction occurs in the fortifications at Mahaliya, M34, J. Șunsunah, TW0002 and Qariyat al-Saih. It seems characteristic of this period's architecture.

Triliths - rows of standing stones combined with rows of parallel ash pits - are obviously not settlements but religious monuments (Dostal 1968; al-Shahrrī 1991; Yule 2013: 18-21; Harrower, Senn \& McCorriston, in press: 148). They suffer from a lack of radiocarbon dating, but they have been estimated to date from $400 \mathrm{BCE}$ to $300 \mathrm{CE}$ - somewhat similar to that of the Samad assemblage. Several years ago the present author abandoned the idea of a connection between the Samad LIA and the triliths. Even if they were brought from south-west Arabia to south-east Arabia, no pattern of transmission could be demonstrated. Dostal's theory that they are associated with Mehri speakers on the basis of their historic spatial distribution still has merit (Yule 2013: 20-21, 28), and is more viable than a transmission by means of Azd migratory tribes.

\section{Chorology of al-Moyassar North}

Part of the archaeologist's toolkit merited by decades of central European research and publication-'chorology' or 'horizontal stratigraphy' - also has proved its value in geological, biological and environmental studies. Even if it seems rare in English-language literature, it is a common tool especially in studies of Central European prehistoric and early historic cemeteries. ${ }^{14}$ Chorology refers to the study of causal relations between spatial expansion pat-

14 Paradoxically, Wheeler's old classic Archaeology from the Earth (1954) does not even mention it. For a history of horizontal stratigraphy, see Eggert 2001: 222-247. terns occurring within a particular space, large or small. In this study it has two applications: first, for the local chronology of al-Moyassar North and second, for the distribution of all EIA sites in relation to those of the LIA in south-east Arabia (see below). Despite the lack of deeply stratified sites in Central Oman, the chorological development at al-Moyassar North should not be under-rated to trace the transition from EIA to LIA in the area. It may perhaps even be a better indicator than conventional stratigraphy since later building does not disturb earlier settlement. Settlement in the al-Moyassar plain is the gift of the subterranean falaj channel, M46. Weisgerber established his well-known chronological 'falaj mechanics' here: ${ }^{15}$ at an elevation of $555 \mathrm{~m}$ just west of the wadi lies the EIA settlement M42 where the story of falaj M46 begins.

Sites lying to the south are lower in elevation than this; for example, today's village lies $1200 \mathrm{~m}$ downslope at $539 \mathrm{~m}$ in elevation. As the Iron Age water table began to drop, concomitantly the floor of the falaj had to be deepened, ${ }^{16}$ quite an investment in time and labour. Water exploitation lowered the water table resulting in repeated falaj floor-deepening; the distance between the falaj roof and floor was as much as $8 \mathrm{~m} .{ }^{17}$ Over-exploitation caused the fall and a new falaj was dug beneath the older M46, the latter serving as a receptacle for the backfill of its successor. Since it was easier to move the settlement than dig deep wells and hoist the water from them, the LIA dwellers moved their settlement downhill to the south of M42 (Figs. 9, 10) which generated settlement M43, then still made possible by falaj M46. Here evidence is lacking for dams or wells. Lines of recent falaj construction shafts are visible to the south of the present-day garden, but to little avail because after being finished the aflāj soon exhausted the aquifer through over-irrigation.

15 E.g. Weisgerber 1981: 247, Abb. 93; Weisgerber 2003: 76, fig. 28; Yule 2014: 44, fig. 19. In his last article on the aftajj Weisgerber wrote that falaj M46 predated M42 (2003: 79), which seems illogical since there is no earlier settlement as its raison d'être and it was built to supply this settlement.

16 Uncertain of this causal relationship Mouton writes, 'probably due to the lowering of the water table that supplied it' (Mouton \& Schiettecatte 2014: 86). If it is not due to the lowering of the water table as Weisgerber stated in 1981, what could otherwise be the cause? No falaj, no agriculture.

17 Mouton (Mouton \& Schiettecatte 2014: 86) cites Weisgerber as '3 m'. Cf. Weisgerber 1981: 246 'bis zu 8 m'. One cross section shows over $6 \mathrm{~m}$ distance between the lowest falaj and the earth above, disturbed by earlier falaj building (Weisgerber 2003: 74, fig. 24). 
PAUL A. YULE

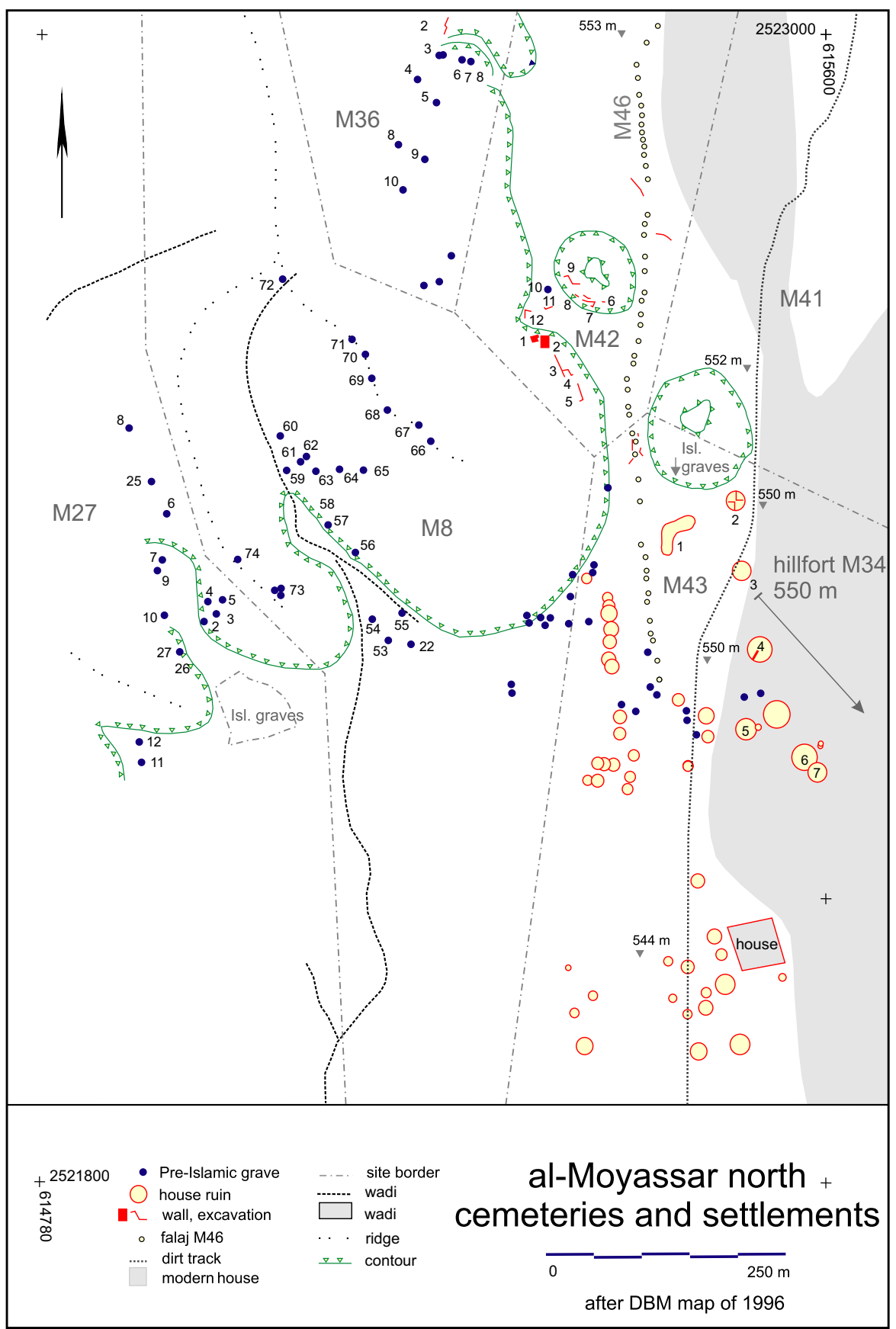

Fig. 9.

Sites at al-Moyassar North; few of the southern mounds of site M43 are numbered or are preserved.

From 1996 to 2005 (he writes '1989') during falaj deepening, Weisgerber observed the repeated lowering of the falaj to accommodate the unabated drop in the water table -in all some $15 \mathrm{~m}$ since the EIA settlement M42. The new falaj excavations stretched some $580 \mathrm{~m}$ to the south, with M42 left of centre. First the old falaj section near M42 was sketched (Yule \& Weisgerber 1999: 101, fig. 3) and later photographs were taken of the three deeper-lying, later, successive falaj generations of M46 in the middle of the M43 settlement scatter (Weisgerber 2003: 74-75, 


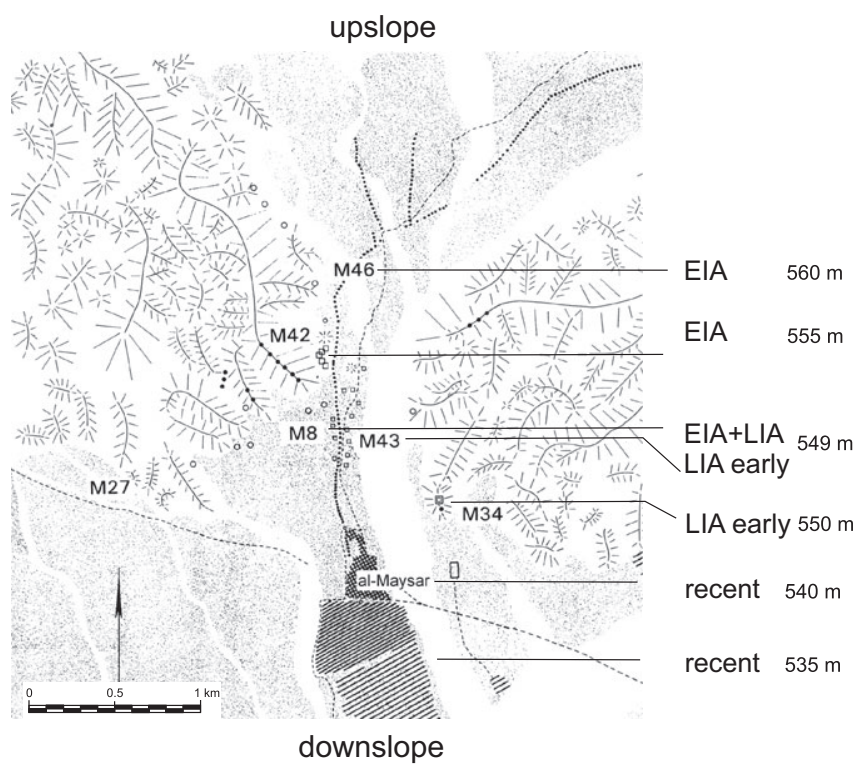

Fig. 10.

The 'falaj mechanics' (horizontal stratigraphy) of falaj M46 show the results of a lowering of the falaj and the exiting of the water at a lower elevation to the south. In other words, it is easier to move the settlement than to dig a well in order to raise the water to the surface.

figs. 22-26) visible in the excavated sections. South of one of these, after M4307, there is a lateral break of some $150 \mathrm{~m}$ after which the hills with Samad LIA surface sherds arise again. This gap suggests at least two LIA falaj lowering phases in harmony with Weisgerber's 'falaj mechanics'. Similarly, M42 and M4302 appear to be another still earlier falaj phase, prior to these. Two more follow in the sub-recent and recent periods-five phases in all. The lag in years between the late EIA M42 and early LIA M4304 is unknown.

\section{Selected relevant sites}

\section{Al-Moyassar M42, settlement}

In 1981 A. Tillmann excavated both the EIA settlement M42 and the nearby small LIA house mound, M4304. In 1996 Falb, Schreiber and Yule expanded the M42 trench (Table 9; Yule \& Weisgerber 1999: 104-108, esp. figs. 7, 8 ) in order to track more closely the transition from the EIA to the LIA along falaj M46. M42 is important for three main reasons: it is the oldest settlement which M46 spawned, evinced much stratified EIA pottery and yielded a thermoluminescence date of $288 \pm 170 \mathrm{BCE}$ from a large storage vessel base in situ (Weisgerber 1981: 223, Abb. 58; Yule \& Weisgerber 1999: 101, 106, fig. 8; Wagner \& Yule, in press: fig. 1). Mouton's aspersions regarding the integrity of the stratigraphy of this dating sample ('...but this single sherd could also have come from one of the graves...' Mouton \& Schiettecatte 2014: 86 and n. 143) ignores the simple published descriptions, photographs and drawings. Similarly, his downgrading of the excavated M42 pottery as 'surface finds' is incorrect (Mouton \& Schiettecatte 2014: 86) (Fig. 13).

\section{Al-Moyassar M43, chain settlement and M4302, house foundation ruin}

M43 consists of a linear scatter of manmade hills each about $25 \mathrm{~m}$ apart from the next, which flank the falaj bilaterally (Table 9; Tillmann 1981: 234). Most of these range from 6-10 $\mathrm{m}$ in diameter and stand up to $1.5 \mathrm{~m}$ in height. They represent the remains of mud-brick houses. After 1981 unpublished pottery drawings from M43 were inked, which bear provenance numbers up to hill no. '4-32', but Weisgerber counted forty-four hills for this settlement. Some yielded no surface pottery. Today's villa settlement, al-Moyassar, continues to grow towards the north and has eradicated most of the M43 hills (Yule \& Weisgerber 1999: 98).

The EIA dwelling, which once stood on top of the $22 \mathrm{x}$ $32 \times 1.8$ m mound, M4302 (Fig. 10), was not extant as excavated. Four profile views show alternating layers of disintegrated mud brick segregated by gravel lenses probably built up and later eroded from the structure over the centuries. Originally the house plan itself was far smaller $(5 \mathrm{x}$ $5 \mathrm{~m}$ ?) than today's tell, to judge from the tell shape and size. 
PAUL A. YULE
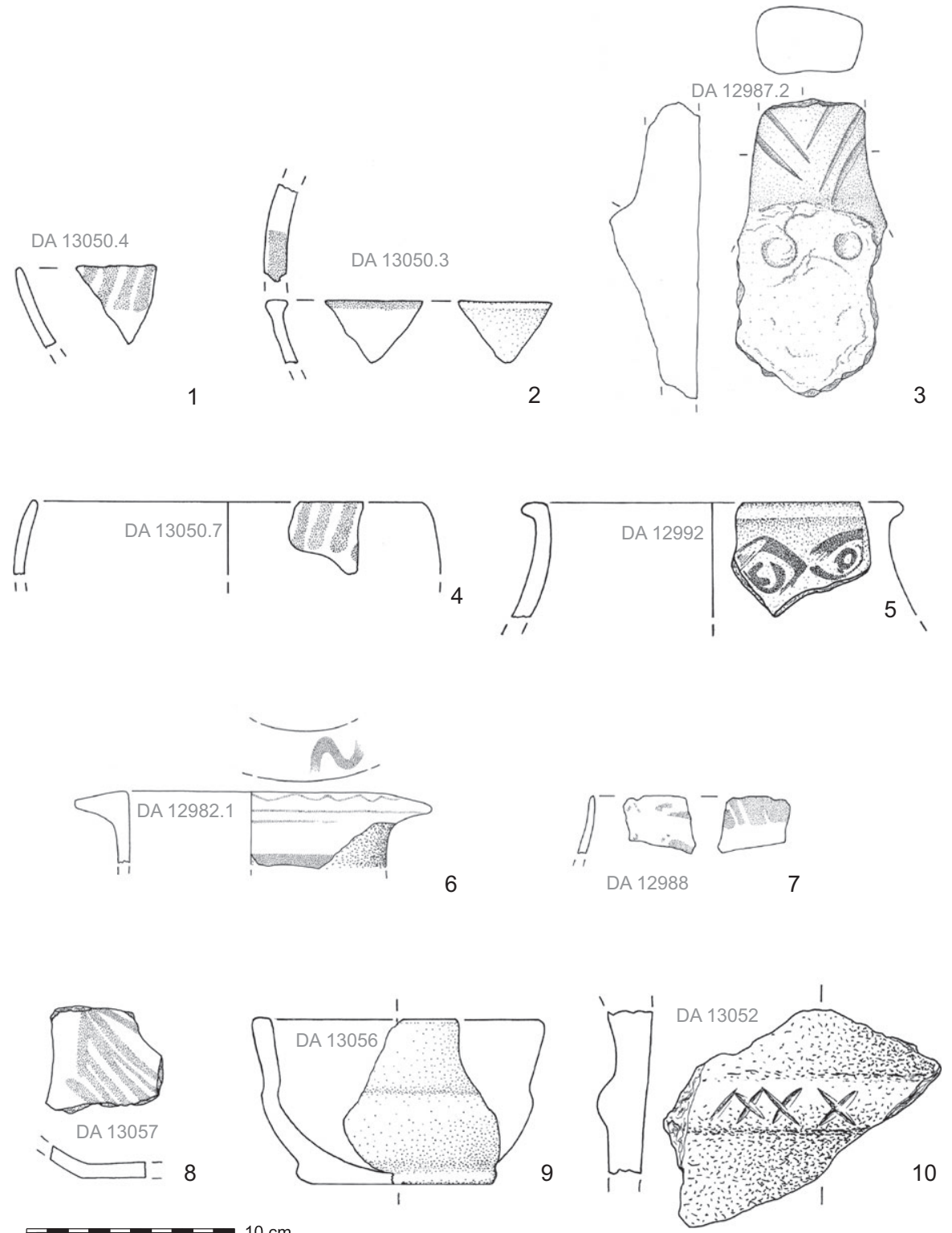

Fig. 11.

Stratified EIA pottery excavated in 1996 from settlement M42.

The available pottery excavated from sites M42 and M4302 (respectively Figs. 11 \& 13; Yule 1998) ${ }^{18}$ are of local EIA type indistinguishable from that of the exclusively EIA Lizq fort L1 which is comprehensively described by S. Kroll (2013: 191-193). His student, J. Schreiber, dates the pottery from L1 to EIA II (2007: 52 map 8) in the chronological nomenclature for the area (Schreiber 2010: 52 map 8). Schreiber considers

18 The title of the 1998 study is a little misleading, because it mentions 'M43' instead of 'M4302'.
M42 to be '...probably relatively late within the Early Iron Age...' (2007: 60 [translation]). Its pottery is more difficult to compare with that of the EIA Salūt fort, 91 $\mathrm{km}$ to the west as the crow flies (Phillips 2010: 71-76), the next closest EIA site with at least some published pottery. For example, neither the EIA al-Moyassar sites nor L1 yielded the EIA III diagnostic Burnished Maroon Slipped Ware known from there (Yule 2014: pl. 1/ $5)$. The thermoluminescence date and chorological position provide reasons to suggest a slightly later dating for M42 and M4302 than for L1. Seen retrogressively, 

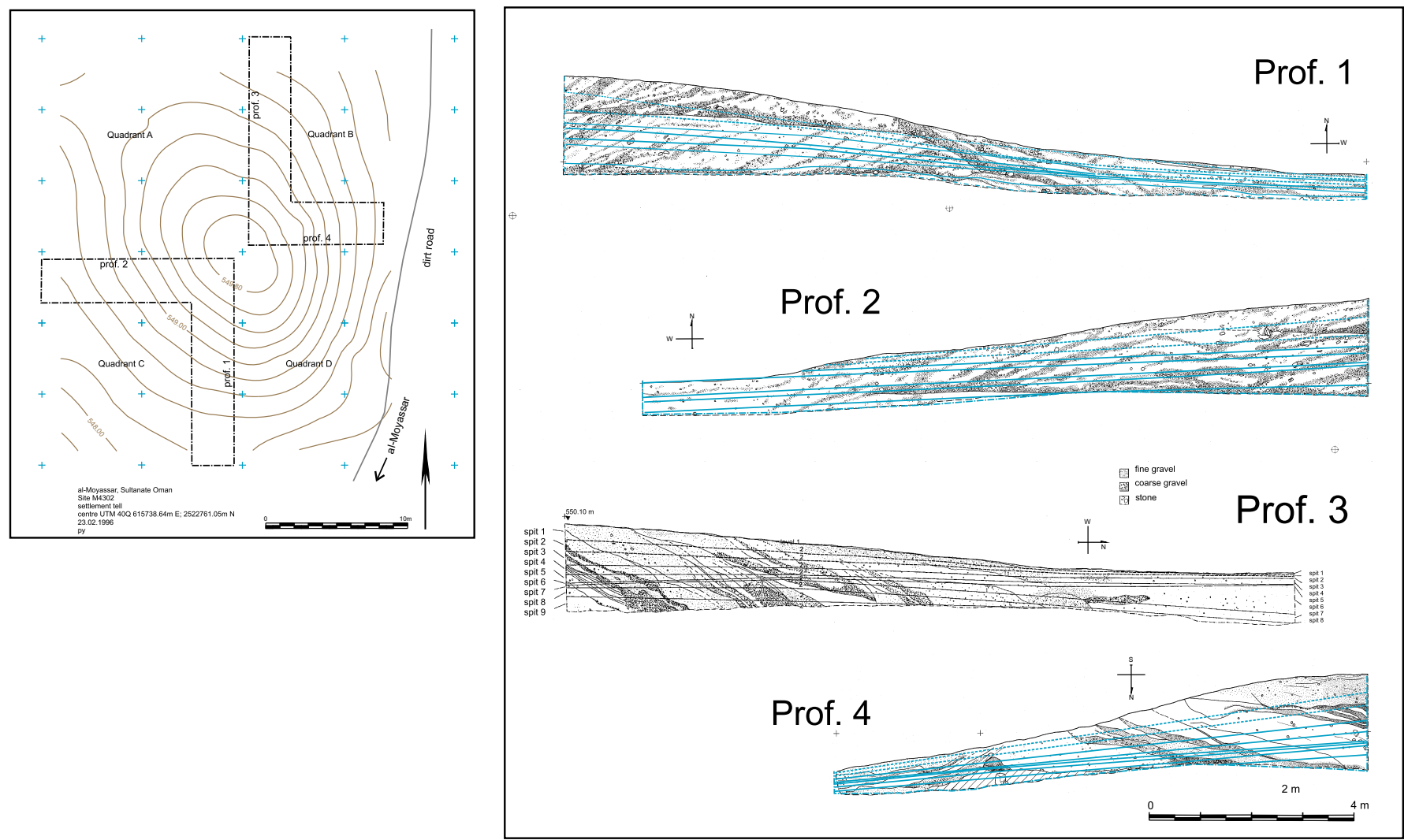

Fig. 12 .

The plan and four profiles of the EIA hill M4302 show the remains of a mud-brick house foundation.

the chorology suggests that M42 is close in date to the succeeding M43.

\section{Al-Moyassar M4304, house ruin}

M4304, one of the northernmost of the chain of house ruins mentioned above, lies $c .250 \mathrm{~m}$ south of a small mountain that served for Muslim period burials. Other spatial reference points are the late EIA settlements of M42 (368 m to the north-west) and M4302 (154 m to the north). Tillmann made two end-to-end trenches in this hill, both $1.4 \mathrm{x} 4 \mathrm{~m}$ in area, which today are still visible. At $c .1 .45 \mathrm{~m}$ depth he reached a thick clay house floor in his trench 1 . Trench 2 was shallow and was not pursued. In his report, he mentioned two levels/phases, one above the other. Although he wrote that the lowermost house contained pottery like that of the nearby EIA M42 settlement (Tillmann 1981: 238), none of the sherds reproduced in his report for M4304 or which are unpublished are of EIA date.

The unpublished find drawings refer to context ' 43 4/1', meaning al-Moyassar site 43, house 4, trench 1 . Other inconsistent site designations ('43 4-1', 'M43/4' and 'M4304'), which Mouton points out (Mouton \& Schiette- catte 2014: 86), may well lie at the root of his doubt regarding the integrity of Weisgerber and Yule's chronology. Similarly, A. Benoist cites this same erroneous site number as it appears in the original report (2000: 286). Moreover, Schreiber redated 'M43' to the EIA by virtue of the pottery excavated from mound M4302 without mentioning the published and unpublished LIA pottery, for example from M4304 (2007: 277 n. 1086). Evidently he considered all of M43 to be synonymous with mound M4302. Another confusing issue is P. Lombard's description of the composite site M43, 'Aucune information sur ce site d'habitat...' (1985: 144 fiche 55). Given the spurious sources regarding M43, Mouton's redating of M43 to the EIA is understandable, although this site yielded ample diagnostic stratified LIA sherds that fill four published plates which he describes as, "not supported by the publication of the material' (Mouton \& Schiettecatte 2014: 86). Despite the error in the original 1981 report, the bottom line for the description of site M4304 is a single-period site: early Samad LIA.

Considerable amounts of stratified, drawn, diagnostic pottery of Samad LIA type are manifest (Table 8; 
PAUL A. YULE
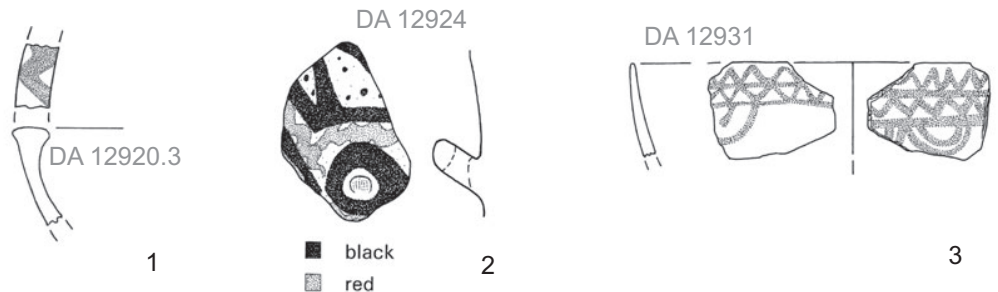

3
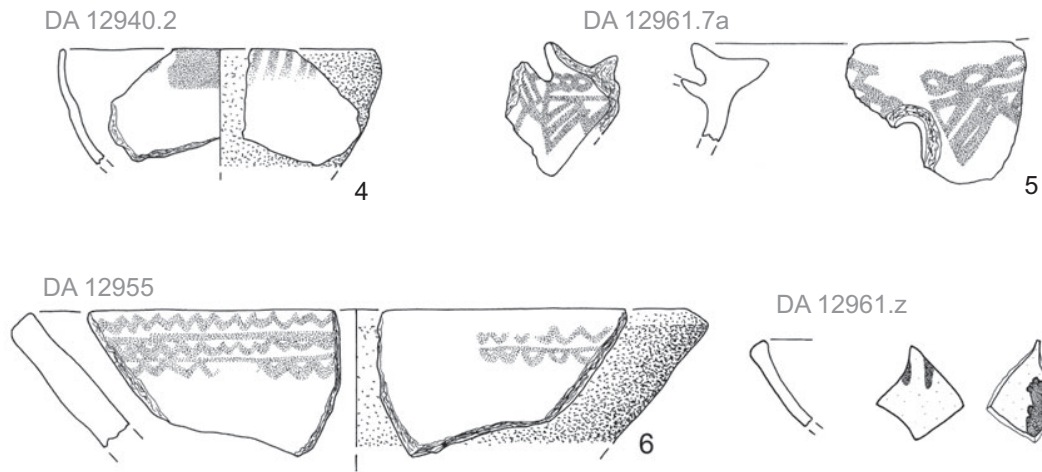

DA $12961 . z$
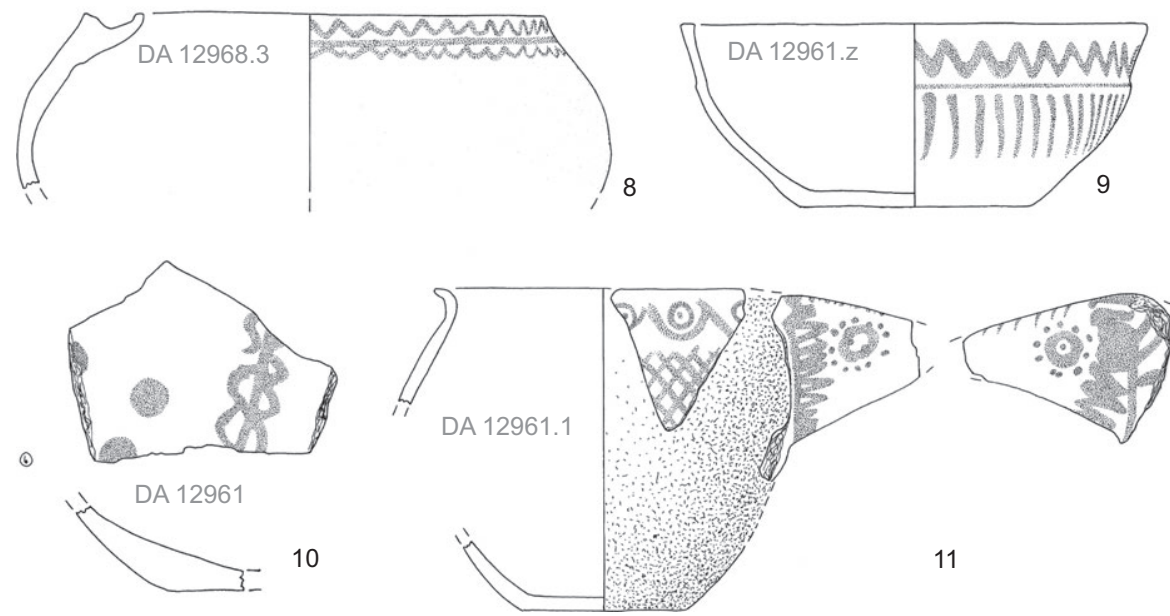

11

Fig. 13.

Pottery excavated from the EIA hill M4302 is exclusively of EIA date.

Fig. 15/1,4,7-10) (Tillmann 1981: 234-237 Abb. 78, 79/11-19, [sic 10-16]; see http://heidicon.ub.uni-heidelberg.de/pool/oman, 'M43' and 'M4304'). This pottery matches that of the nearby Samad LIA fort M34 and also early LIA graves (e.g. S2137, S2138, S3004). A tally of the M43 pottery drawings reveals three or four EIA sherds (Fig. 15/5,11; Yule 2001a, I: 390, II: Taf. $524 / 5,11)$, compared to 219 from the LIA. In 1981 Tillmann, then still a student of European prehistory,
Table 8. A dating summary of EIA and Samad LIA sites at al-Moyassar North.

\begin{tabular}{|lllll|}
\hline Site & Pottery & $\begin{array}{l}\text { Pottery } \\
\text { comparison }\end{array}$ & Type of site & TL dating \\
\hline M42 & EIA & Lizq L1 & settlement & $288 \pm 170$ BCE \\
M4302 & EIA & Lizq L1 & dwelling & - \\
M43 & mostly LIA & Lizq, M34 & 44 dwellings & - \\
M34 & LIA early & graves & fort & $130 \pm 150$ CE \\
M4304 & LIA early & graves & dwelling & - \\
M46 & none & none & falaj & - \\
\hline
\end{tabular}


VALORISING THE SAMAD LIA

Table 9. Sites mentioned and their locations, mostly Samad LIA settlements.

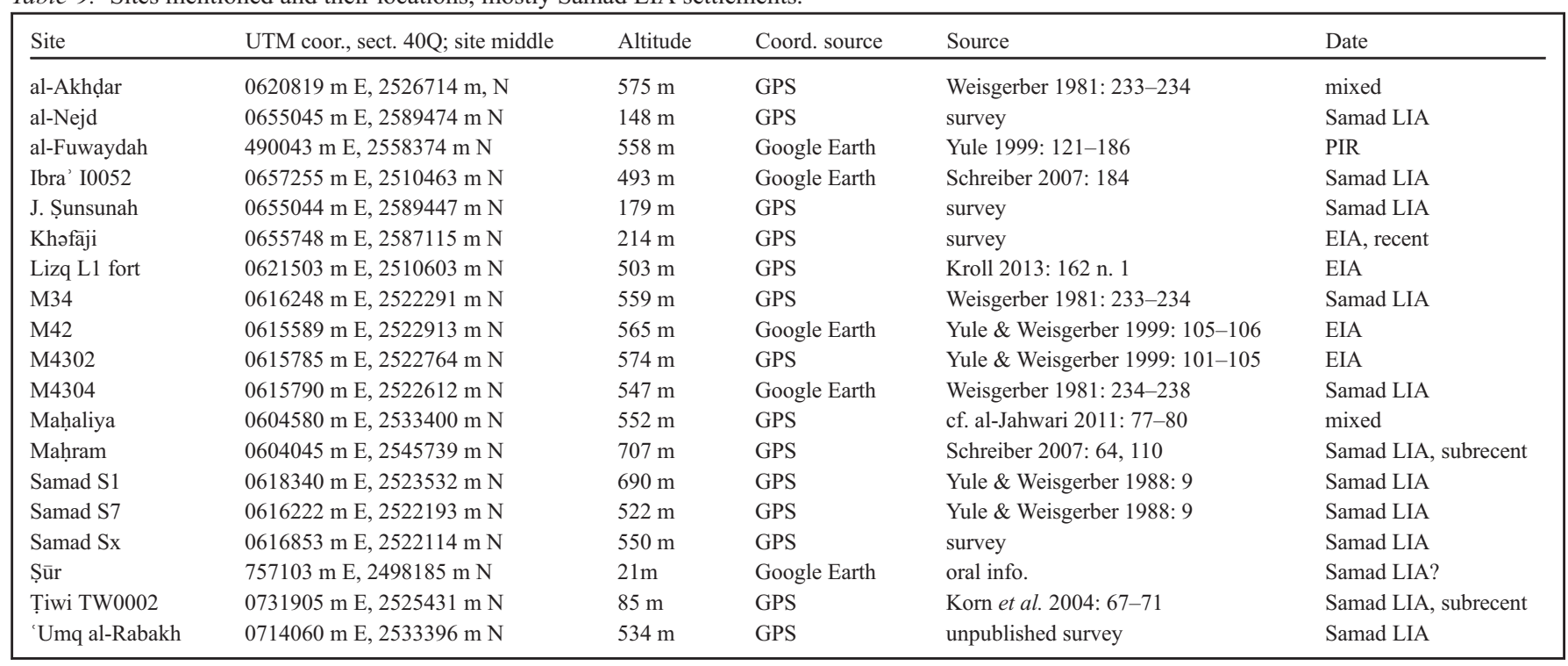

described the pottery fabric as 'very coarse', which is relative and slightly misleading. At that pioneering stage in 1981, at al-Moyassar most of the known pottery in the field was of the Umm an-Nar period. Levigated and finely tempered, this was probably the reference for his ware description. Five of the LIA sherds and two of the EIA sherds show painted decoration, but most consists of impressed wavy lines, short gouges and signs. Different bowls, bottles and storage vessels are identifiable in Tillmann's drawings. The unpublished notes on the inked drawings reveal that the sherds derive from different M43 house ruins (Fig. 15, Table 7).

Unfortunately, neither M42 nor M4304 yielded carbon for dating (Yule \& Weisgerber 1999: 105). To judge from the chorological north south settlement shift, the settlement continued during the LIA - the result of the rejuvenation and deepening of the M46 falaj. Lying closest to the EIA sites of M42 and M4302, chorologically speaking, M4303-M4304 must be among the earliest of the Samad LIA sites that arose along the falaj. Prior to excavation Weisgerber noted the LIA date of the survey pottery. One could query how many years had elapsed after the decline of the EIA settlement and the rise of the LIA ones in M43. The time span between the northernmost and southernmost LIA sites (see above) is short, as suggested by the homogeneous pottery. Aside from the settlement remains in al-Moyassar North, other sites exist in other parts of the country which are less well known (see below). Tillmann's observations regarding al-Moyassar North verify the chronology and chorology of Weisgerber as well as the author's (Yule 2014: 44-45, fig. 19).

\section{Al-Moyassar M34, hill fort}

Located $480 \mathrm{~m}$ east of the neighbouring LIA chain siteM43 - fort M34 is partially excavated, measures $33 \mathrm{x}$ $33 \mathrm{~m}$ in diameter and consists of casemates (Tillmann 1981: 233-235). Its stone wall is slightly over $1 \mathrm{~m}$ in thickness and probably stood not more than $2 \mathrm{~m}$ in height. Mouton attacks the LIA dating (Mouton \& Schiettecatte 2014: 86, missing on the map on p. 84 fig. 67; see Table 9; Yule 2014: 32, fig. 11). ${ }^{19}$ In chorological and pottery terms M34 has the same dating as the settlement laterally adjacent to falaj M46. He attempts to redate the architecture of M34 by means of the EIA forts Lizq L1, Huṣn Madhab and Bithnah 24 (Benoist et al. 2013: 41, fig. 10). In short, the only shared resemblance consists of their being located on a mountain, otherwise they are completely dissimilar in form, building technique and size. In fact, M34 is unique and bears no clear resemblance to any other EIA (cf. Yule 2014: 36, fig. 14) or LIA fort. Mouton then redates a copper alloy P10 arrowhead found there

19 'If qanat M46, at Maysar, was actually associated with the dwelling of the Samad culture...' Mouton \& Schiettecatte 2014: 95. This subjunctive formulation clearly expresses his doubt. 
PAUL A. YULE
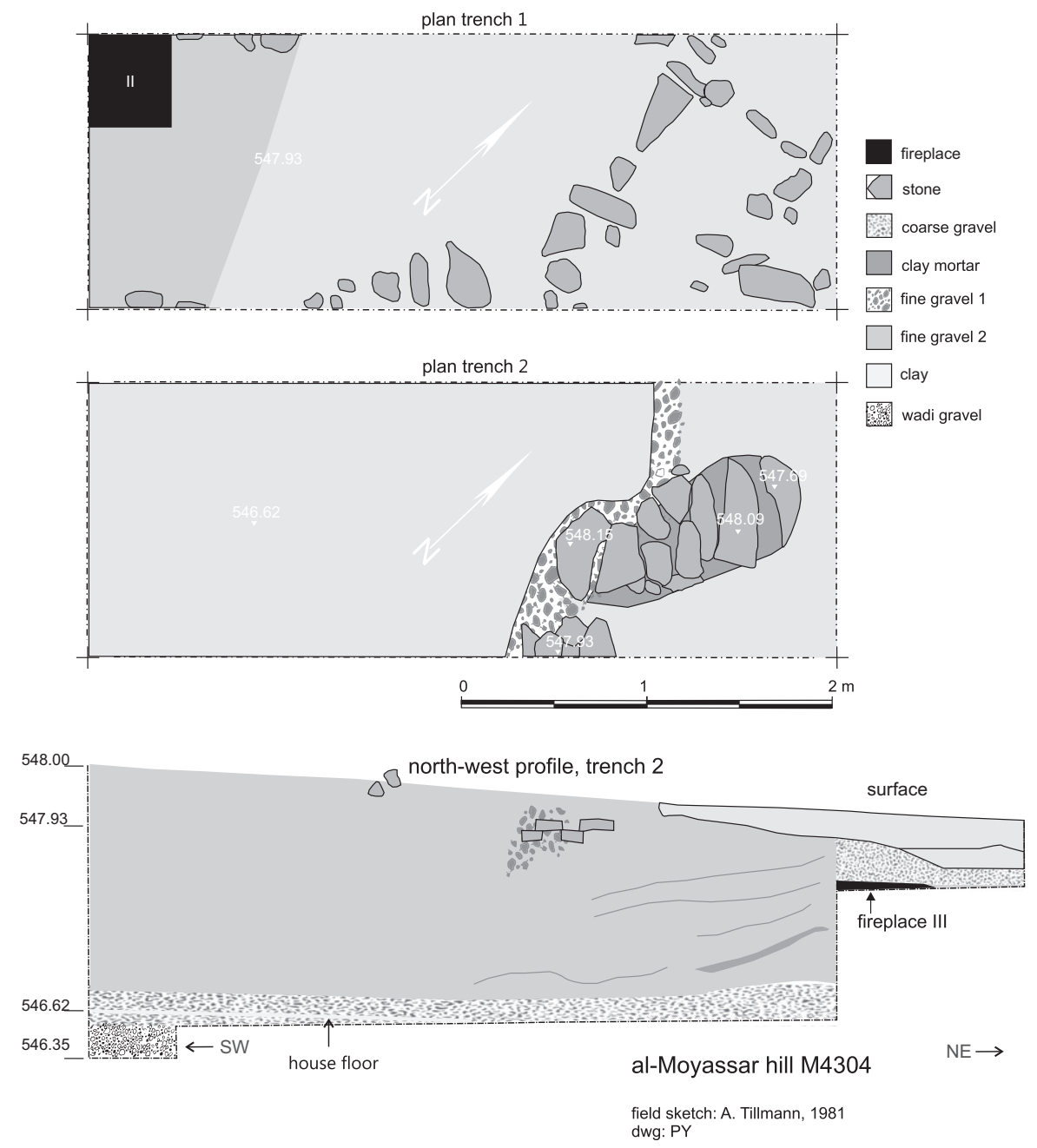

Fig. 14.

Plans and profile of the Samad LIA hill ruin M4304.

(see Fig. 5/P10; Yule 2001a, I: 103, 108, mostly from LIA, and also EIA III contexts) in support of his EIA redating of the fort. Previously, however, he had not defined this arrowhead as a type for his chronology (Mouton 2008: figs. $22 \& 23$ ).

The typologically earliest two pottery sherds from M34 (Yule 1999b: 141, figs. 18/6,7) can be cross-dated with the Sg30 stone vessel class, identical with Mouton's AC type (see Fig. 3/4). No other examples of the unpublished sherds are known to the present author. Fifty-six other published sherds from M34 are of Samad LIA date. A PIR.A comparative dating best fits their evidence and they need not necessarily be EIA heirlooms. The thermoluminescence datings for M42 and M34 were intended to substantiate the falaj chorological developmental scheme (Wagner \& Yule, in press). Mou- ton does not mention his dating references, M34's chorological site position, the thermoluminescence dating $(130 \pm 150 \mathrm{CE})$ or the six pages of published pottery drawings, but he concludes, 'the material found there does not indicate a later [LIA] date' (Mouton \& Schiettecatte 2014: 86).

\section{South of al-'Amirat/al-'Atqiyah/al-Nejd, fortified settlement}

On 6 April 2014 Nașir al-Wuhaybi brought a nicely preserved reddish 'copper' coin to the Ministry of Heritage and Culture in al-Khuwayr, a find that he had made at his home in al-Nejd (Table 9). Al-Wuhaybi is known in the ministry and commercial interests do not influence his provenance information, therefore doubts on the authenticity can be excluded (see below). 


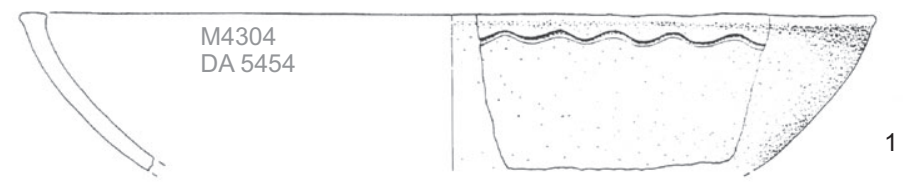

1
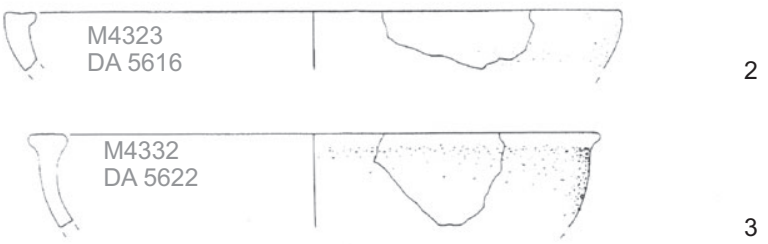

3
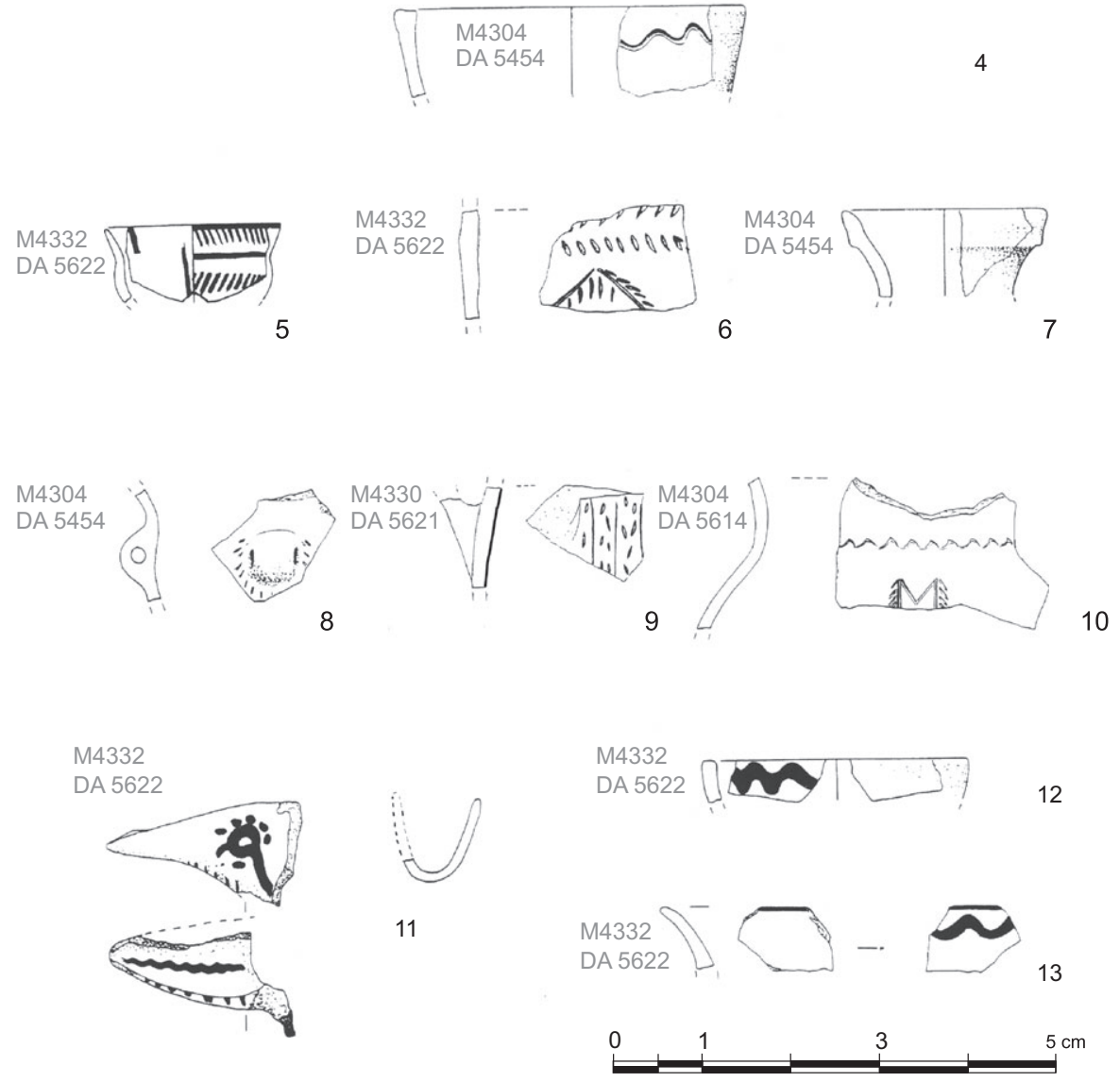

Fig. 15.

Of the 219 sherds from settlement M43, most are of Samad LIA date, but nos. 5 and 11 are of EIA date. Most of the unpublished M43 sherds were excavated from the M4304 dwelling.

On 13 April 2014 Khamis al-Asmi, Walīd al-Mandri, Nasiir al-Wuhaybi and the present writer visited the site, only $30 \mathrm{~km}$ from the ministry and readily accessible by car. The site is a small mountain situated next to a village (Figs. $16 \& 17$ ). Enclosures are scattered on the ridge of the mountain on its southern crest. The settlement measures $40 \times 75 \mathrm{~m}$ and is $20 \mathrm{~m}$ high; there are several mud-mortared, stone, one-room chambers, regular and irregular in form. Some are possibly small dwellings, others perhaps storage chambers. The largest are $5 \times 2.5 \mathrm{~m}$. In all there were perhaps twenty of these. They are difficult to spot from the wadi/garden side to the east.

Surface pottery sherds are typical Samad LIA standard ware (Fig. 18). The perfectly clear identification relies on 


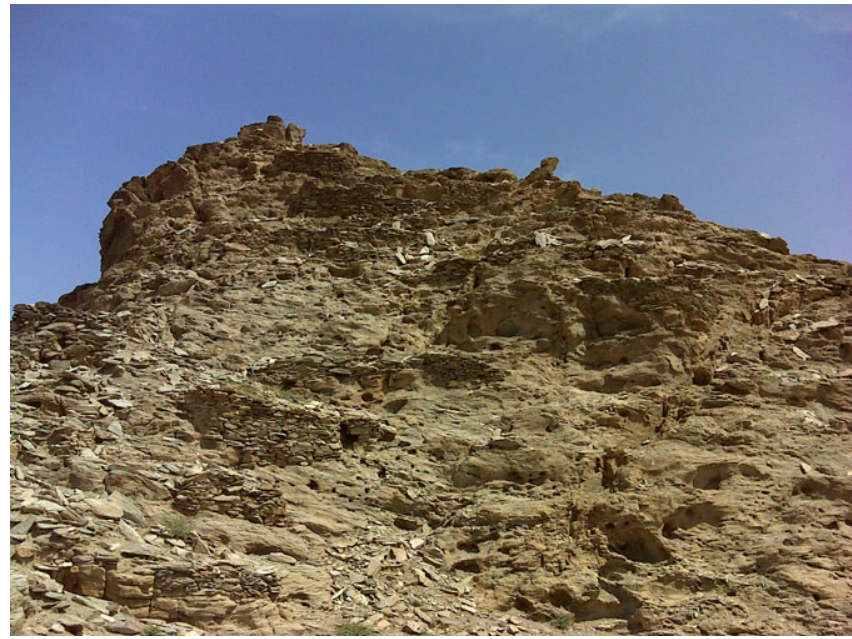

Fig. 16.

A Samad LIA fortified settlement near al-'Atqiyah/al-Nejd, looking towards the north-east.

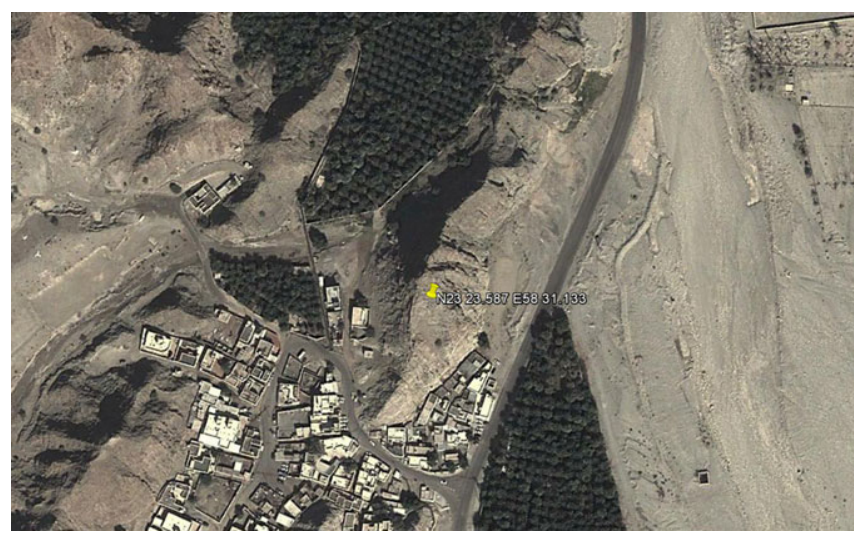

Fig. 17.

A satellite image of al-Nejd, a Samad LIA fortified settlement.

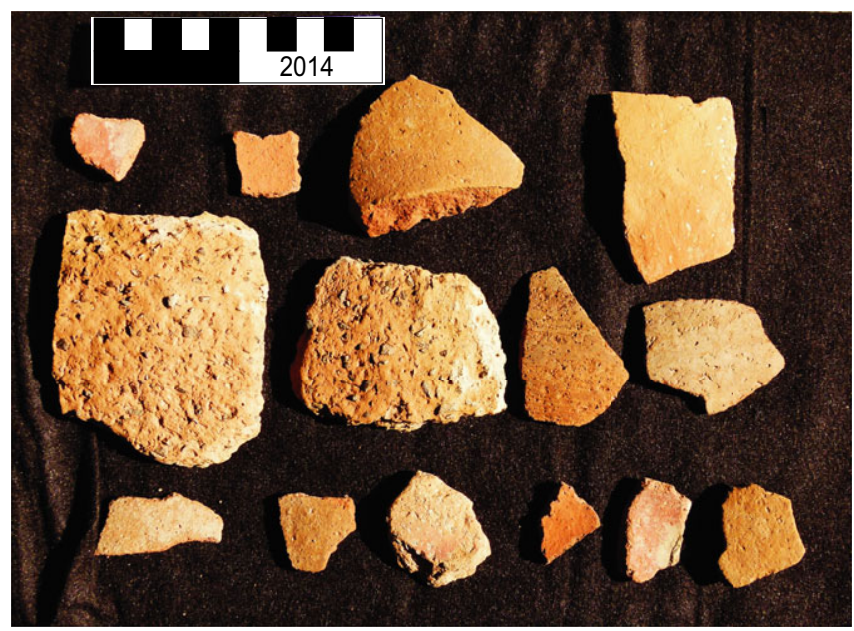

Fig. 18.

Samad LIA surface pottery collected at the site of al-Nejd.
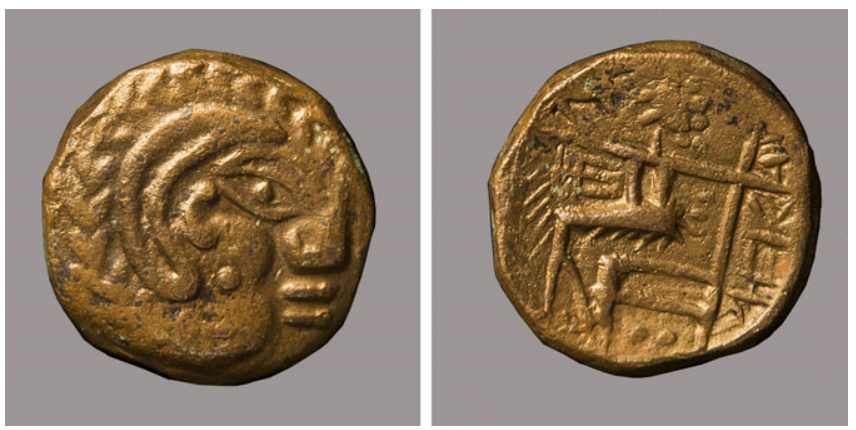

Fig. 19.

A copper alloy coin (DA 41871) found at al-'Atqiyah/al-Nejd is a clear import from northern Oman. The reverse view (right) indicates that the die axis is $10^{\circ}$ off the vertical axis of the obverse (left).

the fabric, but the vessel shapes are also standard. Al-Wuhaybi showed the visitors the find-spot of the coin in the centre of the settlement.

The coin is a tetradrachme of Alexander type, well known from Mlayḥa and ed-Dur (Yule 2014: 17, figs. 3 \& 4). It is struck, weighs $17 \mathrm{~g}$ and measures $23.29 \mathrm{x} 23.65 \mathrm{x}$ $5.81 \mathrm{~mm}$. The coin shows no oxidation because al-Wuhaybi has cleaned it (Fig. 19). The obverse shows a schematised Alexander head facing right. The 'Amun horns' are formed of a plain crescent and the 'lion mane hair' is a simple fishbone pattern. The reverse shows a seated deity. The 'Aramaic' legend is best recognisable when compared to legible examples, as Macdonald has published. It is a mirror-imaged, meaningless, debased version of the personal name Abi'el ('b(y)'l; Potts 1991: 86-87) which means 'my father is El' (W. Nebe, personal communication). The images fit best into D.T. Potts's XLVII iconographic class (1991: 86; Macdonald 2010: pl. 8/1 ANS.1992.64.21 [T]). The main difference is that our coin is made of 'copper' whereas those of class XLVII are invariably struck in billon. Potts assembled parallels similar in style, iconography and technique. In his 2010 study Macdonald writes, 'P94.380 in subgroup D.1.4.3.c (=no. $10 / \mathrm{h}$ on pl. 10) is almost certainly from the same reverse die as your coin. The only possible inconsistency is the posture of the animal on the figure's right arm, the traces of which on your coin suggest a different posture from that on P94.380, but this could be a trick of the light on the photo. It also looks as though the obverses are from the same die (see Potts Supplement [1994]: 70, no. 380)' (correspondence 23/11/2014). P. Van Alfen published a large selection of Abiel coin images. When asked about this coin, he replied, 'The differences in wear and striking notwithstanding, I am pretty certain that your coin is 

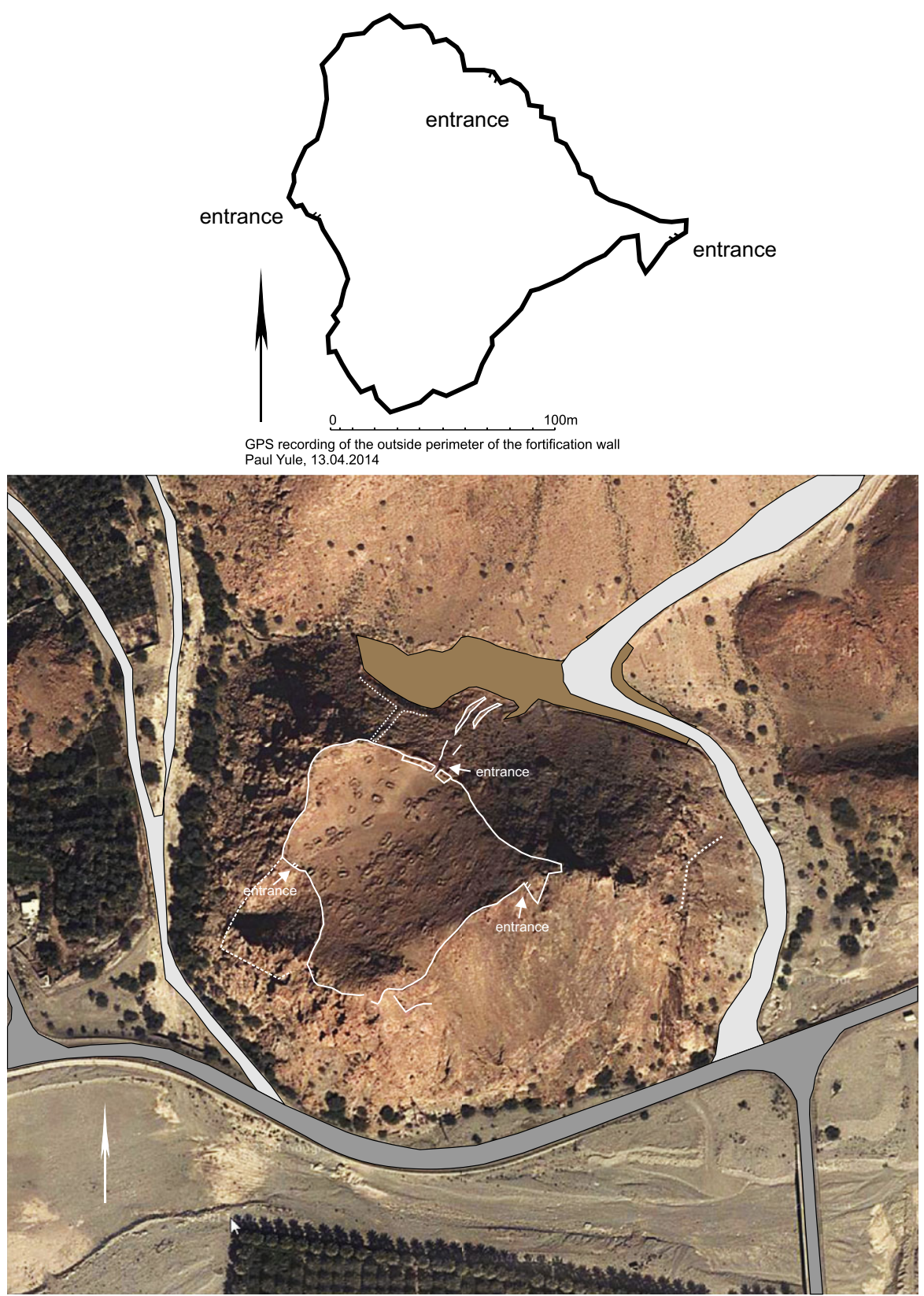

Fig. 20.

Top: Al-Atqiyah/J. Șunsunah, a Samad LIA fortified settlement, GPS sketch; bottom: GPS sketch of al-Atqiyah/J. Șunsunah combined with a Google Earth view.

die-linked to both obv to no. 237 in my study (2010: pl. 37, no. 237; Macdonald D 1.4.3.c). ${ }^{20}$ The dating of these coins is all but impossible for lack of any suitable hoard

20 The legend comes closest to Macdonald's description as a 'vertical one-name Abiels with the legend ' $b$ 'l on the right with barbarised forms of ', $b$ and $l$ '. material, for relative dating, or secure archaeological contexts, for absolute dating. The best guess is somewhere between the $2^{\text {nd }}$ to $1^{\text {st }}$ centuries BCE.' (P. van Alfen, correspondence 29/12/2014).

Aside from the finds from the PIR grave inventory Bar1 at Sama' 1 , this find is the first certain one from Mlayha or ed-Dur to occur in Central Oman. It is the first coin found 
stratified with Samad LIA pottery. A few examples came to light at distant Khawr Rurī in Oman's South Province (Sedov 2008: 302).

\section{South of al- 'Amirat/al- 'Atqiyah/J. Șunsunah, fortified settlement}

Some $1460 \mathrm{~m}$ north of area of al-Nejd, also near al-Atqiyah, lies a settlement on an escarpment with a defensive wall (Fig. 20; Table 9). The northernmost part of the site at its base shows some bulldozing damage. The dry-stone defences are preserved maximally $3 \mathrm{~m}$ in height and $1.5 \mathrm{~m}$ in thickness. This structure is large, measuring $154 \times 150 \mathrm{~m}$. At the south-west corner lies an enclosure separate from the rest of the settlement. It is irregular in shape, following the topography. Upwards of eighty ruined small stone huts are estimated inside the main enclosure. The mountain lies favourably next to the large Wādi Mayh, $50 \mathrm{~m}$ towards the east of the foot of the mountain, which flows towards the north-east. This provides a reliable source of water for local irrigation. The defensive wall follows the crest ridge and is irregular in form, which suggests different building phases. The settlement appears to be inhabitable and has well-preserved huts that measure up to $6 \times 2 \times 1.5 \mathrm{~m}$ (max. preserved).

The fortified village has three exits: the main one in the north has a stairway and flanking casemate walls which are badly damaged. An exit lies in the west and a nearly destroyed fortified one in the east. All three need not be contemporary with each other, as suggested by differing states of preservation. The obvious subsistence problem is a source of water for the inhabitants. Fireplaces are not obvious. The gardens lay originally outside to the west, to judge from the topography.

Surface pottery clearly of Samad LIA fabric and shape occurred inside the walls.

\section{South of al- 'Āmirat/al-Atqiyah/Kh'äaji, mountain peak fortification}

This year al-Wuhaybi led the present writer to a further stone enclosure $900 \mathrm{~m}$ south-south-east of al-Nejd at Khəfaji, the date of which is uncertain. The few small pottery sherds found on the surface appear to be of EIA ware (Table 9). This scalene triangular fortification is oriented north-east south-west and measures $80 \times 15 \mathrm{~m}$ in plan (see http://heidicon.ub.uni-heidelberg.de/pool/oman, keyword: Khafaji). The dry-stone masonry (about 50\%) is of the sandwich type, which is of pre-Islamic date. The enclosure wall is preserved up to $1.5 \mathrm{~m}$ in height. The rest of the masonry could be of any date.

\section{Tìwī/al-Jurayf TW0002, fortified settlement}

Sited in 2002 this settlement is nearly as large as that on the J. Sunsunah, and was inhabited in the Samad LIA and Islamic periods (Table 9; Korn et al. 2004: plan p. 70, fig. 4). Samad LIA and ninth- to sixteen-century remains were found (for dating, see Schreiber \& Häser 2004: 326). Houses were built on the slopes on both the north and the south sides of a mountain saddle, today

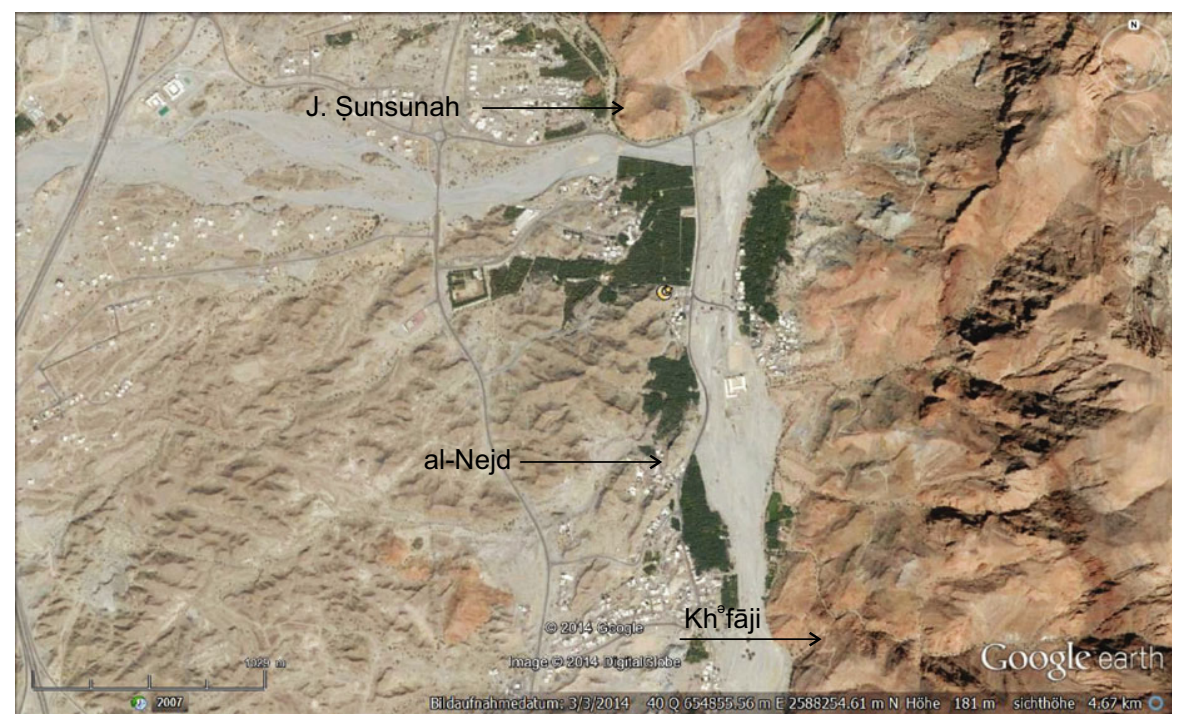

Fig. 21.

The locations of the Samad LIA sites al-Atqiyah/J. Sunsunah, al-Negd and $\mathrm{Kh}^{\curvearrowright}$ fãji. 


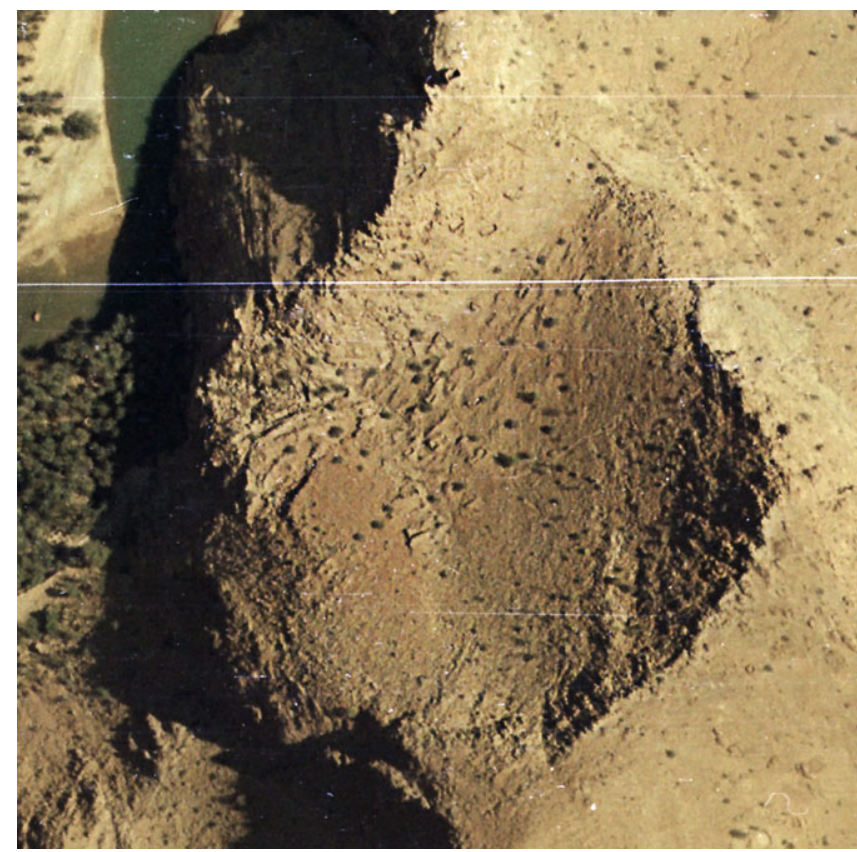

Fig. 22.

Tịi site TW0002, a Samad LIA fortified settlement site, as it was in 1981, (north at top).

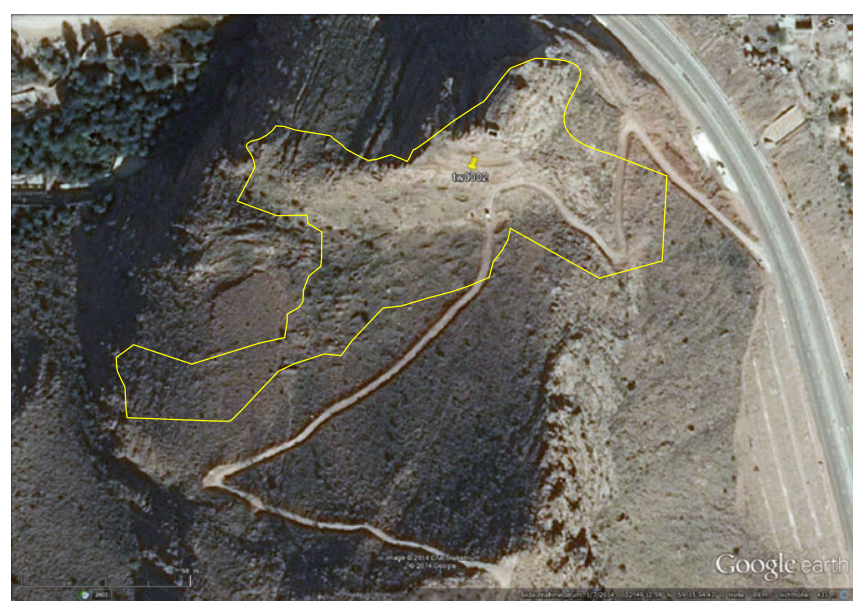

Fig. 23.

The site in 2014; the light coloured line shows the site perimeter.

hardly visible from the wadi or from the shore. The saddle is favourable for rain catchment. The $195 \times 220 \mathrm{~m}$ site, the largest of its kind for this period, is extremely difficult to draw, although the Tübingen team had draftswomen and a tachymeter. The site view which Korn and his colleagues published in 2004 is a view to the northnorth-west of the oldest and most densely built part of this permanent settlement, its northern half (Fig. 24).

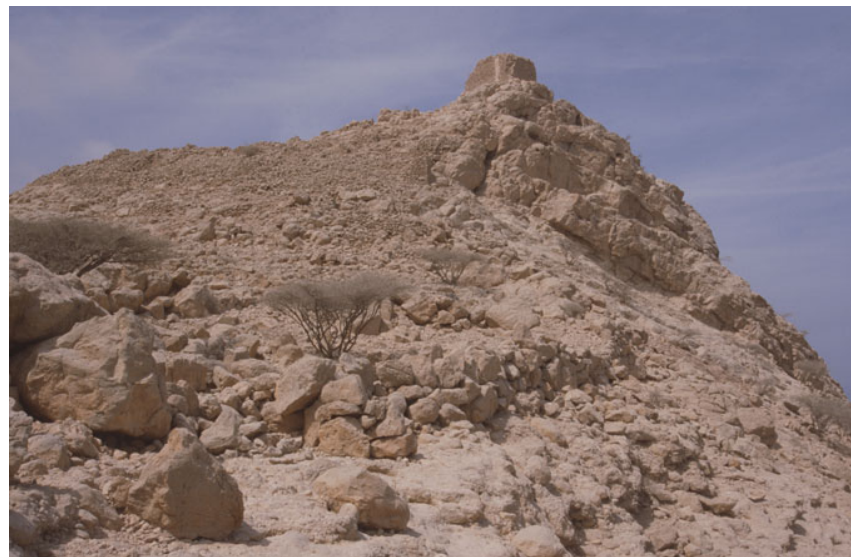

Fig. 24.

The northern part of Ṭî̄ì site TW0002 in 2002.

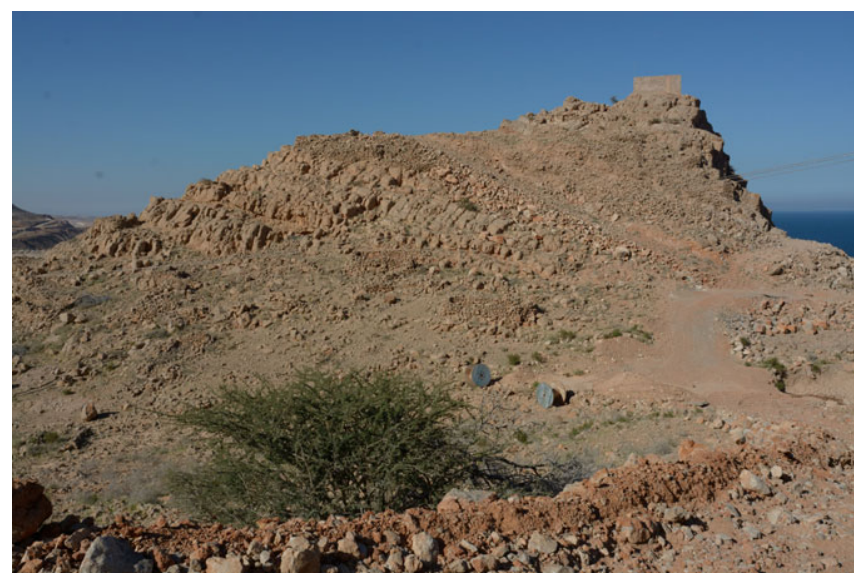

Fig. 25.

The condition of Tîwī site TW0002 in 2014, looking towards the north.

There is no evidence of a garden or water inside the escarpment settlement.

An aerial and satellite images (cf. Figs. 22 \& 23) show the site destruction between 1985 and 2014. Since 2004 mast erection, quarrying and a track bulldozed through the ruins (see Figs. 23 \& 25) have destroyed critical parts of the northern slope of this context. The renewal of a small Islamic period enclosure to the very north necessitated a service road, resulting in further damage.

The published plan of TW0002 north distinguishes house plans and terrace walls (J. Häser, personal communication). Much of the LIA building material seems to have been reused in subsequent occupation. It appears that Islamic period masonry dominates in the regular floor plans in the north, which in light of the destruction of the site is difficult to verify. This masonry manifests smaller 
stones that are more regular in size and is heavily mudmortared. The sketch plan is already historic as a result of destruction caused by road building, especially in the northernmost highest part of the site, where Islamic buildings are centred. It does not interpret but just documents. The concentric wall structure of the settlement pivots on the highest point of the site. Not visible in the centre of the sketch plan are concentric defensive walls facing south and east. The strongest walls lie at mid-slope height. The context and sketch terminate to the north-west with the cliff edge. Numerous terraces are what remain of houses. The house walls show sandwich wall construction. Some house plans measure up to $8 \mathrm{~m}$ in length.

Following intensive survey of 2002, the site contains little pottery but many mollusc fragments. Stones circular in section and concave on both sides suggest pounding or net stones. Perhaps the LIA fishermen brought their nets daily back up to the settlement. The site shows many hand-sized grinding stones but no saddle querns, which one might expect, although a few have yet come to light in clear Samad LIA contexts. It is possible these were removed after the site was abandoned. Both pottery sherds and architecture confirm a Samad LIA dating for TW0002 and a later reoccupation. The pottery is identical to that from Samad al-Shan in its fabric, hand-made technique, shapes and general appearance. Some of the wall masonry are reminiscent of Samad LIA tombs. The Islamic period structures are often built of LIA building stone. A trench would help to distinguish the two building techniques.

The loosely scattered cemetery contained an estimated 950 Samad LIA graves located on the natural terrace north of the mouth of Wādī Țiwi beneath and around the motorway from the south-west to the east of TW0002 across the wadi (see Fig. 2/2; Korn et al. 2004: 70). They contained

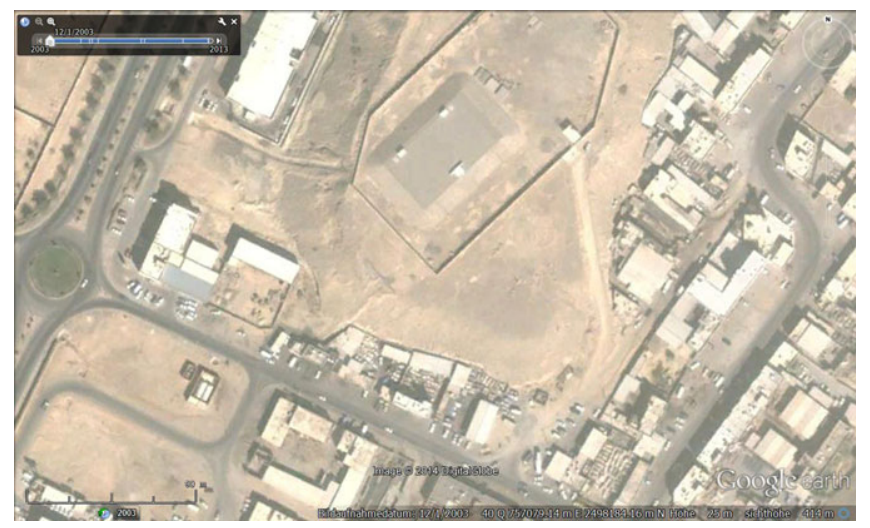

Fig. 26.

Șūr, a LIA 'fort', 2003. diagnostic finds. The topography largely conditions the grave orientation of the long axes. Sites peripheral to TW0002 are actively being bulldozed at present, especially to the west. More than $75 \%$ of the pre-Islamic graves were destroyed, mostly by the building of the coastal road and hardly any can now be identified.

\section{Șūr, 'hill fort'}

The site lies in the highest part of this flat area. Weisgerber noted the presence of an elevated Samad LIA fort, which he pointed out to the present writer in 1986 (Fig. 26; Table 9). It lies $200 \mathrm{~m}$ north-east of the biggest roundabout and a little more than $200 \mathrm{~m}$ west of the lagoon. Presently the site stands some $10 \mathrm{~m}$ above the surrounding area and over a decade ago was planed off to accommodate a water bunker. Originally the plateau on the mound may have measured $100 \times 100 \mathrm{~m}$. The size of the fort itself is unknown, built on a bow-shaped hill some $1.5 \mathrm{~km}$ in length. The south-east hill corner is still visible in a 2003 Google Earth image. An unpublished high-resolution aerial photograph of 1975 (1975HUSL00055500000748) does not reveal a fort on the natural mound and we cannot confirm its intended function or even if it existed. Presumably the description rested on the occurrence of pottery sherds found on the surface. Satellite images taken annually show how the surrounding businesses have encroached and snipped away at the edges of the hill.

\section{Samad S1, S7 and Sx, fortified settlements}

Weisgerber briefly identified settlements S1 and S7 in 1987 (Table 9; Yule \& Weisgerber 1988: 9; for map, see Yule 2014: 32, fig. 11), which were first verified in 2014. Settlement S1 (Fig. 27) is situated $400 \mathrm{~m}$ west of al-Khu-

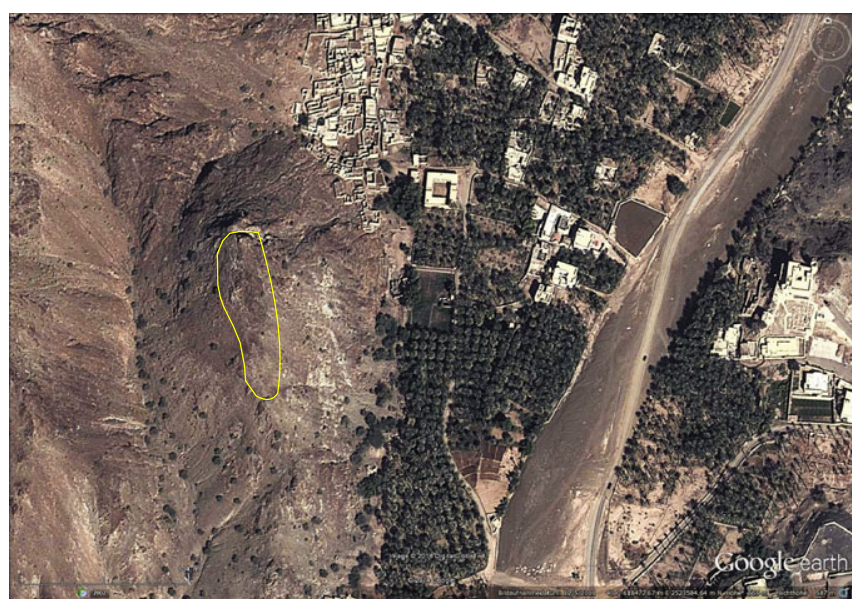

Fig. 27.

The Samad LIA fortified settlement S1. 
bayb castle. It is better preserved and larger than S7, measures $160 \times 10 \mathrm{~m}$ in surface area and is spread over a mountain ridge. It consists of over a dozen house ruins.

Today, settlement S7 is little more than a mountain over which innumerable Samad LIA sherds are strewn. Beside it lie what appears to be an early Islamic cemetery and settlement. Fragmentary walls are rare and we have little basis for an estimate of the LIA building surface area and shape.

Today site Sx, not identified by Weisgerber, is hardly recognisable as a building, let alone a stronghold or fortified settlement, as a result of erosion and vandalism. It is some $15 \times 15 \mathrm{~m}$ in surface. The broken ophiolite fragments lying on the surface are anthropogenic and represent what remains of the architecture.

At S1, Samad LIA surface pottery is abundant and a few EIA sherds occur. S7 also yielded numerous Samad LIA sherds. These are fewer on the slopes of site Sx.

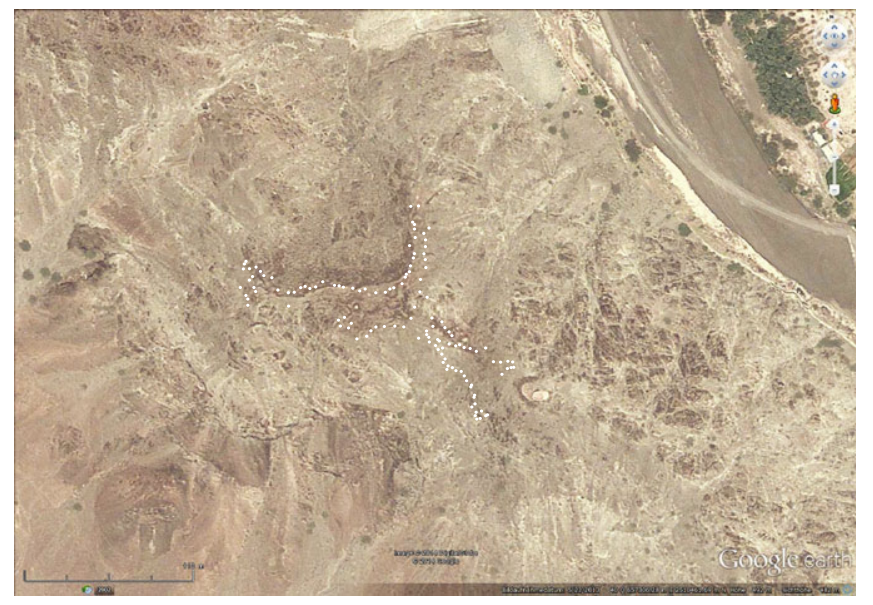

Fig. 28 .

Alāyat Ibra'/al-Qanātir, site I0052 as a GPS sketch.

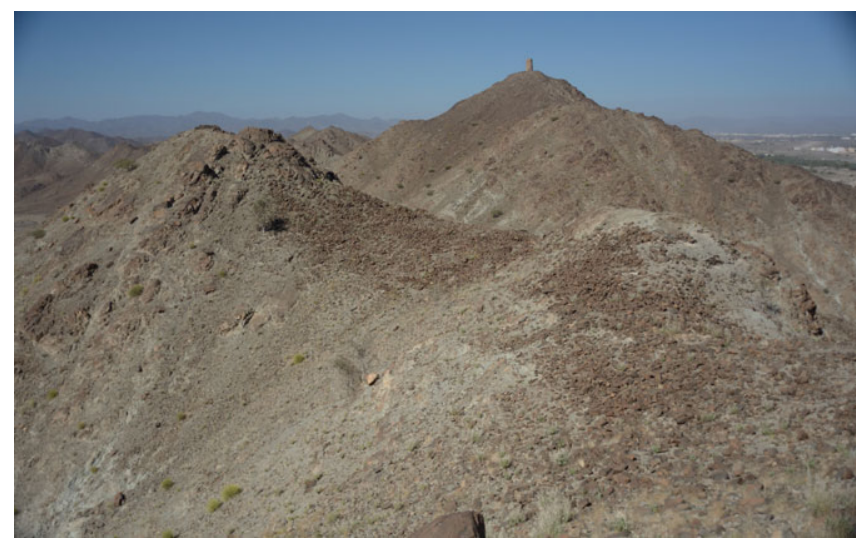

Fig. 29.

Site I0052 looking towards the north-west.
Wadi 'Andām/Mahaliya, probable fortified settlement Across the wadi from the cemetery c. $200 \mathrm{~m}$ to the east is a ruined enclosure dated by Samad LIA pottery (Table 9). It measures $70 \times 70 \mathrm{~m}$, is irregular in form and is visible in Google Earth (HeidICON 'Oman', keyword Mahaliya). It resembles a structure first sited by al-Jahwari (2011: 78, fig. 4 'CS 2.51.1'), but his 'stone circular alignment' differs from ours in shape and size. The mounded ruins that form its edge suggest casemate walls, rather than towers with curtain walls. The pre-Islamic cemetery is the largest that the present writer has ever seen in Oman. This results from a lack of encroachment here. There is no fort on the ridge near the present-day gardens, as one might expect, and the one just mentioned is almost $1 \mathrm{~km}$ to the southeast from the palm grove. While one assumes that the LIA palm grove was in the same place as today's, this need not necessarily be the case.

\section{Alāyat Ibrā'/al-Qanātị I0052, fortified settlement}

First reported by Schreiber (2005: 260-262; 2007: 184), this site is the second largest Samad LIA settlement known (at least $150 \times 110 \mathrm{~m}$ ). The outer walls of the main fortification are preserved as high as $3 \mathrm{~m}$ and lie in the northern part of the complex. The present writer also marked the main features with the GPS. The two sketches differ from each other in part because that published by Schreiber is

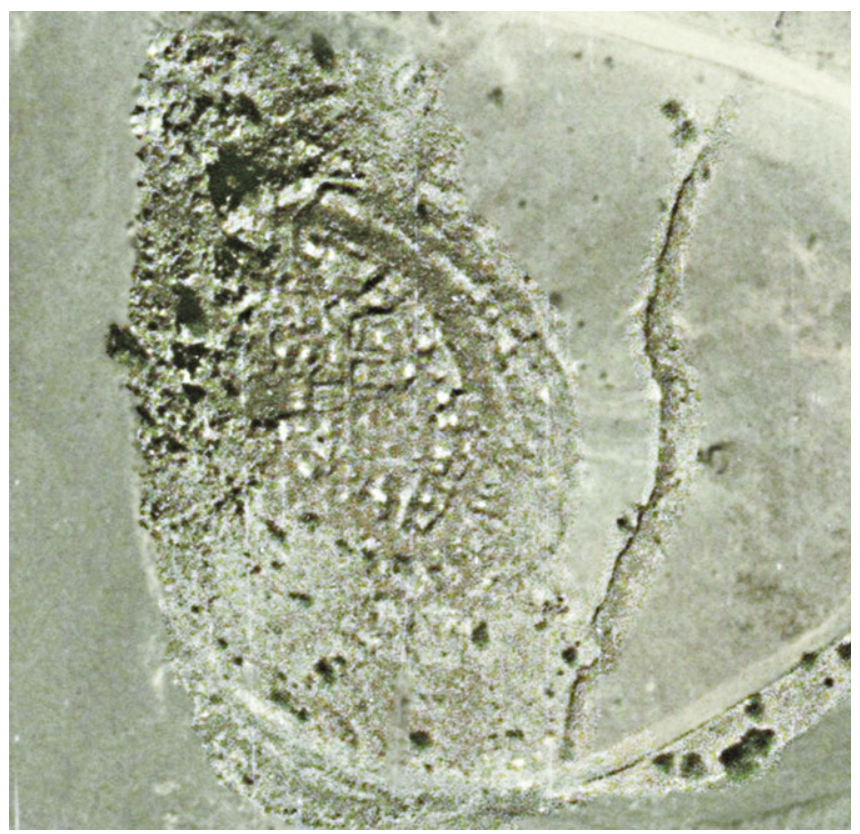

Fig. 30.

An aerial photograph (1985) of Maḥram/Qariyat al-Saih, a fortified Samad LIA settlement (north at top). 
not oriented and is oblique (cf. 2005: 260, fig. 7) (Fig. 28). The defensive perimeters of the two sketches also differ slightly (Table 9, Figs. 28 \& 29). Fortified houses flank the mountain ridge south-east of the main bulwark. Schreiber had more time to prepare his plan than the present writer and includes probable house plans, a few of which have survived. The dating arises from numerous Samad LIA sherds strewn among the disparate ruins. Later ones are rare and secondary and therefore not a result of continuous settlement. The new plan shows two concave lines that represent settlement fortifications. Between these lie dwellings. Originally the defences were necessarily closed. The preservation is better than at TW0002 because there has been no recent road building.

\section{Wadi Mahram/Qariyat al-Saih, fortified settlement}

In 2015 there was sufficient time to sketch the Samad LIA fortified settlement in Wādī Mahram. This settlement was noted by Gerd Weisgerber (Schreiber 2007: 63 maps 11, $64,110,171,175,277)$ who gave no specifics about it, for example, its exact location, size or plan. Even the dating could be questioned since no information was put forward. Three antiquities signs now stand to the east and north-east of the site near the road.

The state of preservation and our recording methods condition the appearance of the resulting sketch. More time with more sophisticated equipment (high-resolution aerial imagery, tachymetry, etc.) will improve the drawing. The main structure is some $50 \times 90 \mathrm{~m}$ in surface area. It lies as high as $70 \mathrm{~m}$ above the surrounding wadi. A garden lies $100 \mathrm{~m}$ to the south-west. Located deep in the wadi, it probably also existed in antiquity. The site is built adjacent to a low area. The west and south are protected by the wadi and its steep slope (see Fig. 30). Upslope, the houses have walls up to $80 \mathrm{~cm}$ in thickness. At key points there are irregularly shaped towers which have a thicker wall diameter. The gate construction is not preserved and leads the visitor into the village via passageways. In the south-east the irregular wall 2 is preserved up to $1 \mathrm{~m}$ in height. Further uphill, the heavier wall 3 encloses the core. In its midst lies a ruined Umm an-Nar tomb some $7 \mathrm{~m}$ in diameter.

Samad LIA pottery sherds and Islamic period sgraffiato, celadon and Bahla $\bar{a}^{-}$sherds occur on the site, ${ }^{21}$ which was reused and rebuilt. The Islamic period sherds are more numerous in the outer reaches of the settlement.

21 Photographs available at http://heidicon.ub.uni-heidelberg.de/ pool/oman, keyword: Mahram.
A large wall (no. 1) to the south-east thwarts the wadi south of the site and transects the site. This seems to be of recent date. It was broken through by the building of the road. Recent tsangirs (shooter's stone emplacements) are visible in and around the site. Islamic cemeteries occur to the north-east and south-east of the site. To the south-east an Umm an-Nar tomb has been divested of its stone.

Figure 30 shows a sketch made in the field complemented by means of a low-resolution Google Earth image. Amid the rubble, rooms and walls are difficult to reconstruct and entrances are difficult to identify. The sketch shows fortification walls maximally $1 \mathrm{~m}$ in thickness and passageways inside the fortification. Visible in the context are many changes made during the course of construction.

The building material was mainly unmortared stone. Abundant disintegrated mud brick and perhaps saruj lie amid the stones.

This fortified village differs from others of its time partly because of its relatively good preservation, as opposed, for example, to the LIA Tiwi tw0002. Its plan is more easily recognisable than that of Ibrä' I0052, in contrast to the loose scatter of LIA houses at al-Dar/'Umq al-Rabakh. Different factors condition the settlement plan which include, in particular, the topography and accessibility of the settlement. The use of casemate walls distinguishes LIA from EIA fortifications. To judge from the loose masonry, the qalat-like appearance of the buildings at the peak probably derives from the latest occupation.

\section{Summary and conclusions}

In 2014 the present author set about updating knowledge of the Samad LIA settlements, which are a rapidly diminishing cultural resource. Despite previous surveys, surface pottery was still visible at the different sites. Minor mistakes in the original 1981 report in referring to the pottery from the settlement M43 elicited a chain reaction in subsequent publications.

In Central Oman, EIA and LIA contexts never really occur stratified one above the other, a problem for the chronology but not an insuperable one. Despite considerable agreement, the point where Yule (2001a) and Schreiber (2007) least agree is on the suddenness of the transition to the Samad LIA in terms of the pottery typology. Schreiber (followed by Mouton) places the accent on survey data, Yule on published funerary excavation finds. The Samad LIA is known from over 200 published graves, many unpublished ones and hundreds known from surface observation. Early estimates of 3000 to 4000 LIA graves 


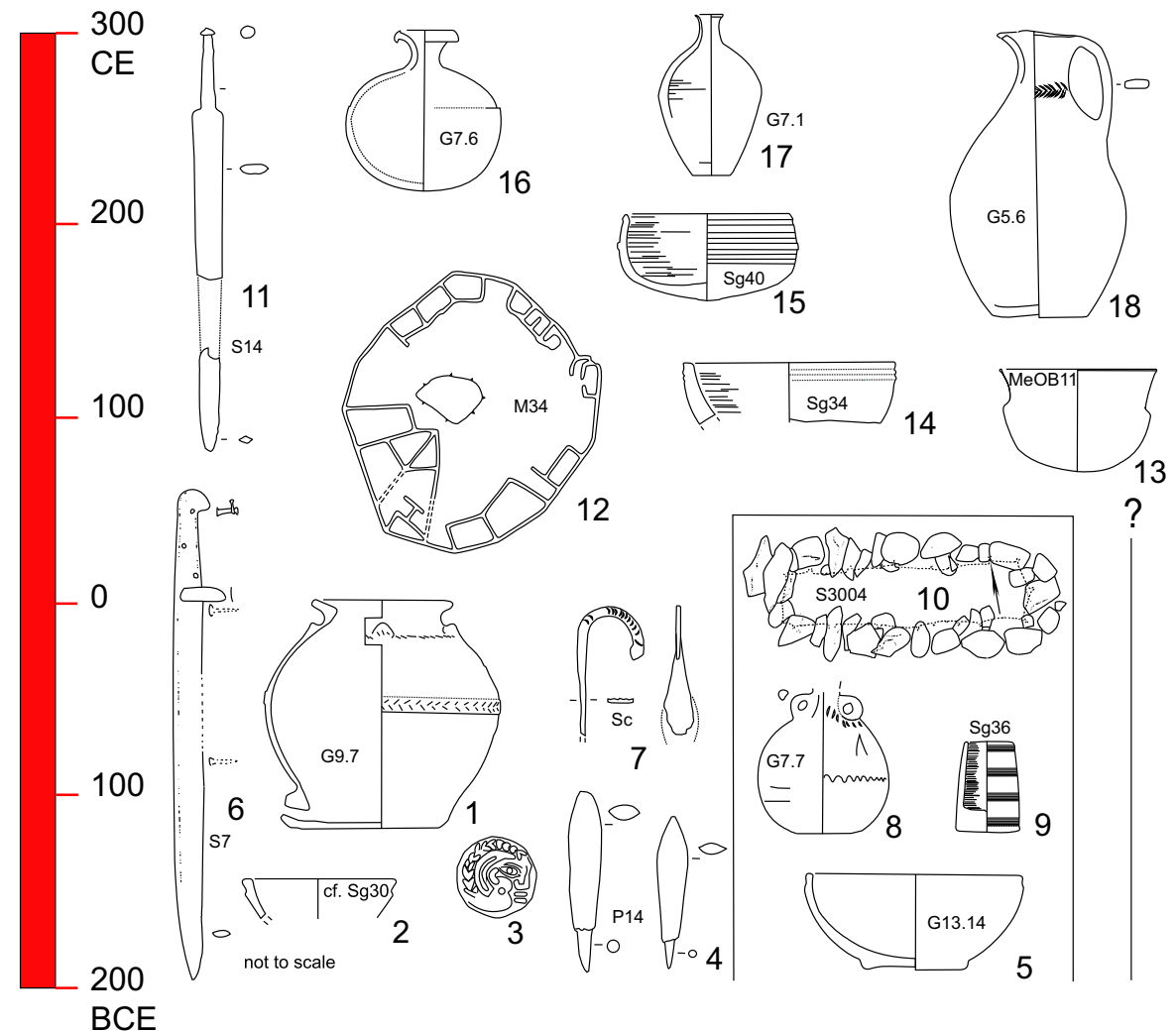

Fig. 31 .

This suggested chronology overview for the Samad LIA in Central Oman shows correspondences linked to dated finds. This chronology is not ${ }^{14} \mathrm{C}$-assisted and shows finds that date larger parts of the Samad LIA assemblage, not just isolated stray imports.

Table 10. Key dated Samad LIA attributes (cf. Fig. 31).

\begin{tabular}{|c|c|c|c|c|}
\hline No. & Description & Find class & Provenance & Evidence \\
\hline 1 & vat & G9.7 & $\mathrm{S} 3001$ & examples from M43 \\
\hline 2 & bowl & $\mathrm{cf} \mathrm{Sg} 30$ & M34 & date of M34 \\
\hline 3 & Abiel coin & - & al-Nejd & surface pottery, see above \\
\hline 5 & bowl & G13.14 & S3004 & date of S3004 \\
\hline 6 & Fe sword & S7 & Am5 & cf. swords al-Fuwayda \\
\hline 7 & ladle handle & $\mathrm{Sc}$ & S3017a & ed-Dur gr. 5156, PIR.C \\
\hline 10 & grave & S3004 & S3004 & pottery compared with that of M34 \\
\hline 11 & Fe sword & S14 & $\mathrm{S} 3032$ & cf. Dura Europos \\
\hline 12 & fort & M34 & M34 & thermoluminescence $130 \pm 150 \mathrm{CE}$ \\
\hline 13 & Ag bowl & $\mathrm{MeOB} 11$ & S10815 & not clearly datable \\
\hline 14 & stone bowl & $\operatorname{Sg} 34$ & M4304 & date of S3004 \\
\hline 15 & stone bowl & $\mathrm{Sg} 40$ & Mu1 & cf. Mouton 2008: fig. 93/6 PIR.C \\
\hline
\end{tabular}

at Samad S10 (Vogt 1984: 271) are far too high. Spread over $80,000 \mathrm{~km}^{2}$, seventy-five sites and four suspected ones show an area of distribution about as large as the present-day UAE (Yule 2014: 55, 89-92). Mouton rightly points out that we cannot just ignore them (Mouton \& Schiettecatte 2014: 77). He argues for similarity in the EIA and LIA morphology of Central Oman settlements (based on Schreiber, e.g. 2007: 277), which contrasts with 
the present writer's view presented above. A second artefactual assemblage, the PIR, known from eighteen sites mostly located in northern Oman, significantly contrasts with the Samad artefactual assemblage in different ways. According to the 'falaj mechanics', the horizontal site distribution shows five phases of falaj growth for the M42 and M43 settlements. More falaj rebuilds are probable to compare the profile photos and lateral distribution of the house ruins.

The earliest Samad LIA settlement context known for chorological reasons is arguably M4304, the pottery of which dates other early LIA grave inventories (Fig. 31 and Table 10). Downslope, fort M34 belongs to the next falaj phase (see above). Nevertheless, the available pottery from both is indistinguishable, suggesting their chronological proximity. A few more contexts and artefact classes cannot be convincingly attributed to either, but intuitively fit better in the LIA than elsewhere (see Fig. 1; Yule 2014: 56, fig. 28). The vat (Fig. 31/1) is identical to ones from house ruin M4304. Figure 31/2 shows a pottery bowl with a constricted rim, which may date to early Samad LIA and the PIR.A, if it is not a holdover from the EIA. Figure 31/3, an Abiel coin from al-Nejd, dates this site to the late first millennium BCE. Rather few locally produced artefacts are better dated and give an idea of the relative chronology. Figure 31/4 shows rare correspondences to Mouton's type $\mathrm{AE}$ arrowheads from PIR.A contexts in Mlayha. Belonging to the earliest Samad LIA funerary artefacts are those from gr. S3004 (Fig. 31/5,8-10). The deep puncture pattern of Figure 31/7 finds parallels with decorated vessels in M34 and M43. The shape of the rim-flange sword grip (Fig. 31/ 6) resembles best those from al-Fuwaydah gr. Fu12, Fu16 and Fu19 of the PIR.B. The closest comparison for the ladle handle (Fig. 31/7) is from ed-Dur area AV from G 5156 (Haerinck 2001: pl. 95/30,31; Mouton 2008: fig. 89). The sword (Fig. 31/11) finds its closest parallels in third-century CE Dura Europos (James 2004: 145, fig. 84 no. 513). Except for shallow 'gutters', swords from this context share the same size and shape. Figure 31/12 shows the plan of the fort M34 with its early pottery and thermoluminescence dating of $130 \pm 150 \mathrm{CE}$. The lathe-turned stone vase from house M4304 finds (see above) and the early PIR appears in Figure 31/14. The stone vessel (Fig. 31/15) fits best with one from PIR.C (Mouton 2008: fig. 93/7). The balsamarium (Fig. 31/16) finds its closest shape-comparison in ed-Dur chantier F of the PIR.D (2008: 131, fig. 113/8), while the other balsamarium (Fig. 31/17) finds a close comparison with another from 'Asima gr. As24 (2008: fig. 127/4). The pitcher (Fig. 31/18) is most closely related to Sigillata Afri- cana A of the first half of the third century CE (Hayes 1981: 43-44, tav. 20/10, 132/3; cf. Salomonson form A28). The vessel proportions and the position of the decoration are similar.

The different repertories of stone vessels of the two respective LIA facies also certainly point to different origins and trade partners of two LIA populations. The chorology of the EIA and LIA sites mentioned above reveal far more EIA sites (162) than those of the LIA (seventy-five: Yule 2014: 82-92 plus recent additions). A drastic reduction in the population during the LIA is a key development, the reasons for which are still imperfectly understood. The LIA newcomers brought few, if any, technical innovations with them. During the LIA, however, lathe turning comes into use for stone, possibly for metalworking, if such vessels are not imported. After a flourishing, the end of copper production after the EIA coincides with this decrease, showing a cultural-historic discontinuity. The chosen site locations of the two periods do not suggest continuity and deserve further study.

If comparisons between PIR and Samad LIA finds are rare, then imports between the two are even rarer. An Abiel coin found in the al-Nejd settlement (Fig. 19) and another recently excavated from Adam (G. Gernez, personal communication, Paris) is the first such one to be identified with certainty in a Samad LIA context in Central Oman and is also the first coin to be associated with Samad LIA pottery.

Figure 32 summarises the salient respective diagnostic finds of the EIA, PIR and Samad LIA. The basic points above include the independent nature of each of the three find assemblages under discussion. If experts have problems distinguishing them, then others with less expertise will have even more. The six find categories, pottery, metal vessels, daggers, swords, stone vessels and bangles in Figure 32 all show distinctive characteristics when juxtaposed, basically contrasting between the three assemblages.

While the PIR chronology can serve to complement and correct that in Central Oman, it cannot supplant the local dating evidence. In Mouton's reinterpretation of the similarity of EIA and LIA pottery as well as between the PIR and Samad LIA, one could hope for or expect at least one single supporting visual comparison. Aside from numerous misleading factual errors, a main difficulty is that he has no strategy to deal with heirloom artefacts and unstratified finds, as if every piece were contemporary bona fide with its context, with no closed system of find assemblages. Mouton is one of the few even to attempt to enter 


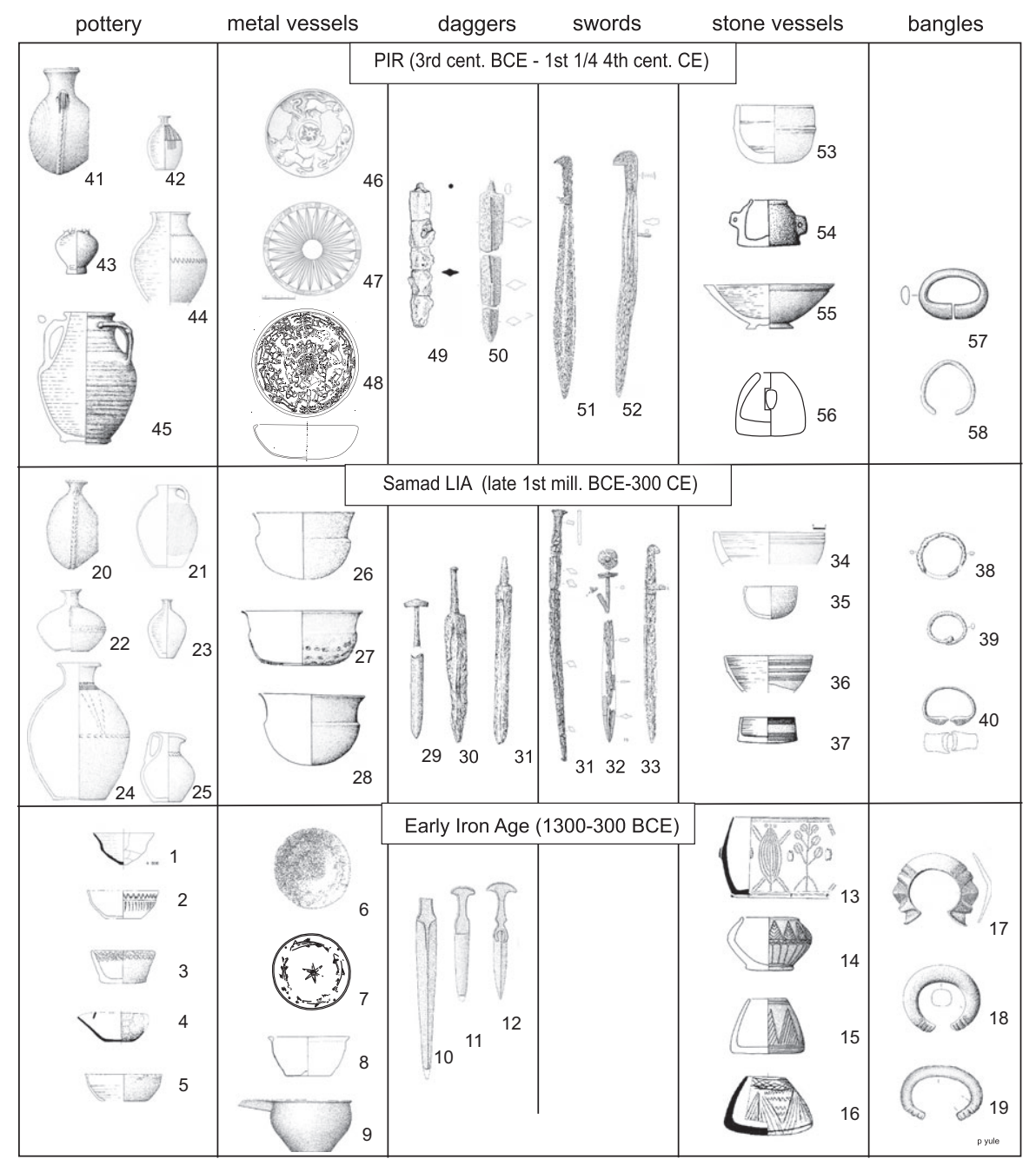

Fig. 32.

Characteristic finds of the EIA, PIR and Samad LIA generally contrast with each other. The PIR and Samad LIA, however, share a few forms.

the fluidly changing discussion of the Samad LIA, but deviations from the published documentation damage the study of the Samad LIA. His deconstruction of the LIA chronology and site dating causes more problems than it resolves: the pottery dating which results from the chorological position of the different M46 settlements must comply with the pottery sequence (Table 8).

At the end of the first millennium BCE and later the speakers of Arabic language migrated in several waves from Central and South Arabia toward the south-east. On arrival in Oman they encountered an indigenous population that may have spoken a mixture of Modern South Arabian and other Semitic languages (Yule 2014: 70-71). Perhaps old two-syllable names such as Bawshar, Bid Bid,

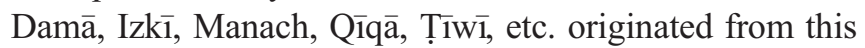
population. The subsequent migrant population imported the languages spoken from their homes, for example Azdi Arabic to Oman (Sharkawi 2008). Defined by means of the criteria outlined above, we have good reason here to consider that two different sequential cultural facies collided.

Differentiating the pottery of the EIA and Samad LIA can be brought further than Schreiber achieved with survey methods. One approach is by means of the excavation of the pottery from single-period sites. A means of fixing the earliest and latest Samad LIA contexts in absolute years would be highly desirable. Moreover, Schreiber writes that most of the Samad LIA finds lie early within its time bracket (2007: 110). In the present writer's opinion, this also holds for the LIA excavated graves in Samad and al-Moyassar as well as for the four PIR phases (Mouton \& Schiettecatte 2014: 53). Intuitively, we estimate that the 
beginning of the Samad LIA may predate dwelling M4304 and we have only one thermoluminescencete from the M34 fort, which is somewhat later than this. There is no compelling reason to insist that M4304 is the very first settlement of the Samad LIA, but it is early in that sequence. The terminal date of M34 is similarly early in the LIA sequence. There are few anchoring points with the PIR. Thus the overview in Figure 32 uses relatively secure dating comparisons that are in fact few in number.

The destruction of archaeological sites in Central Oman and elsewhere is accelerating. Within the past twenty years and in the future al-Moyassar M34, M43, Samad S1, S7 and the Șūr 'hill fort' and Tịwī TW0002 have been or will be obliterated as a result of encroachment, vandalismespecially by dune buggies and motorcycles-and stone exploitation combined with weathering. The unprotected J. Sunsunah and al-Nejd settlements are still in somewhat good condition but they will soon be encroached upon. Weisgerber once metaphorically described the forty-four hills of M43 as beads on a necklace. Since then the 'string' has broken and only about five seem to be extant. Furthermore, the architecture of Samad S7 is completely destroyed and is known mostly through surface sherds. In the central part of the country thirty years of population growth, archaeology and prosperity have done more damage than the preceding 2000 years.

In 2011 the present writer's search at Izkī for Samad LIA finds dated in the centuries immediately following $300 \mathrm{CE}$ was unsuccessful, and the likelihood of finding such remains grows less probable than previously thought. For a site like TW0002, this means that there was only a modest chance of repopulation until the Ya ăriba period when the population recovered somewhat. In any case, to judge from this context the two populations had different survival strategies. Notwithstanding a lack of radiocarbon dating, there probably were few or no populations in the fourth to sixth centuries CE because of mega-droughts (Fleitmann et al. 2011). This fits better with the decline in south-east Arabia at this time described by Kennet than the prosperity advocated by Wilkinson (Yule 2009: 86), but if one were to systematically search the wadi flanks, new sites might possibly appear which would change our demographic view of Central Oman.

Building on Weisgerber's chronology, one can maintain a late EIA III date for M42 and an early Samad LIA date for M4304 and M34. PIR.A artefact parallels, radiocarbon and thermoluminescence might still raise the absolute terminus for the inception of the Samad LIA period-a worthy research priority for the future.
By articulating the attributes of the Samad LIA and discussing and providing visual materials on them, this in effect valorises this period, its sites and its culture.

\section{Acknowledgements}

I am grateful to the Deutsches Bergbau-Museum for supporting my Oman research in the museum years after fieldwork was completed. The Interdisciplinary Centre for Scientific Computing of Heidelberg University enabled a visit to Oman in December of 2014 and again in 2015.

Reinhardt Stupperich contributed the section on the imported Roman bronze vessel handles. Lorenz Korn and Jutta Häser advised me on the site recording at TW0002. I thank Andreas Tillmann who advised me on his excavations of 1981. Michel Mouton criticised a version of my text. Ulrich Schüßler kindly granted permission to cite Cordelia Rösch's unpublished thesis on the chemistry of the beads. The Director General of the Department of Archaeology of the Ministry of Heritage and Culture, Hassan al-Lawati, is thanked for enabling my visit to Oman in April 2014, providing quarters in 2015 and for publication permissions. Negar Abdali (Heidelberg) assisted in the field in documenting the settlement site of Qariyat al-Saih in Wādī Mahram and in readying the manuscript. Philip Koch kindly optimised the difficult scans of aerial photographs of the Tîwi and Mahram sites.

Image sources: Figs. 1, 2/1, 2/3-5, 2/2, 4, 6/1, 6/2, 6/ 4, 8, 12, 16, 18, 20 (top), 25, 29 Yule; Figs. 3/1-8, 5/a-e after Mouton 2008 (redrawn); Fig. 2/2 after Schreiber \& Häser 2004: 324, fig. 8; Fig. 2/6 after Haerinck 2001: 13; Figs. 5/P10-P19.3, 6/3, 11, 13, 31 I. Blome; Fig. 6/5 after Marshall 1951, III: pl. 187/6; Fig. 6/6 after Pfrommer 1987: pl. $62.77=$ Schmidt 1957: pl. 68.1; Fig. 7 Kelber; Fig. 9 German Mining Museum, Bochum; Figs. 10, 15 A. Weisgerber; Fig. 14 after A. Tillmann; Figs. 17, 20 (bottom), 21, 23, 26, 27, 28 Google Earth; Fig. 19 A. Abar; Fig. 22 OM81 81 003; Fig. 24 L. Korn; Fig. 30 BKS OM85 44 053; Fig. $31=$ Table 10.

Fig. 32/1: Bawshar gr. B6; 2 M4302; 3 gr. S21113; 4 Bawshar gr. B51; 5 gr. S2113; 6 Ibrī/Selme DA 3785; 7 Selme DA 5655; 8 Qarn Bint Sa'ūd; 9 Selme DA 3766; 10 Selme DA 3524; 11 Selme DA 8831; 12 Selme DA 3620; 13 Rumaylah; 14 Selme DA 3615; 15 Selme DA 3614; 16 Bawshar gr. B42; 17 Selme DA 3649; 18 Selme DA 3693; 19 Selme DA 3699; 20 gr. S10832; 21 gr. S2137/2; 22 gr. S2104; 23 gr. S2138-; 24 gr. S10823; 25 gr. S101124; 26 gr. Bu5; 27 gr. S101124; 28 gr. S10815; 29 gr. S2104; 30 gr. Am5; 31 gr. S2615; 32 gr. S10823; 33 
gr. S2137/2; 34 gr. Am5; 35 M4304; 36 gr. S2151; 37 gr. S3004; 38 gr. S3018; 39 gr. S101123; 40 gr. S3018; 41 gr. Fu19; 42 gr. Fu7; 43 gr. Fu7; 44 gr. Fu23; 45 gr. Fu12; 46 gr. Bar1; 47 gr. Fu9; 48 gr. Fu11; 49 ed-Dur; 50 gr. Fu12; $\mathbf{5 1}$ gr. Fu16; 52 gr. Fu19; 53 gr. Bar1; 54 gr. Fu9; 55 gr. Fu13; 56 Mlayḥa PIR.A; 57 gr. Fu9; 58 ed-Dur F.
Table sources: 1. data: Yule 2001a, I: 163, table 6/13; 2. data: Mouton 2008: 35; Yule 2014: 62-67; 3. data: Yule; 4. data: Rösch 1996; 5. data: De Waele 2007: 300; 6. data: Rösch \& Yule; 7. Weisgerber \& Tillmann unpublished; 8-10. Yule.

\section{References}

Arnold, W. \& Sima, A. 2011. Das MaysirSpiel im Mahra-Land. Ein Text im MehriDialekt von Hawf erzählt von 'Askari Sa'd. Pages 421-427 in Musall, F. \& alMudarris, A. (eds.), Im Dialog Bleiben. Sprache und Denken in den Kulturen des Vorderen Orients: Festschrift für Raif Georges Khoury. Wiesbaden:

Harrassowitz.

Benoist, A. 2000. La céramique de l'âge du fer en Péninsule d'Oman (1350-300 av. J.C.). Unpublished $\mathrm{PhD}$ thesis, Université de Paris.

Benoist, A., Bernard, V., Schiettecatte, J. \& Skorupka, M. 2013. Architecture et stratigraphie de Bithnah-24. Pages 40-54 in Benoist, A., Bernard, V., Le Carlier, C. et al. (eds.), La vallée de Bithnah au cours de l'Age du Fer. (British Foundation for the Study of Arabia Monograph, 14) (BAR International Series, 2510). Oxford: Archaeopress.

David, H. 1991. A First Petrographic Description of the Soft Stone from Shimal. Pages 175-178 in Schippmann, K., Herling, A. \& Salles, J.-F. (eds.), Golf-Archäologie, Mesopotamien, Iran, Kuwait, Bahrain, Vereinigte Arabische Emirate und Oman. Buch am Erlbach: Leidorf.

Deimel, M. 1982. Die Bronzekleinfunde vom Magdalensberg. Kärntner Museumsschriften. Vol. 71 Archäologische Forschungen zu den Grabungen auf dem Magdalensberg, Vol. 9. Vienna.

De Waele, A. 2007. The Beads of ed-Dur (Umm al-Qaiwain). Proceedings of the Seminar for Arabian Studies 37: 297-308.

Dostal, W. 1968. Zur Megalithenfrage in Südarabien. Pages 53-61 in Graf, E. (ed.), Festschrift Werner Caskel. Leiden: Brill.

Eggers, H.J. 1949-50. Lübsow, ein germanisches Fürstengrab der älteren römischen Kaiserzeit. Prähistorische Zeitschrift 34-35/2: 58-111.
Eggers, H.J. 1951. Der römische Import im freien Germanien. Atlas der Urgeschichte 1. Hamburg.

Eggert, K. 2001. Prähistorische Archäologie: Konzepte und Methoden. Tübingen: A. Francke Verlag.

Fleitmann, D. et al. 2011. Megadroughts at the dawn of Islam recorded in a stalagmite from Northern Oman. American Geophysical Union Fall Meeting, San Francisco, Mineralogical Magazine. www.minersoc.org, Goldschmidt Conference Abstracts, 853.

Haerinck, E. 2001. Excavations at ed-Dur (Umm al-Qaiwain, United Arab Emirates). Vol. 2. The Tombs. Leuven: Peeters.

Haerinck, E. 2003. Review of Yule 2001a. American Journal of Archaeology. 107: 301-302.

Harrower, M., Senn, M. \& McCorriston, J. in press. Tombs, Triliths and Oases: Spatial Analysis of the Arabian Human Social Dynamics (AHSD) Project, Archaeological Survey 2009-2010. Journal of Oman Studies: 145-151.

Hassel, J. 1997. Alabaster Beehive-Shaped Vessels from the Arabian Peninsula: Interpretations from a Comparative Study of Characteristics, Contexts and Associated Finds. Arabian Archaeology and Epigraphy 8: 245-281.

Hayes, J. 1981. Atlante delle Forme Ceramiche I - Ceramica Fine Romana nel Bacino Mediterraneo (Medio e Tardo Impero). Enciclopedia dell'Arte Antica Classica e Orientale 1. Rome.

Healey, J. \& Seray, H. 1999. Aramaic in the Gulf: Towards a Corpus. Aram 11: $1-14$.

al-Jahwari, N. 2011. A Late Iron Age Settlement in Mahleya, Oman. Journal of Oman Studies 17: 73-100.

James, S. 2004. Excavations in Dura Europos 1928-1937 Find Report VII. The Arms and Armour. London: Oxbow.
Jasim, S. 2012. The Necropolis of Jebel alBuhais. Sharjah: Department of Culture and Information.

Kenner, H. 1961. Die Kleinfunde römischer Art. Pages 74-167 in Egger, R., Die Ausgrabungen auf dem Magdalensberg 1958 und 1959. Carinthia 1: 151.

Kennet, D. 2007. The Decline of Eastern Arabia in the Sasanian Period. Arabian Archaeology and Epigraphy 18: 86-122.

Korn, L., Häser, J., Schreiber, J., Gangler, A. et al. 2004. Tiwi, Ash Shab and Wadi Tiwi: the Development of an Oasis on the North-eastern Coast of Oman. Journal of Oman Studies 13: 57-90.

Kroll, S. 1998. Lizq. In Mouton, M. \& Carrez, F., Assemblage céramique des sites de l'Age du fer de la péninsule d'Oman. (= Documents d'archéologie de l'Arabie, 1). Lyon. (CD-ROM).

Kroll, S. 2013. The Early Iron Age Lizq Fort, Sultanate of Oman (Translated and revised by Paul Alan Yule). Zeitschrift für Archäologie außereuropäischer Kulturen 5: 159-220.

Lombard, P. 1985. L'Arabie Orientale à l'Age du Fer. Unpublished PhD thesis, Université Paris I.

Macdonald, M. 2010. The 'Abiel' Coins of Eastern Arabia: A Study of the Aramaic Legends. Pages 403-547 in Huth, M. \& van Alfen, P. (eds.), Coinage of the Caravan Kingdoms. (Numismatic Studies, 25). New York: American Numismatic Society.

Magee, P. 2003. New Chronometric Data Defining the Iron Age II in Southeastern Arabia. Proceedings of the Seminar for Arabian Studies 33: 1-12.

Marshall, J. 1951. Taxila. An Illustrated Account of Archaeological Excavation Carried Out at Taxila Under the Orders of the Government of India Between the Years 1913 and 1934. Cambridge: Cambridge University Press. 
Mouton, M. 1990. Les Pointes de Flèches en Fer des Sites Préislamiques de Mleiha et ed-Dur, E.A.U. Arabian Archaeology and Epigraphy 1: 88-103.

Mouton, M. 2008. La péninsule d'Oman de la fin de l'âge du fer au début de la période sasanide (250 av.-350 ap. J.-C.). (Society for Arabian Studies, Monograph 6). (BAR International Series, 1776). Oxford: Archaeopress.

Mouton, M. \& Schiettecatte, J. 2014. In the Desert Margins. The Settlement Process in Ancient South and East Arabia. Rome: 'L'Erma' di Bretschneider.

Pfrommer, M. 1987. Studien zu alexandrinischer und großgriechischer Toreutik frühhellenistischer Zeit. (Deutsches Archäologisches Institut, Archäologische Forschungen 16). Berlin.

Phillips, C. 2010. Iron Age Chronology in South East Arabia and New Data from Salut Sultanate of Oman. Pages 71-79 in Avanzini, A. (ed.), Eastern Arabia in the First Millennium BC. (Arabia Antica, 6). Rome: 'L'Erma' di Bretschneider.

Ploquin, A., Orzachowsky, S. \& Briand, B. 1999. Paléométallurgie à Mleiha: une première approche. Pages 71-190 in Mouton, M. (ed.), Mleiha I, Environnement, stratégies de subsistence et artisanats. (Travaux de la Maison de l'Orient, 29) Lyon: Diffusion de Boccard.

Potts, D.T. 1991. The Pre-Islamic Coinage of Eastern Arabia. (Carsten Niebuhr Institute Publications, 14). Copenhagen: Museum Tusculanum Press.

Potts, D.T. 1992. The Arabian Gulf in Antiquity. (2 volumes). Oxford: Oxford University Press.

Potts, D.T. 1994. Supplement to Pre-Islamic Coinage of Eastern Arabia. (Carsten Niebuhr Institute Publications, 16). Copenhagen: Museum Tusculanum Press.

Rösch, C. 1994. Präislamische Schmuckperlen aus dem Sultanat Oman - Mineralogischmaterialkundliche Untersuchungen. Unpublished $\mathrm{PhD}$ thesis, Inst. für Mineralogie der Universität Würzburg. URL: http://archiv.ub.uni-heidelberg.de/ propylaeumdok/volltexte/2009/305

Rösch, C., Hock, R., Schüssler, U., Yule, P. \& Hannibal, A. 1997. Electron Microprobe Analysis and X-ray Diffraction Methods in Archaeometry: Investigations on PreIslamic Beads from the Sultanate of
Oman. European Journal of Mineralogy 9: 763-783.

Rutten, K. 2009. Het Aardewerk van ed-Dur (Umm Al-Qaiwain, V.A.E.) uit de late $1^{\text {ste }}$ eeuw v. Tot de Vroege $2^{\text {de }}$ eeuw n. Chr. Unpublished $\mathrm{PhD}$ thesis, University of Gent. URL: https:// independent.academia.edu/KatrienRutten

Schmidt, E. 1957. Persepolis II Contents of the Treasury and other Discoveries. (Oriental Institute Publications, 69). Chicago: Oriental Institute, University of Chicago.

Schreiber, J. 2005. Archaeological Survey at Ibrā' in the Sharqiyah, Sultanate of Oman. Proceedings of the Seminar for Arabian Studies 35: 255-270.

Schreiber, J. 2007. Transformationsprozesse in Oasensiedlungen Omans. Die vorislamische Zeit am Beispiel von Izki, Nizwa und dem Jebel Akhdar. Unpublished PhD thesis, Munich. URL: http://edoc.ub.uni-muenchen.de/7548/1/ Schreiber_Juergen.pdf

Schreiber, J. 2010. The Iron I-Period in Southeastern Arabia a View from Central Oman. Pages 81-90 in Avanzini, A. (ed.), Eastern Arabia in the First Millennium BC. (Arabia Antiqua, 6). Rome: 'L'Erma' di Bretschneider.

Schreiber, J. \& Häser, J. 2004. Archaeological Survey at Țīwī and its Hinterland (Central Oman). Proceedings of the Seminar for Arabian Studies 34: 319-29.

Sedov, A. 2008. The coins from Sumharam: The 2001A-2004A Seasons. Pages 277316 in Avanzini, A. (ed.), A Port in Arabia between Rome and the Indian Ocean (3rd c. $B C-5$ th c. $A D$ ). (Khor Rori Report, 2). Rome: 'L'Erma' di Bretschneider. al-Shaḥrī, A.A.M. 1991. Grave Types and 'Triliths' in Dhofar. Arabian Archaeology and Epigraphy 2/3: 182-195.

al-Sharkawi, M. 2008. Pre-Islamic Arabic. Pages 689-699 in Encyclopedia of Arabic Language and Linguistics. Vol. 3. Leiden: Brill.

Tillmann, A. 1981. Die Burg Maysar-34. Pages 233-235 in Weisgerber, G., Mehr als Kupfer in Oman. Ergebnisse der Expedition 1981. Der Anschnitt 33/5-6: 174-263.

van Alfen, P. 2010. A Die Study of the 'Abiel' Coinage of Eastern Arabia. Pages 549-592 in Huth, M. \& van Alfen, P. (eds.), Coinage of the Caravan Kingdoms. (Numismatic Studies, 25). New York: American Numismatic Society.
Vogt, B. 1984. 1st Mill. B.C. Graves and Burial Customs in the Samad Area (Oman). Pages 271-279 in Boucharlat, R. \& Salles, J-F. (eds.), Arabie Orientale, Mésopotamie et Iran Méridional. (Mémoire 37). Paris: Éditions recherche sur les civilisations.

Weisgerber, G. 1980. ...und Kupfer in Oman. Der Anschnitt. 32/2 -3: 62-110.

Weisgerber, G. 1981. Mehr als Kupfer in Oman. Ergebnisse der Expedition 1981. Der Anschnitt 33/5-6: 174-263.

Weisgerber, G. 1982. Aspects of Late Iron Age Archaeology in Oman: The Samad Civilizations. Proceedings of the Seminar for Arabian Studies 12: 81-93.

Weisgerber, G. 2003. The Impact of the Dynamics of Qanats and Aflaj on Oases in Oman Comparisons with Iran and Bahrain, Internationales Frontinus-Symposium. Pages 61-97 in Wasserversorgung aus Qanaten - Qanate als Vorbilder im Tunnelbau 2.-5. Oktober 2003. Walferdange/Luxemburg: FrontinusGesellschaft.

Wagner, G. \& Yule, P. in press. Thermoluminescence Dating of Ceramics from Oman. In Yule, P. (ed.), Archaeological Research in the Sultanate of Oman. Der Anschnitt.

Wheeler, M. 1954. Archaeology from the Earth. Harmondsworth: Pelican.

Wielowiejski, J. 1985. Die spätkeltischen und römischen Bronzegefäße in Polen. Bericht der Römisch-Germanischen Kommission: 123-320.

Wilkinson, J. 1983. The Origins of the Aflāj of Oman. Journal of Oman Studies 6/1: 177194.

Yule, P. 1998. Pottery of the Early Iron Age from al Maysar M43 (Sultanate of Oman). In Mouton, M. \& Carrez, F. (eds.), Assemblages céramiques des sites de l'Age du Fer de la péninsule d'Oman. Lyon. CD publication.

Yule, P. 1999a. 'Amlah, al-Zahirah (Sultanat Oman) - späteisenzeitliche Gräberfelder 1997. Pages 119-186 in Yule, P. (ed.), Studies in the Archaeology of the Sultanate of Oman. (Orient-Archäologie 2). Rahden/ Westf:: Marie Leidorf.

Yule, P. 1999b. The Samad Period in the Sultanate of Oman. Iraq 61: 121-146. URL: http://archiv.ub.uni-heidelberg.de/ propylaeumdok/volltexte/2010/476/

Yule, P. 2001a. Die Gräberfelder in Samad alShan (Sultanat Oman). Materialien zu 
VALORISING THE SAMAD LIA

einer Kulturgeschichte. (Deutsches Archäologisches Institut, OrientAbteilung, Orient-Archäologie, 4). Rahden/Westf.: Marie Leidorf.

Yule, P. 2001b. Recently Discovered Bronze Bowls from 'Amlah, al Zahīrah Province and the Late Pre-Islamic Cultures of Oman. Baghdader Mitteilungen 32: 255287.

Yule, P. 2001c. A Bronze Bowl from the Back Country of the Sultanate of Oman. Pages 494-509 in Mayer, J-W., Novák, M. \& Pruß, A. (eds.), Festschrift W. Orthmann. Frankfurt/Main.

Yule, P. 2009. Sasanian Presence and Late Iron Age Samad in Central Oman, some Corrections. Pages 69-90 in Schiettecatte, J. \& Robin, C. (eds.), L'Arabie à la veille de l'Islam. Bilan clinique. Paris: Boccard.
Yule, P. 2013. Late Pre-Islamic Oman: The Inner Evidence - The Outside View. Pages 13-33 in Hoffmann-Ruf, M. \& al-Salami, A. (eds.), Studies on Ibadism and Oman, Oman and Overseas. Vol. 2. Hildesheim: Olms.

Yule, P. 2014. Cross-Roads; Early and Late Iron Age South-Eastern Arabia.

(Abhandlungen Deutsche OrientGesellschaft, 30). Wiesbaden: Harrassowitz.

Yule, P. in press. Interdisciplinary Nottingham Trent-Heidelberg University Joint Expedition in Izki, 09 February-14 March 2011. In Yule, P (ed.), Archaeological Research in the Sultanate of Oman. Der Anschnitt.

Yule, P. \& Weisgerber, G. 1988. Samad ashShan Excavation of the Pre-Islamic Cemeteries Preliminary Report 1988. Bochum. URL: http://archiv.ub.uni- heidelberg.de/propylaeumdok/volltexte/ 2010/470/

Yule, P. \& Weisgerber, G. 1999. Report on the 1996 Season of Excavation in the Sultanate of Oman. OrientArchäologie 2: 97-117.

Yule, P. \& Weisgerber, G. 2001. The Metal Hoard from 'Ibri/Selme, Sultanate of Oman. (Prähistorische Bronzefunde, 20/7). Stuttgart: Steiner.

Yule, P. \& Weisgerber, G. in press, a. Al-Wāsit Tomb W1 and other Sites, Materials for a Definition of the Second Half of the 2nd Millennium BCE. In Yule, P. (ed.), Archaeological Research in the Sultanate of Oman. Der Anschnitt.

Yule, P. \& Weisgerber, G. in press, b. The Cemetery at al-Akhdiar near Samad alShān in the Sharqìya (Oman). Der Anschnitt. 